\title{
REPUBLIC OF ARMENIA \\ PROGRAMMATIC FISCAL WORK
}

SUPPORTING EFFECTIVE FISCAL MANAGEMENT

June 20, 2016 


\section{Standard Disclaimer:}

This volume is a product of the staff of the International Bank for Reconstruction and Development/ The World Bank. The findings, interpretations, and conclusions expressed in this paper do not necessarily reflect the views of the Executive Directors of The World Bank or the governments they represent. The World Bank does not guarantee the accuracy of the data included in this work. The boundaries, colors, denominations, and other information shown on any map in this work do not imply any judgment on the part of The World Bank concerning the legal status of any territory or the endorsement or acceptance of such boundaries.

\section{Copyright Statement:}

The material in this publication is copyrighted. Copying and/or transmitting portions or all of this work without permission may be a violation of applicable law. The International Bank for Reconstruction and Development/ The World Bank encourages dissemination of its work and will normally grant permission to reproduce portions of the work promptly.

For permission to photocopy or reprint any part of this work, please send a request with complete information to the Copyright Clearance Center, Inc., 222 Rosewood Drive, Danvers, MA 01923, USA, telephone 978-750-8400, fax 978-750-4470, http://www.copyright.com/.

All other queries on rights and licenses, including subsidiary rights, should be addressed to the Office of the Publisher, The World Bank, 1818 H Street NW, Washington, DC 20433, USA, fax 202-522-2422, e-mail pubrights@worldbank.org. 


\section{CURRENCY EQUIVALENTS}

(Exchange Rate as of June 20, 2016)

\section{Currency Unit Armenian Dram \\ US\$1.00 AMD478}

Weights and Measures: Metric System

\begin{tabular}{llll}
\multicolumn{2}{c}{ ABBREVIATIONS AND ACRONYMS } \\
BEEPS & $\begin{array}{l}\text { Business Environment and Enterprise } \\
\text { Performance Survey }\end{array}$ & IMF & International Monetary Fund \\
CBA & Central Bank of Armenia & ILSS & Integrated Living Standard Survey \\
CIS & Commonwealth of Independent States & MoF & Ministry of Finance \\
CPS & Country Partnership Strategy & NSS & Non-Performing Loan \\
DPO & Development Policy Operations & PER & Public Expenditics Service of Armenia \\
DSA & Debt Sustainability Analysis & PIM & Public Investment Management \\
ECA & Europe and Central Asia & PPP & Public-Private Partnership \\
FDI & Foreign Direct Investment & PSRC & Public Services Regulatory Committee \\
GDP & Gross Domestic Product & YTPP & Yerevan Thermal Power Plant \\
GoA & Government of Armenia & &
\end{tabular}

Vice President: Cyril Muller

Country Director: Mercy Timbon

Country Manager: Laura Bailey

Practice Director: Satu Kahkonen

Practice Manager: Miria Pigato

Program Leader: Rashmi Shankar

Task Team Leader: $\quad$ Gohar Gyulumyan, Rashmi Shankar 


\section{CONTENTS}

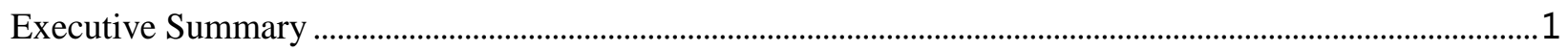

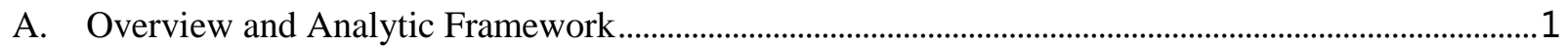

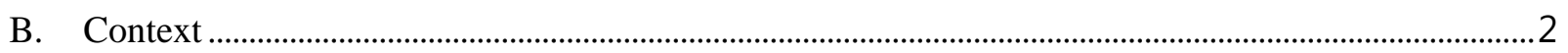

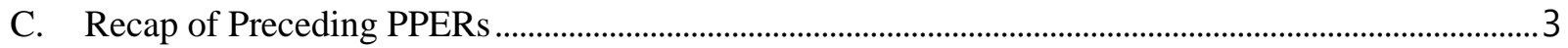

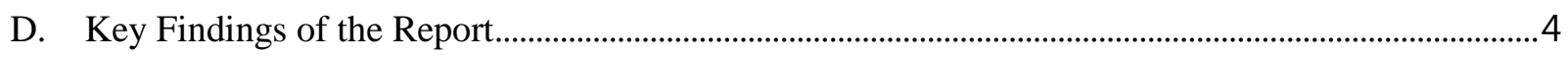

Chapter 1. Macroeconomic and Fiscal Challenges .............................................................................................. 11

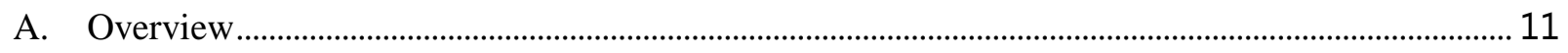

B. Benchmarking the Government's Performance ….................................................................................. 13

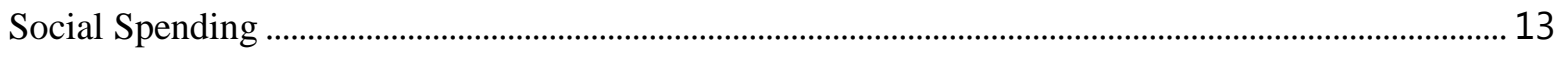

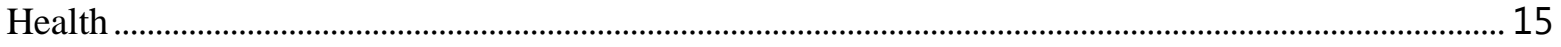

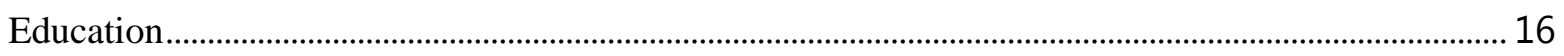

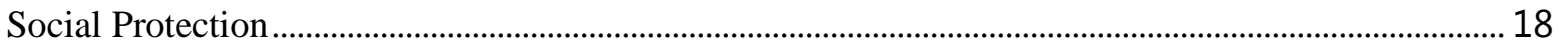

Capital Spending ............................................................................................................................ 19

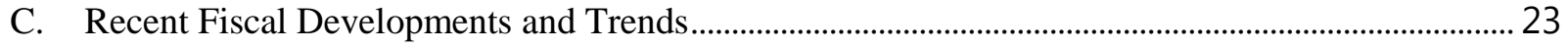

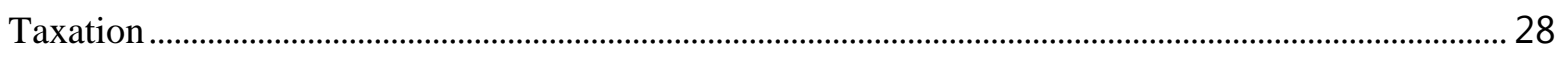

Chapter 2: Quasi-Fiscal Pressures in the Energy Sector..................................................................................... 32

A. Financial Condition of the Power Sector and Potential Fiscal Implications ...................................... 32

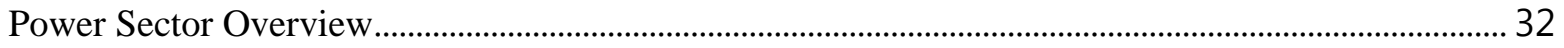

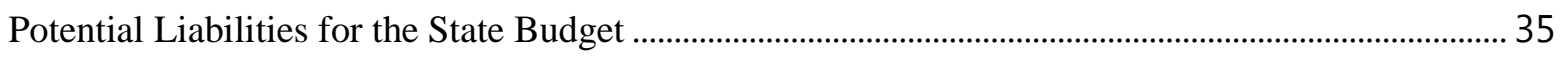

B. Reasons Behind the Deterioration of the Financial Condition of the State Power Companies....... 37

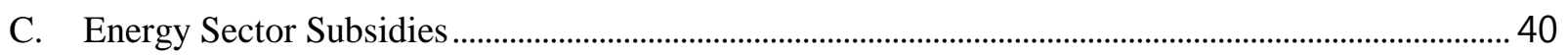

D. Fiscal Cost of New Power Sector Investment ............................................................................................ 40

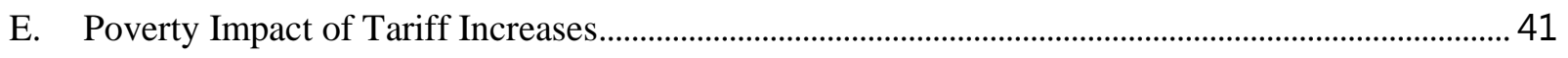

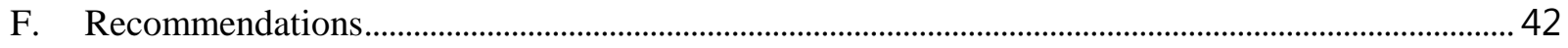

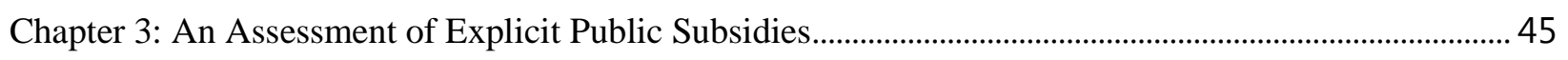

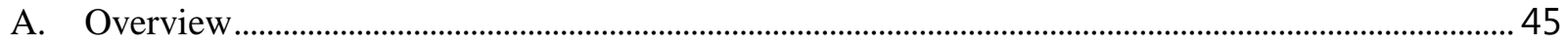

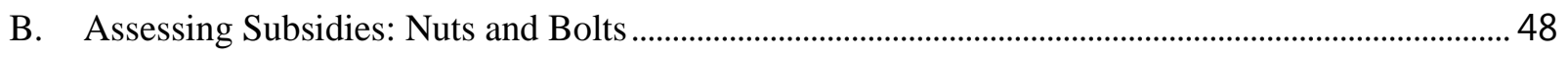


Assessing Subsidy Performance Based on Ex-Ante Objectives ............................................................... 48

Strengthening Monitoring and Evaluation and (Across-the-Board) Public Oversight Functions ....... 48

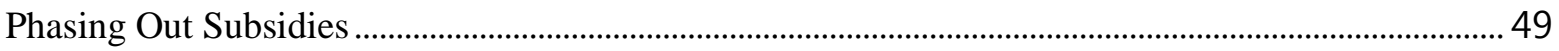

Built-In Incentives to Improve Equity and Performance at the Provider Level ...................................... 49

C. An Analysis of Subsidies in Selected Sectors ..................................................................................... 50

Railway (Brief Assessment of the Armenian Railways Concession) …………...................................... 50

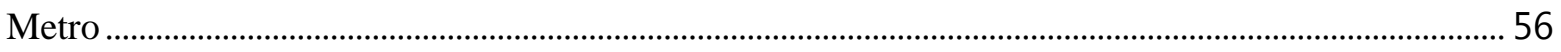

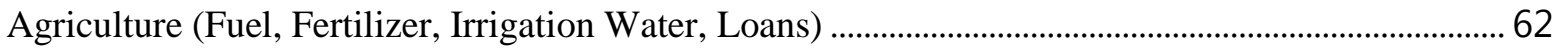

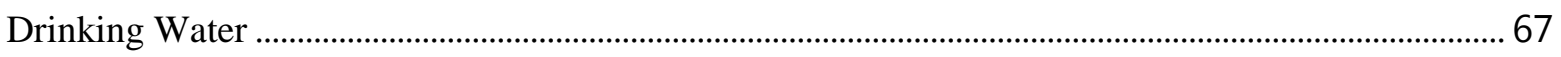

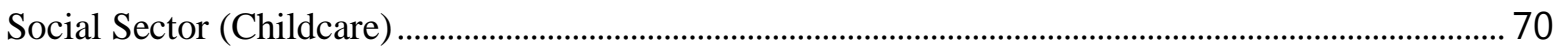

D. Summary of the Options and Recommendations................................................................................... 74

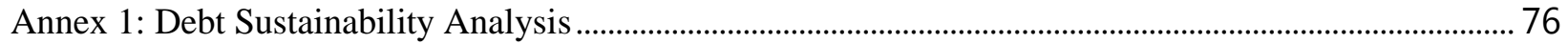

Annex 2: Underlying Assumptions of Financial Models and Forecasts of State-Owned Power Companies 78

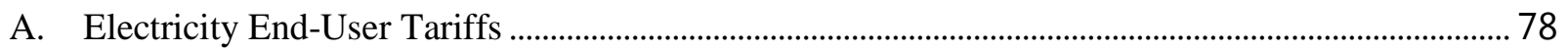

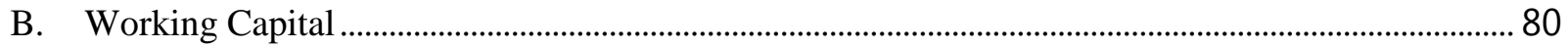

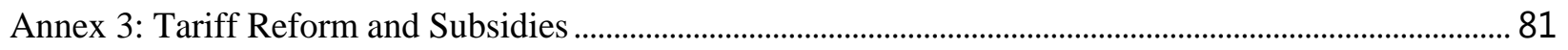

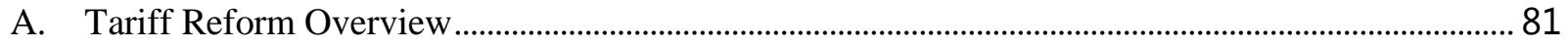

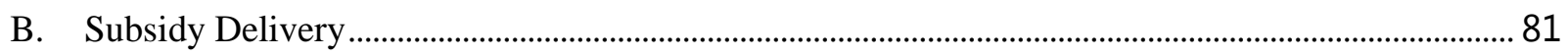

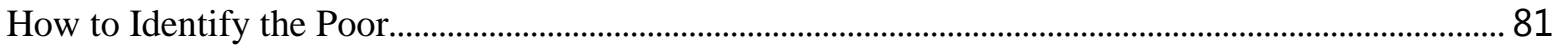

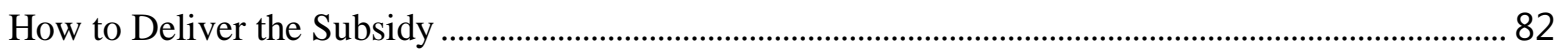

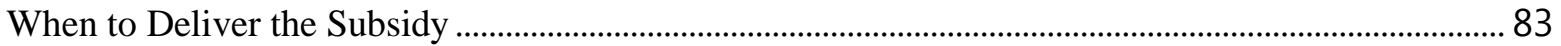

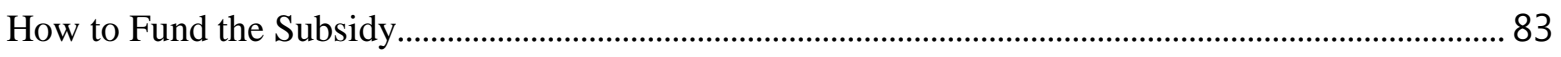

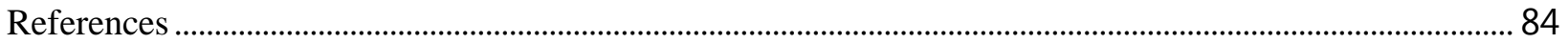




\section{FIGURES}

Figure 1. Government Spending in the Social Sectors (\% GDP)...................................................... 13

Figure 2. Selected Performance Indicators: Deviation from Group Average .......................................... 14

Figure 3. Efficiency Scores, Total Health Spending, and Share of Private Sector Health Spending ......... 16

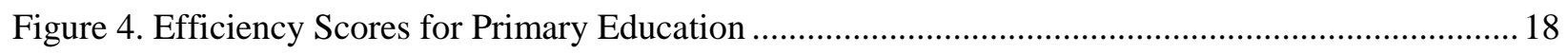

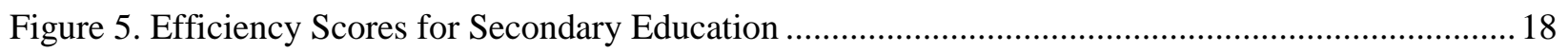

Figure 6. Efficiency of Capital Spending in a Selection of ECA and EU Countries: Overall Quality of

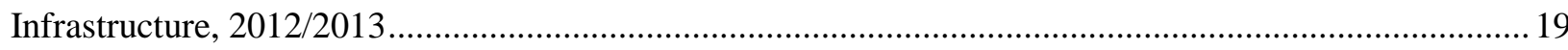

Figure 7. Efficiency of Capital Spending in a Selection of ECA and EU Countries: Quality of Roads,

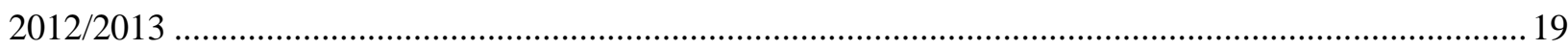

Figure 8. Correlations between Cyclical Components of Real GDP and Government Spending, 2005-2013

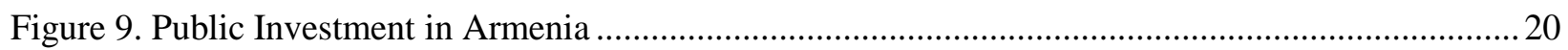

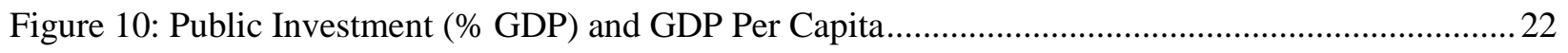

Figure 11: Response to 1 percent of GDP Increase in Public Investment ..............................................22

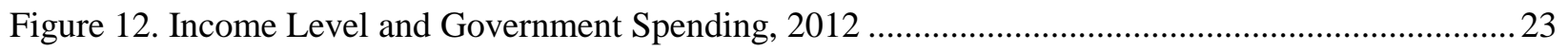

Figure 13. Expenditures, Revenues, and the Fiscal Deficit (\% GDP) .................................................25

Figure 14: Central Government Expenditures by Economic Classification, 2008-2015 ........................25

Figure 15: Central Government Expenditures by Function, 2008-2015 ............................................25

Figure 16. Central Government Spending (million AMD) and Deviation from Budgeted Amounts (\%).. 27

Figure 17. Capital Adjustment by Type of Expenditure (left panel) and Sector (right panel), 2009/2014.27

Figure 18. Top 10 Obstacles to Doing Business in Armenia, 2013 .....................................................29

Figure 19. Percent of Firms Perceiving Tax Rates (left panel) and Tax Administration (right panel) as an

Obstacle to Doing Business in Armenia, ECA, and the World ............................................................30

Figure 20. Ease of Paying Taxes (time and frequency) and Distance to Frontier in Armenia, 2006-201531

Figure 21. Armenia's Power Sector Structure ................................................................................. 33

Figure 22. An Increase in Energy Expenditure as a Share of Total Household Expenditure would Affect

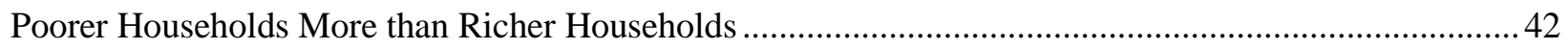

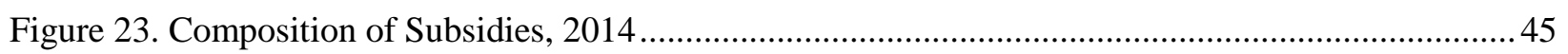

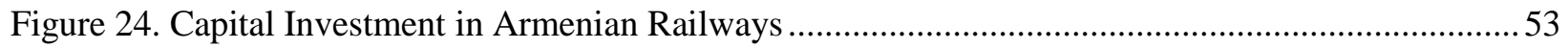

Figure 25. Freight Traffic (right panel) and Passenger Traffic (left panel) ..........................................53

Figure 26. Concession Fee-Subsidy Balance …............................................................................5

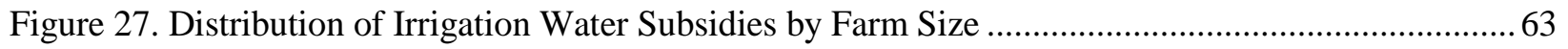

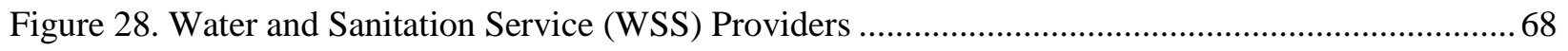

Figure 29. Service Provider Operating and Capital Expenditures versus Tariff Revenue (2012) ..............70

Figure 30. Potential Savings from Moving to Family-based Childcare................................................. 73

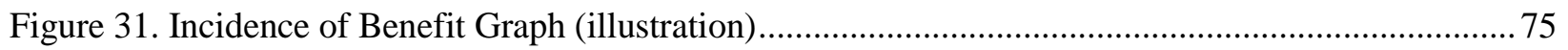




\section{TABLES}

Table 1. Quasi-Fiscal and Fiscal Liabilities (stock, as of end-2014) .................................................... 6

Table 2. Key Findings and Policy Recommendations for Consideration ................................................ 7

Table 3. Selected Outcome Indicators for Social Sectors, Latest Available Observation ......................... 15

Table 4: Central Government Tax Arrears, 2012-2015 (billion AMD) ....................................................2 28

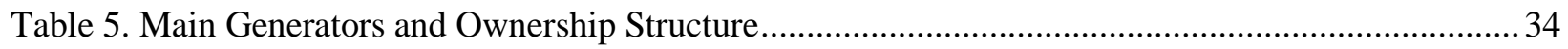

Table 6. Aggregate Financing Gap of State-Owned Power Companies (million AMD)..........................35

Table 7. Largest Outstanding Commercial Debts of State-Owned Companies ......................................... 35

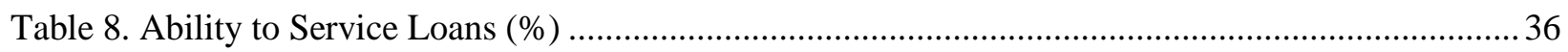

Table 9. ENA's Payments and Debt to State-Owned Power Companies (\%) ........................................... 36

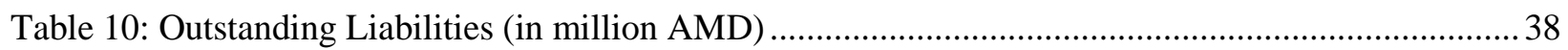

Table 11. O\&M Costs, Depreciation Expenses, and Return on Assets (million AMD) .............................39

Table 12. Pipeline of Main Power Generation Projects to Meet Domestic Demand by 2019 ...................41

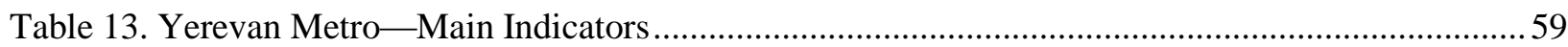

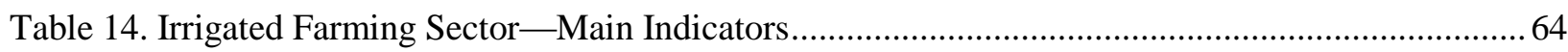

Table 15. Improvements in the WSS Sector since 2000-Yerevan DJUR .........................................67

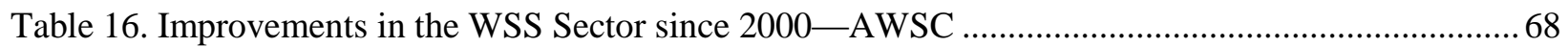

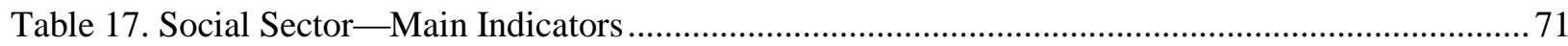

Table 18. Advantages and Disadvantages of Mitigation Mechanisms …................................................ 74

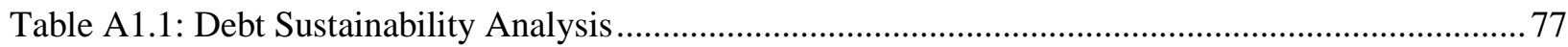

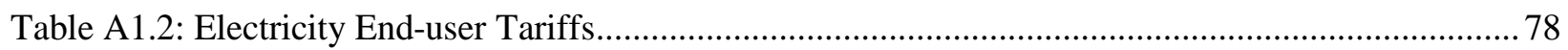

Table A2.1: Inflation Rate Forecast, as per the IMF World Economic Outlook, April 2015................... 78

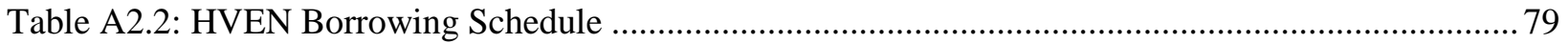

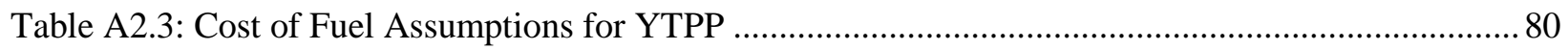




\section{Acknowledgements}

This report was prepared by the World Bank team led by Gohar Gyulumyan (Senior Economist and TTL, GMF09) and Rashmi Shankar (Lead Economist and Program Leader, ECCU3, TTL), and consisting of a core team including Mariam Dolidze (Senior Economist, GMF09), Genevieve F. Boyreau (Senior Economist, SACBT07031), Nistha Sinha (Senior Economist, GPOV03), Tigran Kostanyan (former Economist, World Bank), Irina Capita (ET Consultant, GMF03), Elena Bondarenko (Economist, GMF09), Hirut Wolde (Consultant, GGOGS), Arthur Kochnakyan (Senior Energy Economist, GEE03), Borko Hadjinski (former Senior Economist, World Bank) and Emil Zalinyan (Consultant, GEE03). Naoko Kojo (Senior Economist, GMF09) and Steve Goss (Consultant) also contributed to the report.

The team is grateful to Mercy Miyang Tembon (Regional Director, ECCU3), Miria Pigato (Practice Manager, GMF09) and Laura Bailey (Country Manager, ECCAR) for guidance, review and useful comments. The team appreciates Rob Taliercio (Practice Manager GG014) and Pedro L. Rodriguez (Program Leader, LCC6C) for peer review and useful comments. Administrative support was provided by Sarah Babirye (Program Assistant, GMF09) and Gayane Davtyan (Program Assistant, ECCAR). 


\section{Executive Summary}

\section{A. Overview and Analytic Framework}

1. The objective of this report, which is the third in a series of programmatic public expenditure reviews (PPER), is to identify potential measures to strengthen public finances in line with the Government's strategy to reduce fiscal risks and support budgetary consolidation. The PPER series assesses public expenditures and their alignment with development goals.

2. For this phase of the PPER, three areas were identified with the Government as absent from previous reports yet of particular relevance given growing spending pressures. The first is efficiency of government spending on social sectors and public investment, where efficiency is defined in terms of outcomes achieved. The second area of relevance encompasses quasi-fiscal risks and contingent liabilities of the energy sector. The third area pertains to selected subsidies, which are budgeted to rise exponentially in 2016. This report is anchored in the Country Partnership Strategy (CPS) pillars of improving governance, efficiency of public administration, and service delivery.

3. This report is divided into three chapters, each covering the very distinct fields of fiscal management identified above:

- Chapter 1: on Macroeconomic and Fiscal Challenges;

- Chapter 2: on Quasi-Fiscal Pressures of the Energy Sector; and

- Chapter 3: Assessment of Explicit Budget Subsidies.

4. The report employs highly discrete conceptual and analytic frameworks for each of the analyzed areas in order to draw conclusions and provide recommendations. The chapter on macroeconomic and fiscal challenges examines macro-fiscal trends and provides a comparator country benchmarking analysis of public expenditures and outcomes. The cross-country benchmarking is based on Data Envelopment Analysis (DEA), which measures the relative efficiency of public spending looking at multiple inputs and outputs. The chapter on quasi-fiscal pressures presents a detailed assessment of quasi-fiscal risks and estimates of contingent liabilities stemming from the energy sector's recent performance. The chapter on budget subsidies relies on the methodological framework offered by the IMF Government Financial Statistics (GFS-2001) and compares consistency of Armenia's practice with international experience. 


\section{B. Context}

5. Similar to other countries in the region, Armenia faces the challenge of maintaining a sustainable fiscal framework against a backdrop of slowing economic growth and a limited scope for further spending cuts. Following the 2008-2009 countercyclical fiscal stimulus, the fiscal deficit jumped to nearly 8 percent of GDP, which contributed to a significant scale up in public debt. A period of fiscal consolidation ensued, with public investment cuts taking the brunt of the adjustment. During the 2009-2014 period, public investment fell from 6.7 to 2.3 percent of GDP and the fiscal deficit fell to 2.1 percent of GDP. However, regional shocks, including the economic contraction in Russia and the slow-down in Europe and China, have largely derailed Armenia's post-2008 growth recovery, reducing government revenues to 22 percent of GDP and pushing up expenditures, especially in the social sectors. As a result, the fiscal deficit in 2015 grew to 4.8 percent and is projected to remain around 4.1 percent in 2016. Total public debt approached the legal maximum of 49 percent defined by fiscal rules framework, leading to a legal amendment to permit more borrowing. The next round of fiscal consolidation will have to be based on domestic revenue mobilization and greater public spending efficiency. Public investment, which took the burden of fiscal consolidation in 2010-2014, cannot be cut any further given its role in attracting private investment and directly stimulating growth. The estimated increase in GDP growth due to a 1 percent increase in public investment is more than 0.3 percent; and international evidence suggests that this impact can be strengthened through complementary structural reforms focused on improving productivity.

6. Armenia's poverty and inequality remain higher today than in 2008, but the constrained fiscal space restricts policy options to address social vulnerabilities. Although some progress in poverty reduction was achieved during the post-crisis recovery, 30 percent of the population was below the national poverty line in 2014, compared to a post-independence low of 26.4 percent in 2007. Inequality also increased in response to the economic crisis and the sluggish recovery thereafter, and the Gini coefficient rose from 0.24 in 2008 to 0.28 in 2014 (based on national consumption expenditures). Armenia's performance in boosting shared prosperity is among the weakest in the region. In the past, remittances have been an important driver of poverty reduction, but they declined sharply during the recession in Russia. The fiscal space is currently too limited to make large spending increases a viable option.

7. Preserving debt sustainability is a priority going forward. Public debt increased from 16 percent of GDP in 2008 to almost 49 percent in 2015. While Armenia's public debt remains sustainable (See Annex 1), there are high downside risks stemming mainly from the external environment and continued sluggish growth. External debt is a significant source of vulnerability, and the repayment obligation of the 2013 and 2015 Eurobond in 2020 and 2025 sharply increases the government's financing needs. Alternative scenarios and stress tests indicate that an adverse growth shock would have the largest impact on debt dynamics and government financing needs.

8. In the current macro-fiscal context, it is clear that the focus of fiscal policy in the medium term will need to be on public spending efficiency. This report will provide useful 
analysis in this regard by building on the previous PPERs (2012 and 2014). Recent policy changes have included: (i) savings from administrative efficiency of the government by introducing integrated social service delivery and introducing e-services in most of the key government agencies, including e-filing of tax returns and e-declarations for customs clearances; (ii) the creation of the fiscal risks management unit in the Ministry of Finance; (iii) modernization of the tax legislation, namely drafting a unified tax code, which is projected to increase government revenues by 2 percent of 2015 GDP. This report will inform the larger Government strategy by focusing on two main issues: (i) reducing fiscal risks through strengthened financial management in the state-owned energy companies; and (ii) reviewing expenditures on subsidies to uncover potential cost savings. A complementary technical assistance on tax policy is supporting the preparation of the tax code, which is therefore not assessed here.

\section{Recap of Preceding PPERs}

9. It is useful to summarize the key conclusions of the previous work in the programmatic PER series before discussing the findings of this report. The 2012 PER contributed to the government's post-2009 fiscal consolidation agenda by reviewing both the revenue and expenditure sides of the state budget (World Bank, 2012). ${ }^{1}$

- While suggesting a few clear opportunities to expenditure saving and efficiency increases, the report concluded that there are no "low-hanging fruits" or spending categories that could be cut or reallocated.

- Moreover, several categories of public spending that are growth-supporting by nature require significant increases to meet the economy's needs for infrastructure and human capital development (education, education and public sector remuneration).

- Given the limited room for spending cuts or inter-sectoral re-allocations, the report concluded that the medium-term fiscal consolidation agenda should be facilitated by enhancing the revenue side of the fiscal system.

- It highlighted specific directions and policy measures that could lead to stronger domestic revenue mobilization efforts. In particular the report assessed Armenia's tax collection potential under the current fiscal framework and suggested specific administrative techniques to improve tax collection.

10. The 2014 PER focused on options for the government to expand the fiscal envelope (World Bank, 2014). It looked at tax exemptions and quantified tax expenditures to estimate the additional fiscal space, examined the extent of redistributional aspects of public programs, and reviewed the public sector pay system.

I. More specifically, recommendations on tax expenditures referred to:

${ }^{1}$ World Bank, Fiscal Consolidation and Economic Recovery, 2013 
- Removing tax exemptions on corporate and income taxes on commercial agricultural activities, the tax on interest on government bonds, the tax on dividends, and the VAT on financial services;

- Creating a unit (within the tax policy department) in charge of tax expenditures;

- Developing government capacity to estimate the revenue loss of tax expenditures, including the use of an appropriate database;

- Analyzing the economic and social impact of tax expenditures with a focus on relevance, effectiveness and efficiency;

- Setting a timetable and target date to begin presenting tax expenditures with the annual state budget;

- Ensuring there are no open-ended tax reliefs and each relief is time-bound;

- Developing modalities for engaging interested parties and the public at large to get a buy-in for the removal of tax privileges.

11. Supplementing the analysis of the 2012 PER, which looked at sectoral allocations of public spending, the 2014 PER also presented a detailed fiscal incidence analysis to examine the efficiency of the redistributional aspects of the government's fiscal policy. It concluded that Armenia's fiscal policy is equitable, as most of the expenditures are progressive, but the small scope of public programs limit their potential effects on the population's welfare.

II. The main recommendations and findings of the 2014 report pertaining to fiscal incidence included:

- Reviewing the redistributional aspects of public spending and assessing whether there is a need to expand them;

- Searching for the best administrative mechanisms to increase redistribution to the poor - is there an alternative to the family benefit program given its current targeting?

- From an equity perspective, the tax reform should consider either increasing rates for direct taxes or drawing more workers into the formal economy.

12. Most of the above recommendations on tax policy have been taken into account by the government during successive periods of annual budget preparation or during the unified tax code consultations in 2015-2016. However, recommendations on the redistributional aspects of the fiscal policy based on the fiscal incidence analysis have had limited traction thus far. The current report may help to reinforce the need to improve the distributional impact of public spending by increasing the efficiency of public spending.

\section{Key Findings of the Report}

13. There is room to strengthen expenditure efficiency in Armenia, especially in growth-enhancing public investment and social spending that includes health and education. Overall, Armenia's state budget (including allocations for social sectors) is relatively low compared to lower middle-income countries (LMICs), Commonwealth of Independent States (CIS) countries, and the European Union (EU). However, social outcomes are better than the 
LMIC average, on par with the CIS countries, and lagging behind the EU. Nevertheless, the same social outcomes could be achieved with lower allocations from the budget. In particular, specific sub-sectors within health and education require special attention. Public investment as a percent of GDP has declined throughout the post-crisis period and remains small, posing a clear challenge to the country's growth prospects. In addition to further improvement of expenditure efficiency, targeting of public spending and access by the socially vulnerable need to be improved to prevent catastrophic spending. As the 2012 PER revealed, "catastrophic" health spending may drive an extra 6 percent of Armenian households into poverty.

14. Overall, spending is highly pro-cyclical, suggesting that fiscal management needs to be strengthened. While assessing the proposed tax code is beyond the scope of this report, the plateauing of tax revenues in recent years coupled with growing fiscal constraints suggests that fiscal reform is, indeed, a priority and every effort should be made to ensure revenue enhancement. In terms of expenditures, the decline in capital spending appears to have been largely driven by policy but also affected by under-execution. Actual capital spending has averaged at only 65 percent of budgeted resources. In some cases, large partially donor-financed projects have not been initiated. Weaknesses in project planning and implementation capacity are of concern given the important role played by public investment in potentially ensuring access to public services, facilitating investment in human capital, leveraging private investment, and supporting job creation and growth.

15. The power sector's financial performance has deteriorated in recent years, raising concerns about quasi-fiscal obligations. Increasing power supply reliability has been identified as a key priority in order to boost growth. The first-generation power sector reforms in Armenia during 1998-2005 produced strong results and led to remarkable improvements in the energy sector financial sustainability and privatization. However, starting in 2010, the sector's performance has significantly weakened and new pressures have led to an increase in the potential liabilities for the state. The power sector's financial deficit was 1 percent of GDP at end-2014. In addition, much of the sector's outstanding debt is short-term and commercial, with annualized interest rates of 10-11.75 percent. Hence, in the currently fragile macro-fiscal environment, containing the growth of contingent liabilities and restoring fiscal sustainability to the sector is a high priority.

16. In addition to implicit liabilities induced by the energy sector, fiscal policy may face serious limitations in the medium term because of the accumulated stock of tax credits. Throughout 2010-2014, the actual tax collection was supported by tax credits paid by active taxpayers. ${ }^{2}$ By the end of 2014, the stock of tax credits was more than two times larger than the stock of overdue tax arrears, which indicated net implicit subsidization of the state budget by the private sector of over 3 percent of GDP. This suggests that the net liabilities of the fiscal sector are significantly larger than the quasi-fiscal obligations generated by the power sector (Table 1). The current state of implicit subsidization is a reverse picture of 2002-2003, when the state budget was

\footnotetext{
${ }^{2}$ Tax credits constitute the state budget's commitments against the private sector in a form of advance receipt of tax payments, due VAT refunds etc.
} 
the source of hidden subsidies to utility companies and to the population because of the interrelated chain of arrears and non-payments (Freinkman et al., 2003).

Table 1. Quasi-Fiscal and Fiscal Liabilities (stock, as of end-2014)

\begin{tabular}{|l|c|c|}
\hline & $\begin{array}{l}\text { Implicit and explicit liabilities } \\
\text { (billion AMD) }\end{array}$ & $\begin{array}{l}\text { Implicit and explicit liabilities } \\
\text { (percent of GDP) }\end{array}$ \\
\hline $\begin{array}{l}\text { Quasi-fiscal obligations of the } \\
\text { power sector (1) }\end{array}$ & 47.4 & 1 \\
\hline Tax arrears & -103.4 & -2.1 \\
\hline Tax credits & 258.7 & 5.3 \\
\hline Net Tax arears (2) & 155.3 & 3.2 \\
\hline $\begin{array}{l}\text { Net quasi-fiscal and fiscal } \\
\text { liabilities (1+2) }\end{array}$ & 202.7 & 4.2 \\
\hline
\end{tabular}

Source: MoF, NSS and WB staff calculations based on the financial statements of the state-owned power companies and the publicly available data from the Public Services Regulatory Commission

17. Besides posing potential liabilities for the state budget, the power sector demands large repair and rehabilitation investments in order to ensure that supply keeps up with the growing demand. Non-core business-related transactions-including borrowing for on-lending to the Nairit and Vanadzor chemical plants-led to a need for state-owned energy companies (SECs) to reduce essential operations and maintenance (O\&M) expenditures and take high-interest commercial loans from banks. In mid-2015, the outstanding debt of these two plants to the SECs was at AMD 28 billion (0.6 percent of GDP). Some large expenses unrelated to the power sector and amounting to more than AMD 3.7 billion were also incurred. Consequently, even when including other receivables from the chemical companies, there is a high probability that the SECs would need to write off AMD 33 billion in losses. Additionally, the distribution company ENA has been incurring losses due to exogenous factors, causing it to accumulate liabilities that are receivables to the SECs. By end-2014, ENA's total losses had reached AMD 40 billion. Meanwhile, tariff increases have been insufficient to ensure cost coverage, given inadequate provision for O\&M and depreciation. Finally, nearly $\$ 1$ billion in new power transmission investment would be needed by 2019, including for rehabilitation of substations and transmission lines, strengthening of interconnections with neighboring countries, and expansion of capacity to meet growing demand. Of this, at least \$200 million would come from public sector borrowing, which would be either directly taken by the state or state-guaranteed.

32014 GDP amounted to AMD4,843billion 
18. At 0.5 percent of GDP, explicit subsidies do not represent a large share of Armenia's expenditures; however, a significant number of outlays require review, particularly given the current fiscal constraints. ${ }^{4}$ An assessment of the scope of rationalization of subsidies is appropriate given the need for fiscal consolidation without further compromising public investment programs. Subsidies in Armenia range from the traditional, i.e. based on the IMF Government Financial Statistics definition, to the particular, which are not consistent with international practice and should, in fact, be classified as block grants. While Armenia's subsidy reporting is sound, impact assessment through monitoring and evaluation is typically not adequate. The State Non-Commercial Organizations that are large recipients of subsidies are not budgetary institutions and usually remain outside of the external oversight/audit.

19. Only one-third of expenditures budgeted as subsidies can justifiably be classified as such; furthermore, there is opportunity to strengthen cost recovery in utility sectors and reallocate resources for increasing the share of targeted benefits. Since there is no monitoring and evaluation mechanism in place to verify that the intended impact of the subsidy is being realized, assessing the effectiveness of subsidies is difficult. However, there is scope for improving operational efficiency, tariff reform, and cost recovery in some sectors. In railways, for example, where there is a concession in place and a subsidy agreement, there has been significant investment without substantial performance improvements in either container or passenger traffic. As a result, operational losses have grown in the absence of tariff increases, ultimately outstripping the subsidy. In the agricultural sector, AMD 2 billion in subsidies are disbursed each year, mainly for irrigation and credit for farmers. However, irrigation water subsidies benefit large farmers and discourage investment in water saving devices. Moreover, as energy costs increase, expenditures on maintenance are being squeezed. Again, there is a strong case for tariff reform to support cost recovery. Where financial support is warranted, it is best to replace subsidies with: (a) beneficiary-based targeting schemes where equity is the objective, as they could be more equitable based on pre-identified indicators; or (b) schemes based on performance where efficiency is the objective, as they could be more efficient in influencing incentives.

20. Table 2 summarizes the broad recommendations offered by this PER. More granular recommendations are detailed in the three chapters that follow.

Table 2. Key Findings and Policy Recommendations for Consideration

\begin{tabular}{lll}
\hline Policy Area & Key Findings & \multicolumn{1}{c}{$\begin{array}{c}\text { Policy } \\
\text { Recommendations }\end{array}$} \\
\hline & $\begin{array}{l}\text { Armenia's fiscal policy (government } \\
\text { spending) has been pro-cyclical }\end{array}$ & $\begin{array}{l}\text { 1. A countercyclical spending } \\
\text { policy is desirable because it can } \\
\text { transfer resources to less favored }\end{array}$ \\
\hline
\end{tabular}

\footnotetext{
${ }^{4}$ The approved 2016 State Budget suggests a substantial increase in budget subsidies up to 2.3 percent of the projected GDP for 2016
} 


\begin{tabular}{|c|c|c|}
\hline Policy Area & Key Findings & $\begin{array}{l}\text { Policy } \\
\text { Recommendations }\end{array}$ \\
\hline \multirow[t]{4}{*}{$\begin{array}{l}\text { Macroeconomi } \\
\text { c and Fiscal } \\
\text { Challenges }\end{array}$} & & $\begin{array}{l}\text { individuals, and it can serve to } \\
\text { stimulate real economic activity in } \\
\text { the event of shortfalls in aggregate } \\
\text { demand. A countercyclical fiscal } \\
\text { policy is an important macro risk } \\
\text { management tool. }\end{array}$ \\
\hline & $\begin{array}{l}\text { Public debt scaled up but remains } \\
\text { sustainable though risks are elevated. } \\
\text { Growth response to debt pile-up has been } \\
\text { weak raising concerns over the } \\
\text { efficiency of public resource allocation }\end{array}$ & $\begin{array}{l}\text { 1. To stabilize and reduce the public } \\
\text { debt level, fiscal consolidation should } \\
\text { start as early as } 2016 \text { and focus on } \\
\text { revenue increases rather than on } \\
\text { spending cuts. }\end{array}$ \\
\hline & for consumption expenditures. & $\begin{array}{l}\text { 2. In light of the significant } \\
\text { uncertainty surrounding macro } \\
\text { projections and the forthcoming } \\
\text { sizeable external (Eurobonds) debt } \\
\text { payments, a prudent debt } \\
\text { management policy is needed to } \\
\text { ensure that the financing needs of the } \\
\text { government are met at minimum } \\
\text { cost. }\end{array}$ \\
\hline & $\begin{array}{l}\text { Despite the low level of public spending } \\
\text { on health, education and social } \\
\text { protection, Armenia's social attainments } \\
\text { are not lagging behind its peers. }\end{array}$ & $\begin{array}{l}\text { 1. The current relatively better } \\
\text { outcomes could be explained by } \\
\text { different factors, which however } \\
\text { will not guarantee similar } \\
\text { outcomes in the long term. To } \\
\text { sustain these outcomes the } \\
\text { government may consider } \\
\text { increasing budget allocations } \\
\text { along with improved efficiency } \\
\text { and productivity of sectoral } \\
\text { spending. }\end{array}$ \\
\hline
\end{tabular}




\begin{tabular}{lll}
\hline Policy Area & Key Findings & \multicolumn{1}{c}{$\begin{array}{c}\text { Policy } \\
\text { Recommendations }\end{array}$} \\
\hline $\begin{array}{l}\text { Public } \\
\text { investment and } \\
\text { growth }\end{array}$ & $\begin{array}{l}\text { A public expenditure mix between } \\
\text { recurrent and capital spending provides } \\
\text { for inadequate allocation for the latter } \\
\text { and may undermine the country's future } \\
\text { growth prospects. }\end{array}$ & $\begin{array}{l}\text { 1. Improve the share of public } \\
\text { investment and strengthen the } \\
\text { alignment of public investment } \\
\text { with the government's } \\
\text { development objectives. }\end{array}$ \\
& $\begin{array}{l}\text { The quality of infrastructure will } \\
\text { deteriorate if the observed trend of } \\
\text { underfunding capital expenditures } \\
\text { continues in the longer term. }\end{array}$ & $\begin{array}{l}\text { 2. Strengthen the project cycle with } \\
\text { a focus on identification under } \\
\text { objective criteria, sound planning, } \\
\text { assessment of costs and } \\
\text { implementation needs, and } \\
\text { accountability for reducing the gap } \\
\text { between planned and executed } \\
\text { expenditures. }\end{array}$ \\
&
\end{tabular}

Quasi-fiscal risks in the power sector
The power sector's financial performance has been deteriorating since 2010 as a result of the government's several actions and policies, including: (a) non-core business related borrowing, lending, and expenses; (b) an inadequate mechanism for compensating exogenously caused losses of ENA; and (c) below cost-recovery tariffs for state-owned power companies.
1. Prohibit expenses, borrowing, and lending that are not related to the core business of state-owned power companies.

2. Consider developing and implementing a liquidation plan for the Nairit chemical plant and start a legal process to collect the Vanadzor chemical plant debts.

3. Allow for recovery of ENA's AMD 30 billion in losses, which accumulated for external reasons.

4. Adjust the regulatory/tariff methodology to avoid repetition of ENA's loss build-up due to a mismatch between the forecast and the actual power generation mix.

5. Introduce adjustments in O\&M costs and abandon the practice of 


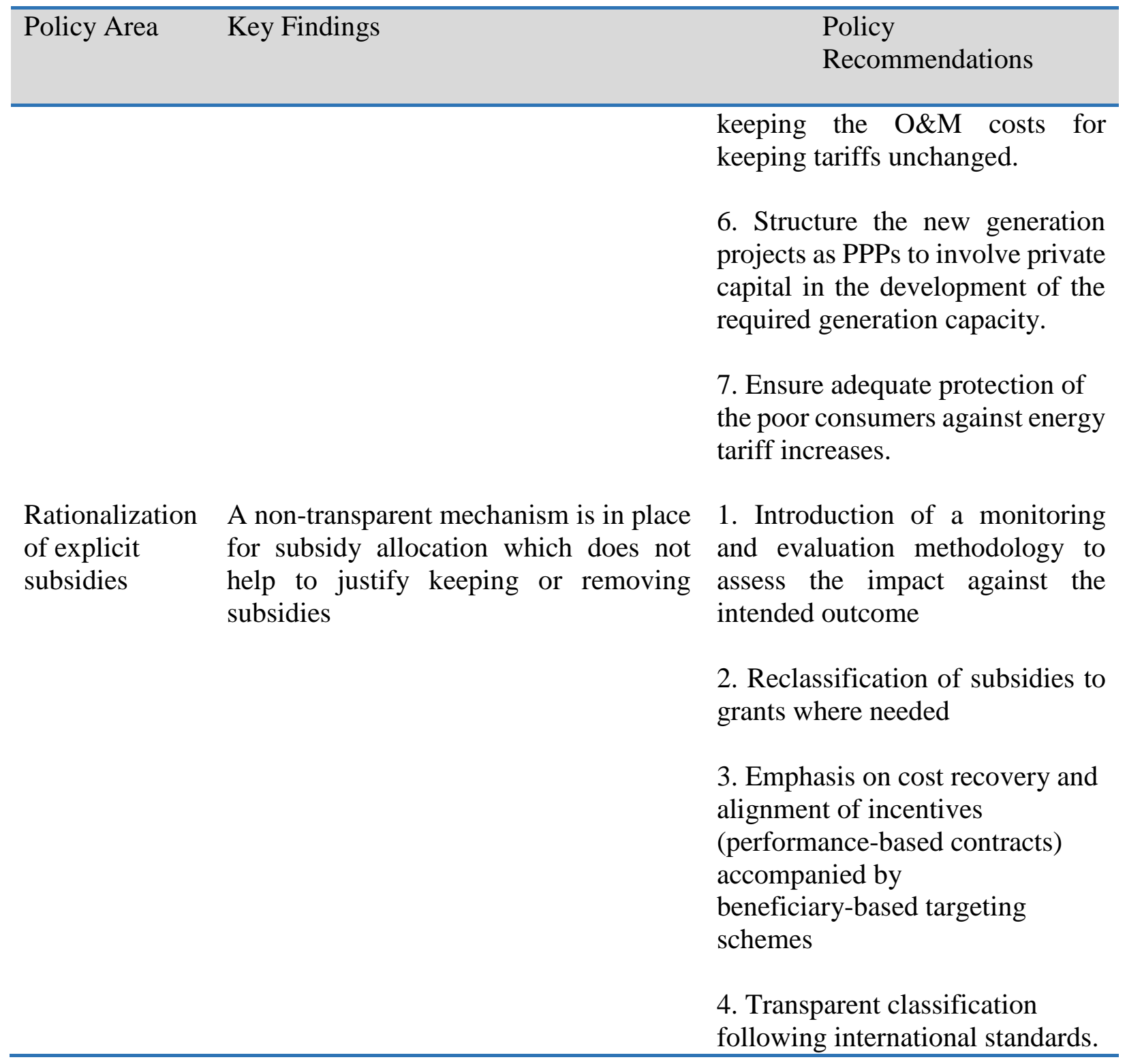




\section{Chapter 1. Macroeconomic and Fiscal Challenges}

\section{A. Overview}

1.1. Armenia's fiscal space is constrained and the government faces difficult trade-offs in the current low-growth environment. The average annual growth remained only slightly above 4 percent in the post-crisis period of 2010-2015 and real GDP recovered to 2008 levels only in 2013. The government implemented a fiscal stimulus package during the 2010-2015 period; however, growing recurrent and social spending has constrained the public investment envelope and a difficult external environment has deterred private investment. As a result, the Armenian economy remains vulnerable to external shocks, which points to the need to build up fiscal buffers even as growth slows down following the contraction in Russia and its spillover effects on Eurasia.

1.2. Between 2009 and 2014, the main driver of the consolidation effort was a broad-based expenditure downsizing. The spending cuts disproportionately affected almost all expenditure items, with the public investment programs bearing the brunt of the adjustment. Between 2011 and 2014, fiscal consolidation evolved somewhat faster than expected, mainly because of the under-execution of capital expenditures, which dropped from 7 percent of GDP in 2009 to as low as 2.3 percent in 2013-2014. The overall execution of the capital budget modestly improved in 2015, reaching 2.9 percent of GDP, which nonetheless remains low and needs to increase, as does the predictability of its execution. Meanwhile, current spending was scaled up during the 2008-2015 period. The largest fiscal increases were absorbed by social allowances, subsidies, pensions, and interest payments. At the same time, substantial progress was achieved in terms of revenue collection, which saw an increase of about 2.1 percentage points of GDP between 2009 and 2013 but stagnated at 22 percent of GDP in 2014 and deteriorated by 0.5 percentage points of GDP in 2015. Despite the significant negative impact of trade taxes (VAT on import and customs duties), the overall tax collection did not deteriorate significantly because of positive contributions by domestic taxes.

1.3. The public debt-to-GDP ratio has tripled since 2008, going mainly toward the financing of public consumption spending. As government borrowing increased to finance the fiscal stimulus during the 2008-2009 crisis, external public debt increased by 22.1 percent of GDP to 35.7 percent in 2009 and further to 41.0 percent in 2015. A large share of the public borrowing was generated by an issuance of Eurobonds in 2013 (about 6.4 percent of GDP) and in 2015 (about 4.7 percent of GDP) which were partially used first to refinance a sizable emergency loan from Russia that was disbursed during the 2009 crisis and then to refinance it in 2015. Between 2013 and 2015, the stock of total public debt, including both domestic and external, increased by about 20 percent, reaching 48.8 percent of GDP by the end of 2015. However, despite a considerably scaled-up debt stock, growth has been weak, raising concerns over the efficiency of public resources allocated by the Government of Armenia (GoA) for consumption expenditures. To stabilize and reduce the public debt level, fiscal consolidation should start as early as 2016 and focus on revenue increases rather than on spending cuts (Annex 1).

1.4. While public investment is relatively low, the quality of Armenia's infrastructure is better than that of other ECA countries that tend to spend more. Armenia's low levels of 
capital spending do not necessarily imply a poor quality of infrastructure, as would commonly be the case in transition countries. In fact, with capital public spending at less than 3 percent of GDP, Armenia's overall quality of infrastructure such as roads places the country somewhere in the middle among ECA transition countries. That said, a note of caution is warranted for two main reasons. First, investment projects typically involve longer planning horizons spanning many years. Second, the effect of public spending on the quality of infrastructure could be lagged dependent. Thus, the quality of infrastructure may deteriorate if underfunding continues in the longer term.

1.5. Countercyclical fiscal policy is an important macro risk management practice; however, Armenia's government expenditures show high pro-cyclicality. With a 31 percent correlation with the cyclical component of GDP from 2005 to 2015, Armenia's government spending is clearly pro-cyclical. In contrast, industrial countries with countercyclical fiscal spending have a negative correlation - for example, that of U.S. public spending is -94 percent of GDP. Countercyclical fiscal policy is particularly important for Armenia given that the alternative - monetary policy — is quite weak in a highly dollarized market.

1.6. This chapter is divided into two additional sections. Section B presents and analyzes efficiency of social and capital spending through benchmarking. Section C discusses fiscal developments and expenditure trends.

1.7. The chapter reveals that by some measures efficiency of social spending in Armenia is higher than its peers at the same income level:

- Social spending. Despite spending significantly less (relative to GDP) than other countries, Armenia's outcome indicators are not bad.

- Education. Even though Armenia's education spending is lower than comparable countries, education outcomes are good, suggesting the government's education spending is effective.

- Health. Although limited resources are allocated both in terms of percent of GDP and per capita, Armenia's health outcomes are not too poor owing to the restructuring of the health system.

- Social protection. Armenia spends more on social protection than LMICs but less than CIS and EU countries. Armenia's social spending is effective in reducing poverty.

- Capital expenditure. Similarly, the efficiency of capital expenditure is not significantly low, despite the falling trend of public investment spending observed in the last few years.

1.8. The above observations can be explained by different factors, including the legacy of the good social outcomes from the soviet era, early implementation of the first generation of institutional and structural reforms - which helped to introduce more efficient per-capita financing, contracting, and management/governance systems, such as the creation of the State Health Agency for allocation/purchase of services - and significant diaspora assistance received through non-budgetary channels. 


\section{B. Benchmarking the Government's Performance Social Spending}

1.9. A profile analysis of Armenia's expenditure performance vis-à-vis three country groups reveals comparative efficiency indicators. A benchmarking exercise comparing Armenia's general government expenditure performance with three groups including Lower Middle Income Countries (LMICs), South Caucasus and CIS Countries (CIS), and EU countries for 2012 revealed that even though Armenia's general government spending is the lowest compared to the average spending of each group, its performance as measured by selected MDG outcome indicators is not the worst. Also, in terms of poverty indicators as measured by the "human development index" (HDI), Armenia far outperforms LMICs, is slightly better than CIS countries and lags behind EU countries. In terms of equality as measured by the "Gini index" Armenia outperforms LMICs, and is on par with CIS and EU countries.

1.10. Reflecting the limited expenditure envelope, Armenia allocates less public spending on the social sector. In the health sector, even including private sector health spending, Armenia spends 3.3 percent less than CIS countries and 4.3 percent less than EU countries. Similarly, in the education sector, Armenia spends 1.1 percent less than the LMICs average and around 3 percent less than CIS and EU countries. In the area of social protection, while Armenia spends 2.4 percent more than LMICs, it lags behind both CIS and EU countries by about 4 percent and 10 percent, respectively. Armenia spent 6.8 percent of GDP in the social services sector in 2012, which is far more than the 3 percent spent by LMICs and far less than the 11 percent and 17 percent spent by CIS and EU countries, respectively (Figure 1).

Figure 1. Government Spending in the Social Sectors (\% GDP)

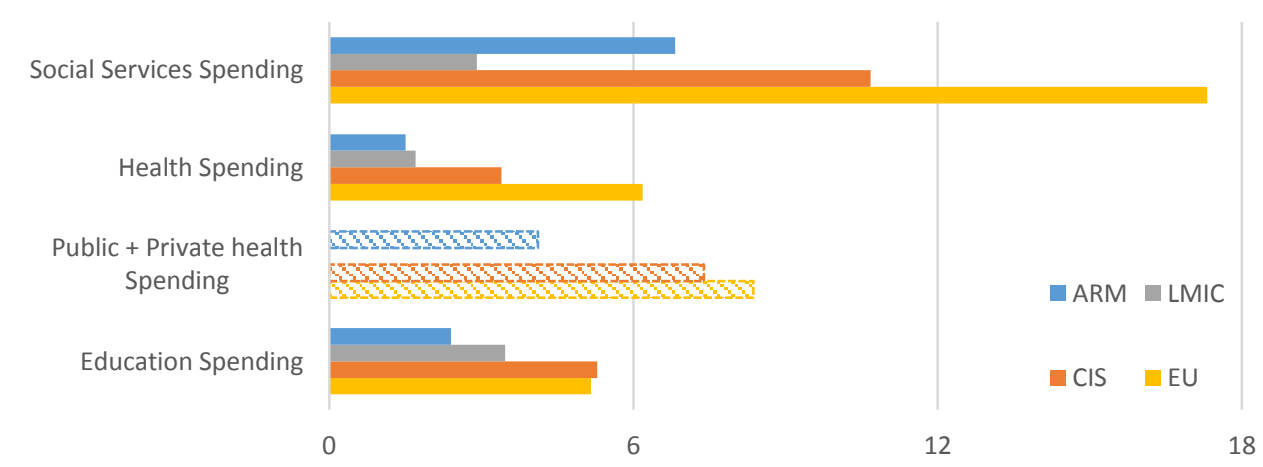

Source: IMF GFSY and WDI, on private health spending.

Note: Data coverage and basis are as follows: General govenment cash basis: BGR, BLR, CZE,EGY,

1.11. Notwithstanding the low level of spending, Armenia's performance as measured by selected outcome indicators is not among the worst (Figure 2). In terms of the mortality rate as measured by "infant mortality per 1,000 live births," Armenia lags behind CIS countries and significantly lags behind EU countries. In terms of the indicator "life expectancy at birth, female, years," Armenia outperforms CIS countries but lags behind EU countries. Regarding "school 
enrollment (secondary \% net)," Armenia's performance is better than that of LMICs, is on par with CIS countries, and lags behind EU countries.

Figure 2. Selected Performance Indicators: Deviation from Group Average

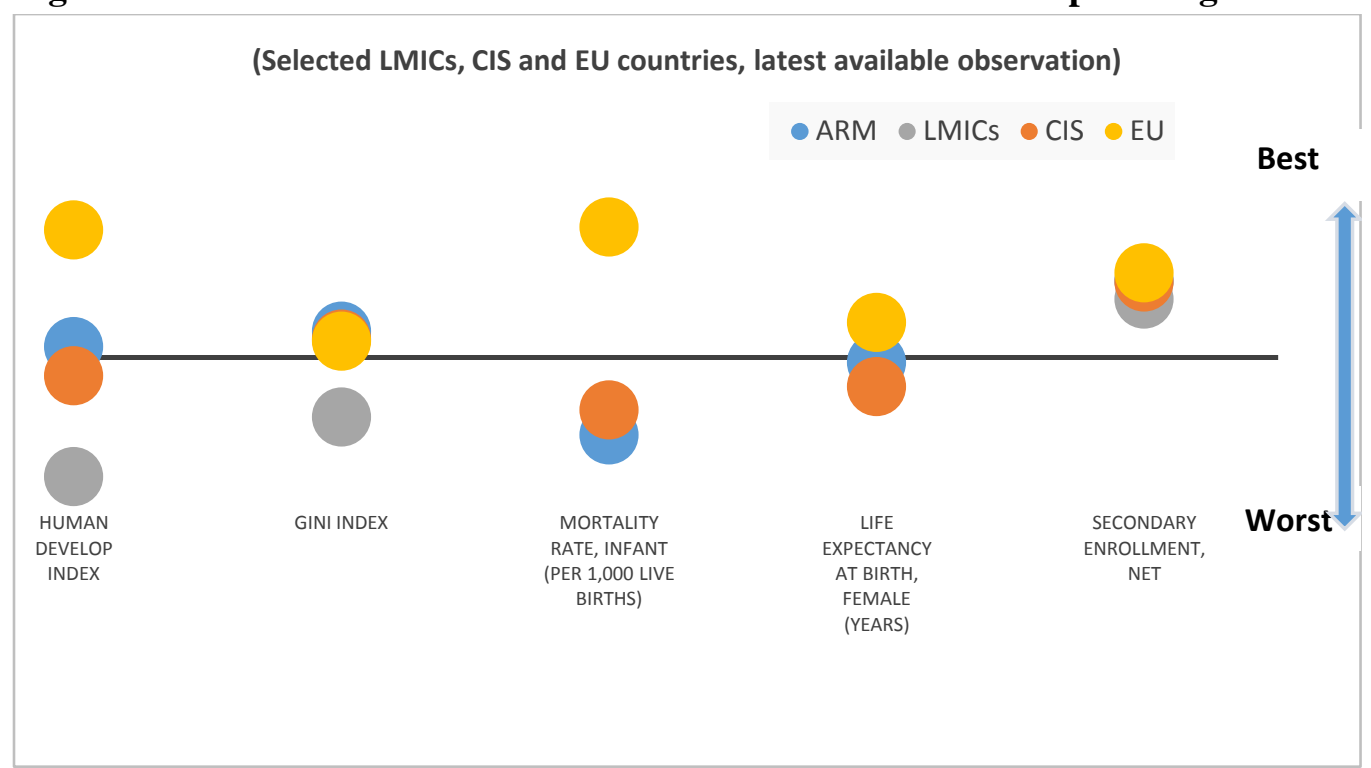

Source: WDI and United Nations.

Note: Outcome values scaled for presentation; infant mortality and life expectancy rates data for LMICs not available.

1.12. One possible explanation for Armenia's relatively better performance could be that factors other than government spending have influenced outcomes. The 2010 United Nations Development Assistance Framework, as an example, attributes Armenia's improvement in the HDI to "the increase in income per capita as opposed to improvement in social development." Similar results were achieved in health, education, and social protection, with some variation across these social sectors. Even though Armenia's per capita sector spending is the lowest compared to the average per capita sector spending in each group, sectoral performance as measured by selected outcome indicators, while lagging behind EU countries, is not as low as would be expected compared to CIS countries and LMICs (Table 3). The next two subsections delve into health and education spending in more detail. 
Table 3. Selected Outcome Indicators for Social Sectors, Latest Available Observation

\begin{tabular}{|c|c|c|c|c|}
\hline Outcome Indicators & ARM & LMIC & CIS & $\mathrm{EU}$ \\
\hline \multicolumn{5}{|l|}{ Health } \\
\hline Incidence of tuberculosis (per 100,000 people) & & & & \\
\hline \multicolumn{5}{|l|}{ Physicians (per 1,000 people) } \\
\hline \multicolumn{5}{|l|}{ HALE (health adjusted life expectancy, years) } \\
\hline \multicolumn{5}{|l|}{ Education } \\
\hline \multicolumn{5}{|l|}{ Adult literacy rate (\% of people ages 15 and above) } \\
\hline \multicolumn{5}{|l|}{ Secondary gross enrollment (ratio total) } \\
\hline \multicolumn{5}{|l|}{ Lower secondary completion rate } \\
\hline \multicolumn{5}{|l|}{ Tertiary gross enrollment (ratio total) } \\
\hline \multicolumn{5}{|l|}{ Social Protection } \\
\hline Human Development Index & 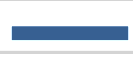 & 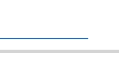 & س & \\
\hline \multirow[t]{2}{*}{ Gini Index } & & & & \\
\hline & \multicolumn{4}{|c|}{ The longer the bar the better } \\
\hline
\end{tabular}

Source: WDI and UNDP

\section{Health}

1.13. In the health sector, the relatively low per capita spending is linked to poor outcomes; however, they are not much worse than the CIS group average, as would be expected. Even including private sector health spending, Armenia spends 3.3 percent less than CIS countries and 4.3 percent less than EU countries. Looking at the four available health outcome indicators - infant mortality rates, incidence of tuberculosis (per 100,000 people), physicians per 100,000 people, and "HALE" (health adjusted life expectancy at birth) - Armenia's performance significantly lags behind EU countries and slightly lags behind CIS countries. In terms of the only outcome indicator where data is available for LMICs, Armenia significantly outperforms LMIC.

1.14. The efficiency gains could partly explain why Armenia's outcomes in the health sector are not as poor as would be expected given its level of spending. An evaluation of the government's spending efficiency in the health sector using the DEA technique shows that Armenia's health spending is relatively efficient compared to other countries in the sample. With an efficiency score of 1.0, Armenia's health spending efficiency reaches the efficient frontier (most efficient) along with countries like Bulgaria, the Czech Republic, Finland, Greece, Italy, Luxemburg, and Romania (Figure 3). Other factors outside the size and efficiency of health spending that could explain this, according to various studies, include the existing capacity of medical personnel and/or public health officials along with existing technology and the quality of drugs and equipment.

1.15. Armenia has made important strides since the $1990 \mathrm{~s}$ in restructuring its health system. Major institutional and structural reforms have been undertaken with the overall objective of improving efficiency, access, and the quality of health care service provision. The reforms have 
included: (a) strengthening Primary Health Care (PHC) provision; (b) downsizing excess hospital capacity; (c) changing provider payment mechanisms and introducing a purchaser-provider split; and (d) targeting the poor in providing free-of-charge health care services. At the primary care level, Armenia has established the family medicine model and retrained doctors. At the hospital level, it has reduced excess capacity through mergers and reconfiguration of in-patient services. In health financing, it has established a separate State purchasing agency and undertaken provider payment reform, including the recent introduction of performance-based contracting for primary care doctors. As with efficiency gains, other factors that could explain improved performance of the health system include the existing capacity of medical personnel and/or public health officials along with existing technology and the quality of drugs and equipment. Two decades of investment in health infrastructure, human resources, and equipment capacity provided a critical support to the Government in modernizing health service delivery in the country.

Figure 3. Efficiency Scores, Total Health Spending, and Share of Private Sector Health Spending

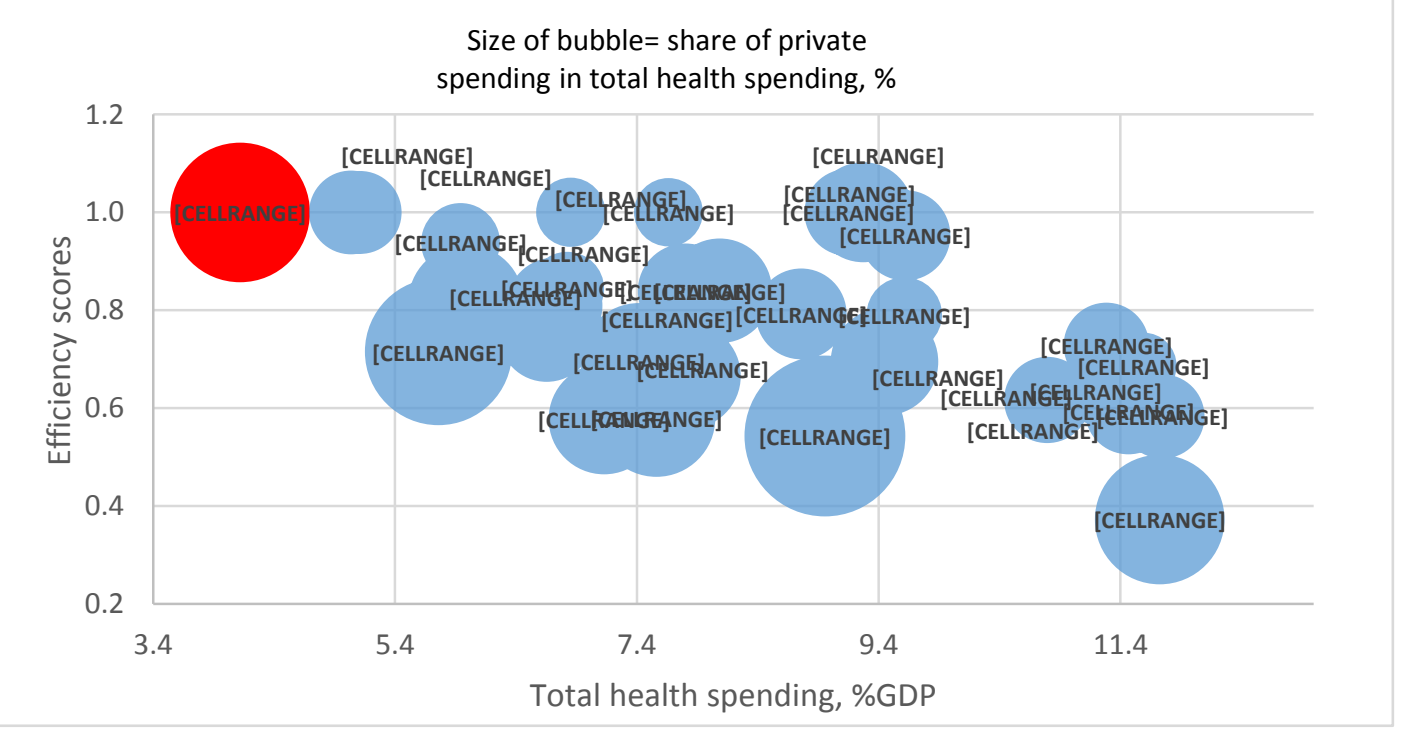

Source: Boost data base

\section{Education}

1.16. In the education sector, Armenia spends approximately 1 percent less than the LMIC average and around 3 percent less than the CIS and EU averages. Armenia spent 2.4 percent of GDP, compared to 3.5 percent spent by LMICs, 5.3 percent by CIS countries, and 5.2 percent by the EU countries. Further drill down on spending by levels of education show that Armenia spent 16 percent per pupil as a percent of GDP per capita in primary education, more than the 14 percent spent by LMICs and far less than the 24 and 23 percent spent by the CIS and EU countries, respectively (Figure 4). In secondary education, Armenia spent 18 percent per pupil as a percent of GDP per capita, which was the same as the amount spent by LMICs but less than the 25 and 28 percent spent by the CIS and EU countries, respectively (Figure 5). 
1.17. Relatively low per capita spending is associated with relatively good outcomes compared to CIS and LMIC group averages. In terms of the "adult literacy rate," Armenia far outperforms LMICs and is on par with both CIS and EU countries. In terms of the "net secondary enrollment ratio," Armenia outperforms LMICs, is on par with CIS countries, and is lagging behind the EU countries. In terms of "lower secondary completion rate" and "tertiary gross enrollment," while Armenia performs better than LMICs, it lags behind both CIS and EU countries. Finally, TIMSS scores for math and science for grades 4 and 8 show that while Armenia performs slightly better than CIS countries in math, it lags behind in science.

\subsection{The better than average education sector spending efficiency could partly explain the} positive results. An efficiency analysis of the sector using DEA on the sector revealed that with an efficiency score of 0.66 and 0.75 respectively, Armenia's efficiency in primary and secondary education spending although not among the most efficient, is above average compared to other countries in the sample. Given that Armenia's government spends more than 65 percent of its education budget on primary and secondary education, improving spending efficiency in these two sub-sectors is important. ${ }^{5}$ In addition, the education sector benefited from externalities from social protection sector spending. The 2014 PER found that implementation of social assistance programs, such as the means tested Family Benefits Program (FBP), have played an important role in reducing poverty and have contributed to human capital development. Among households below the upper poverty line, family benefit recipients spend almost three times more in education than non-recipients do.

\footnotetext{
${ }^{5}$ For the single-input, multiple output secondary education DEA, the sample included 4 CIS and 14 EU countries. The input variable is "secondary education per pupil spending." The outcome variables used are "secondary net enrollment, \%" and "lower secondary completion rate." For the single-input and output primary education DEA, the same included 4 CIS and 25 EU countries. Input data are from 2012 and outcome data are the latest available. The source for Armenia's public expenditure is BOOST and all the rest are from Education Stat.
} 
Figure 4. Efficiency Scores for Primary Education

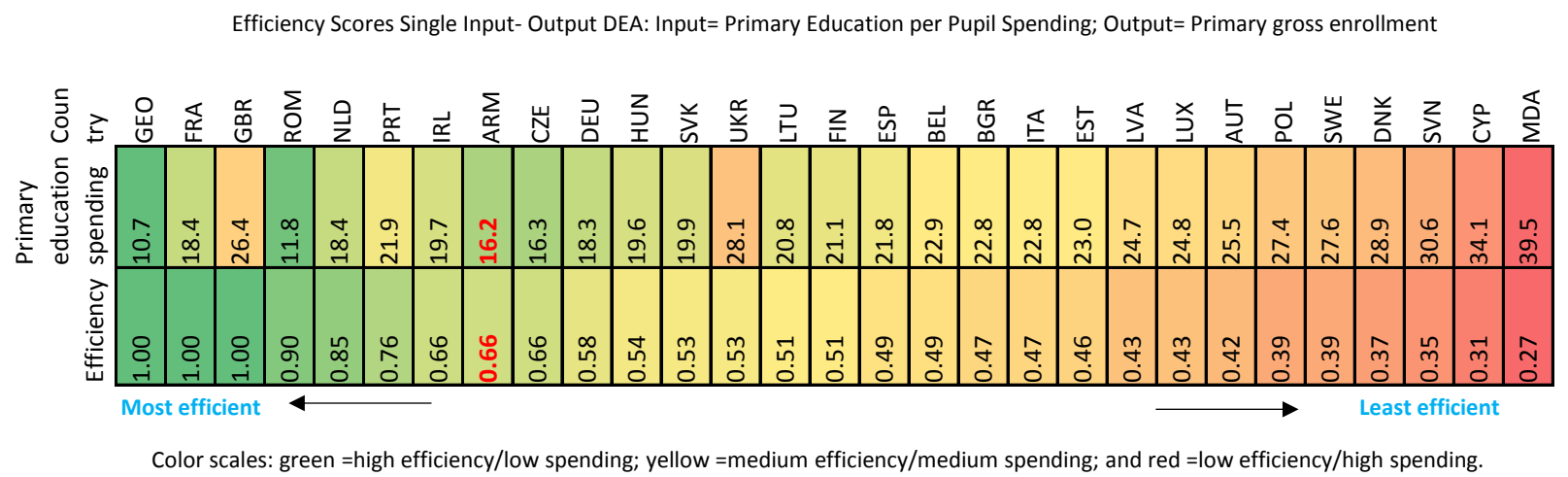

Figure 5. Efficiency Scores for Secondary Education

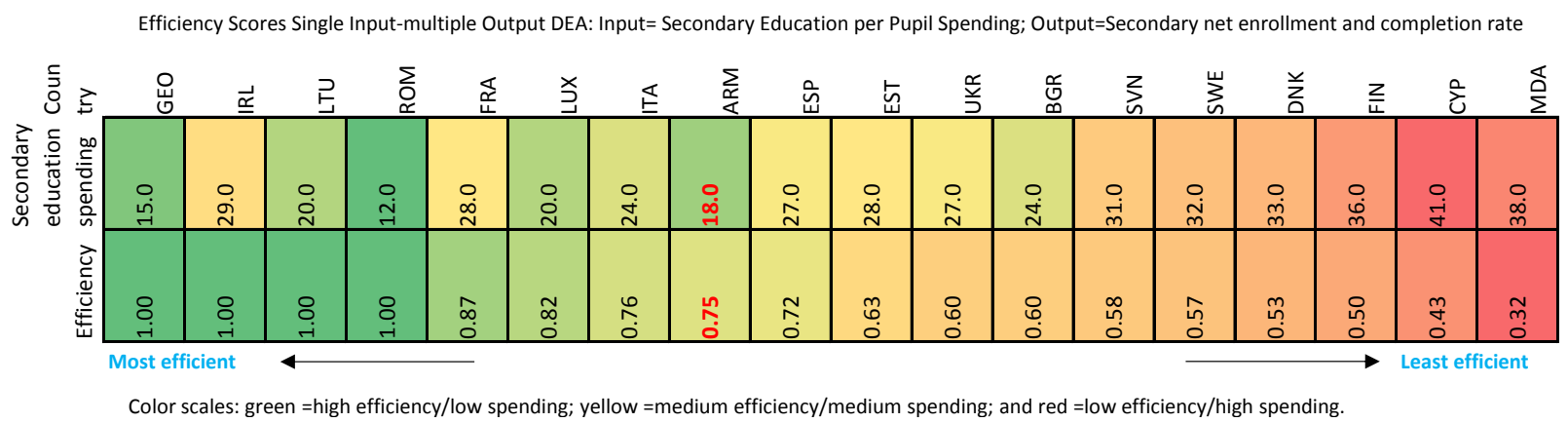

\section{Social Protection}

1.19. In the area of social protection, Armenia's per capita spending is low compared to CIS and EU countries, but yields better outcomes relative to the CIS group average. While Armenia spends 2.4 percent more than LMICs, it lags behind both CIS and EU countries by about 4 and 10 percent, respectively. In terms of outcome indicators as measured by the HDI and Gini coefficient, Armenia's performance lags behind EU countries in terms of the HDI but is on par in terms of the Gini index. Armenia performs better than CIS countries in terms of the HDI and is on par in terms of Gini index. Armenia performs better than CIS in terms of HDI and is on par in terms of Gini. Armenia performs better than LMICs in both indicators.

1.20. A similar efficiency analysis using DEA produced an efficiency score between $0.5-0.6$, which is slightly below average. However, the 2014 PER documents that even with some of the administrative inefficiencies that exist in the social assistance programs, overall Armenia's social protection system is effective in reducing poverty. If these results can be proven consistently, then it seems that Armenia has managed to achieve comparable results with less spending and, at least in the health and education sectors, this is achieved partly through efficient spending. 


\section{Capital Spending}

1.21. The level of capital spending matters, as does the quality. Armenia's low levels of capital spending do not necessarily imply a poor quality of infrastructure, which is common among many transition countries. At about 3 percent of GDP in 2015, Armenia's public capital spending, given its overall quality of infrastructure, places the country somewhere in the middle between most ECA transition countries and some Western European countries, which typically report better quality infrastructure and also spend comparably less on capital (Figure 6). However, the quality of infrastructure will undoubtedly deteriorate if underfunding continues in the longer term.

1.22. The same conclusion could be drawn by contrasting the overall level of capital spending and the quality of roads. Again, Armenia's public spending seems to be more efficient when compared to other countries in the ECA region, but still requires further improvements when compared to more advanced European economies (Figure 7). Given that about one-third of the capital envelope in Armenia is absorbed by the construction of roads, this fact cannot be neglected. Nevertheless, the results should be treated with some degree of caution for two main reasons. First, investment projects typically involve longer planning horizons, which span over many years. Second, the effect of public spending on the quality of infrastructure could be lagged dependent. With this in mind, perhaps a longer time in the case of capital spending might be preferred when analyzing the quality of infrastructure.

Figure 6. Efficiency of Capital Spending in a Selection of ECA and EU Countries: Overall Quality of Inf rastructure, 2012/2013

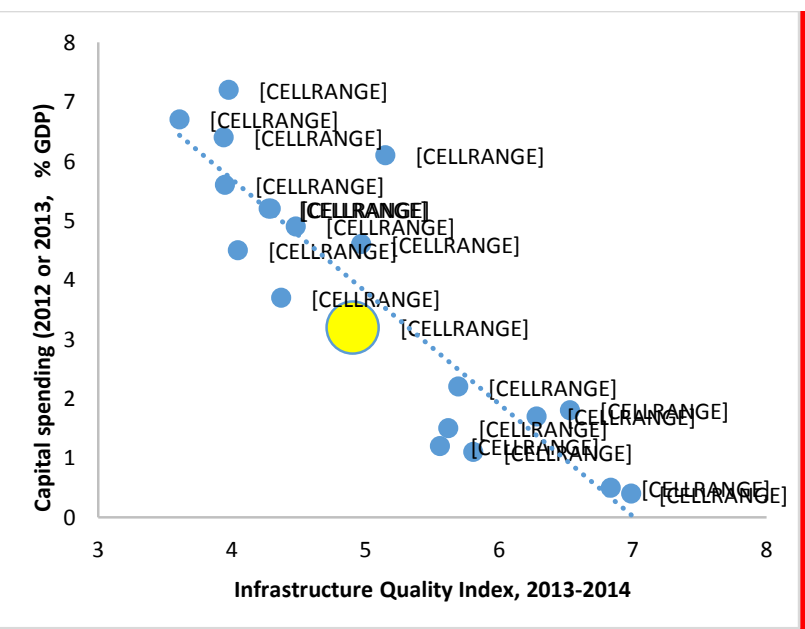

Source: WB staff calculations based on WEO and the Economic Forums' Golbal Competitiveness Report, 2014.

Note: The quality of overall infrastructure ranges from 1 to 7 (best).

1.23. Countercyclical fiscal policy is an important macro risk management tool; however, Armenia's government spending shows high pro-cyclicality. Countercyclical spending is 
desirable because it can transfer resources to less favored individuals, and it can serve to stimulate real economic activity in the event of shortfalls in aggregate demand. In particular, during the recent financial crisis, social spending and stimulus packages have been used by many countries to protect individuals during periods of hardship and to stimulate employment. However, with a 31 percent correlation with the cyclical component of GDP from 2005 to 2013, Armenia's government spending is clearly pro-cyclical. In contrast, many industrial countries have countercyclical fiscal spending (Figure 8). For example, the correlation of the United States' public spending is $\mathbf{- 9 4}$ percent. Countercyclical fiscal policy is particularly important for Armenia because the alternative policy option - monetary policy_-is quite weak in a highly dollarized market.

Figure 8. Correlations between Cyclical Components of Real GDP and Government Spending, 2005-2013

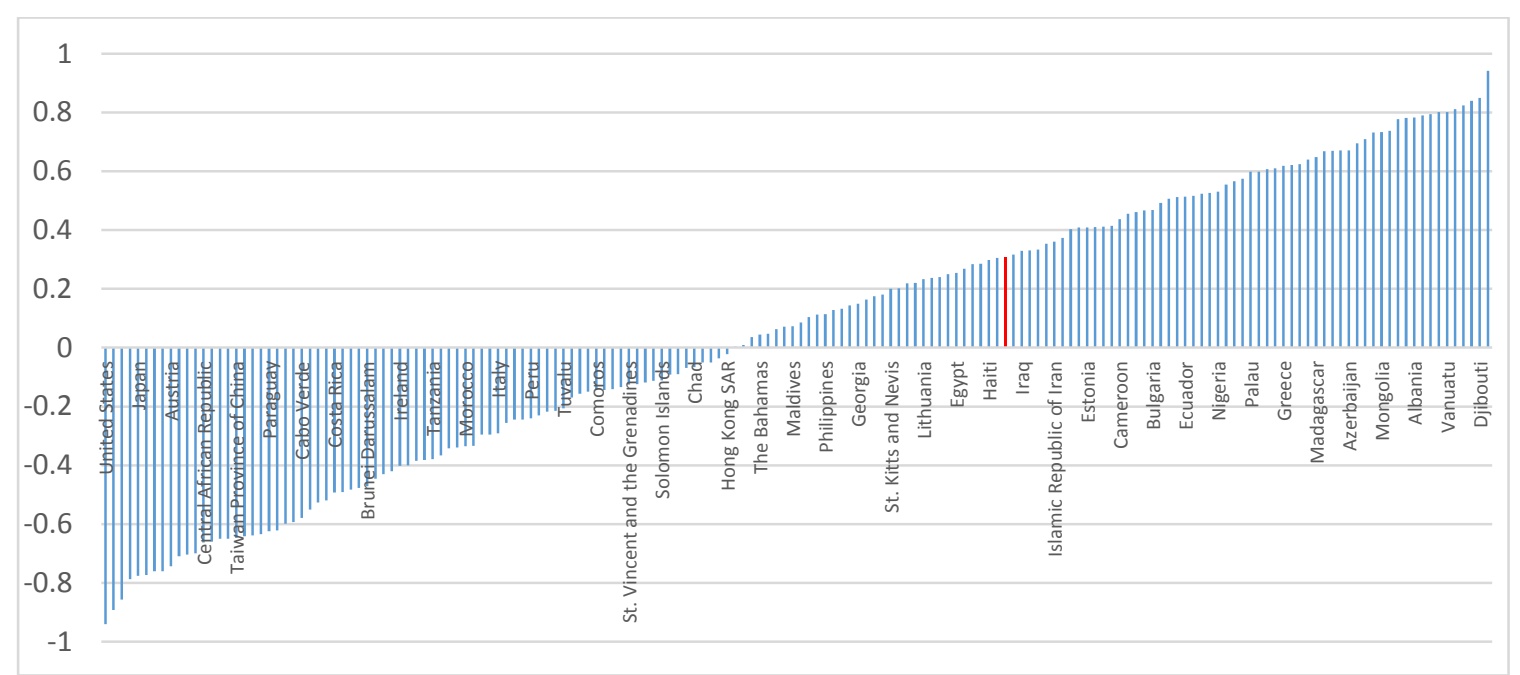

Source: WEO, 2005-2013.

1.24. Public investment in Armenia remains small and has been contracting as a percent of GDP. In the 1996-2015 period, public investment in Armenia averaged about 4-5 percent of GDP and less than 20 percent of total investment in the economy (Figure 9). However, since 2012 public investment has been reduced to below 3 percent of GDP. It is lower than the average of developing

Figure 9. Public Investment in Armenia

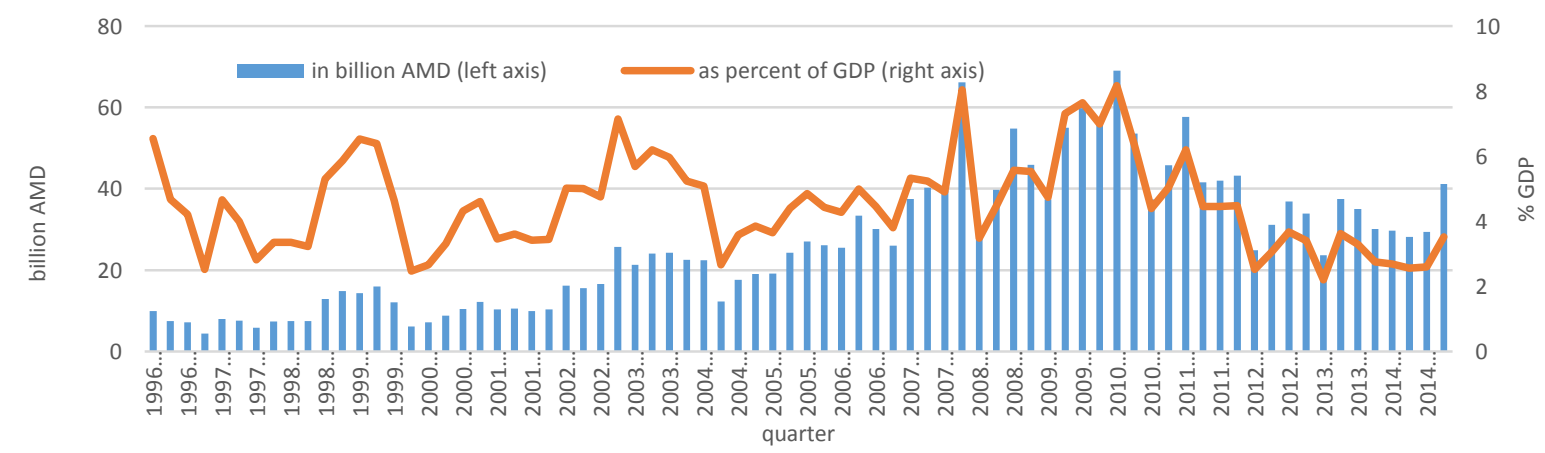

Source: Bank staff calculation and Armenian authorities.

Note: Seasonally adjusted quarterly GDP and investment series. 
economies (4.4 percent of GDP) and ECA countries (4.3 percent of GDP) for 2012-2015. The low public investment in recent years was mainly due to delays in implementation that led to capital budget under-execution.

\section{Box 1: Public Investment and Growth}

Theoretical and empirical work supports a positive linkage between public investment and economic growth. Investment and accumulation in capital is known as a key driver of economic growth. Specifically on public investment, Barro (1990) showed a positive linkage between public investment and growth in a theoretical framework where public investment is complementary to private investment. In the long term, public investment raises total capital stock and expands the productivity capacity of the economy. In the short term, like other government spending, an increase in public investment can stimulate the economy through fiscal multipliers. Empirical studies find that government investment is growth-enhancing in the United States (Aschauer, 1989) and advanced economies (Kneller et al., 1999; Abiad, et al., 2015). A recent survey of related literature showed that the output elasticity of public capital averages 0.106 (Bom \& Ligthart, 2014). In addition, shocks from public investment are found to have statistically significant and long-lasting effects on output using a sample of 153 economies: in general, an unanticipated 1 percentage point of GDP increase in public investment raises the level of output by about 0.4 percent in the same year and by 1.5 percent four years after the shock (IMF, 2014). Moreover, higher public investment could raise the productivity of private investment and "crowd in" private investment; new evidence has emerged to support the "crowding in" effect of public investment in developing countries (Eden \& Kraay, 2014).

In the presence of a substantial infrastructure gap, many developing countries face large potential gains from raising public investment. Among developing countries where capital stocks are relatively low, countries with higher public investment are associated with faster economic expansions (Gupta et al., 2005). And in the current environment of low real interest, increasing public investment appears to be particularly appealing. However, despite potential gain from public investment in developing countries, the size of impact varies with a number of factors, including the degree of economic slack and the efficiency of public investment. In general, increasing public investment has a larger impact in the cases when infrastructure need is clearly identified, public investment processes are efficient, and in an economic slowdown when GDP is below potential output (IMF, 2014).

Different models show evidence of a positive impact of public investment on final output, but results vary among the different methodologies. A simple vector autoregressive (VAR) analysis on a quarterly series yields a positive growth response from an increase in investment (Figure 10). A 1 percent increase in total investment in GDP would contribute to an increase of about 0.35 percentage points in real GDP growth in the next quarter, and the effect gradually diminishes in the course of two years. Based on a structured vector autoregressive (SVAR) model, fiscal multipliers were 0.21 for contemporaneous impact and 1.12 after one year (IMF, 2015). Simulations from a structural model estimated that returns from government investment 
are high for Armenia (Eden \& Kraay, 2014).

Figure 10: Public Investment (\% GDP) and GDP Per Capita

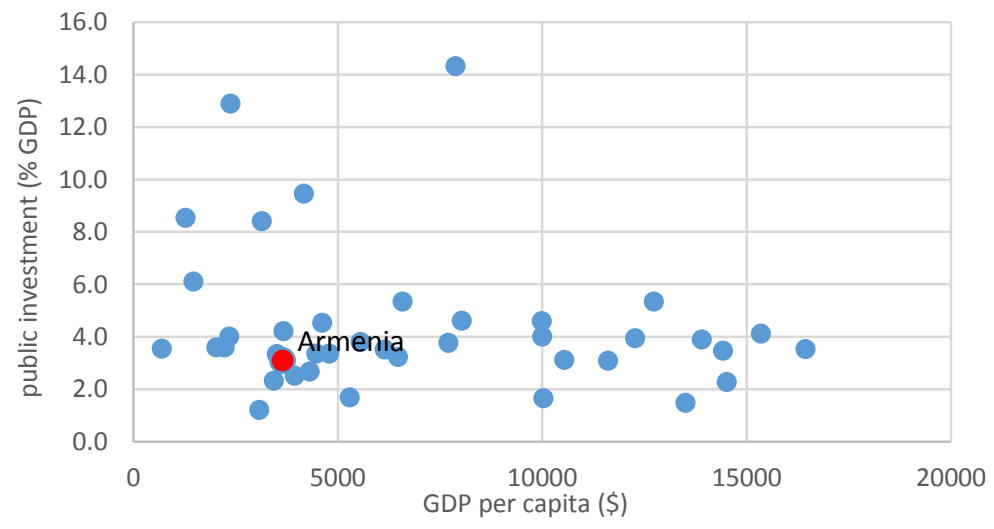

Source: IMF GFS and World Bank WDI.

Note: public investment is the average over 2012-2014 and the GDP per capita is of 2014, or 2013 if not available in 2014.

A persistent infrastructure gap, low public investment, and high potential returns highlight the importance of government investment in Armenia. Proper execution, good design of capital projects, investment efficiency, and the timing of investment are the key factors in maximizing the impact of public investment on the economy (Figure 11).

Figure 11: Response to 1 percent of GDP Increase in Public Investment
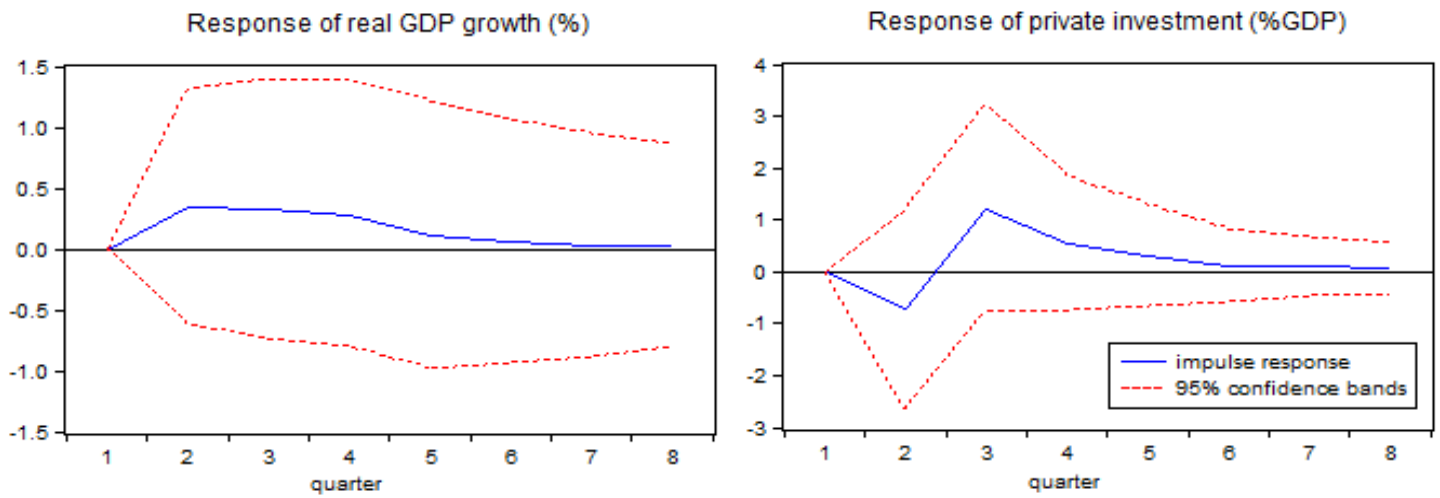

Source: Bank staff calculation and Armenian authorities.

Note: VAR includes two lags of real GDP growth, private investment (\% of GDP), and public investment (\% of GDP). 


\section{Recent Fiscal Developments and Trends}

1.25. Armenia's budget is low relative to the size of the economy. At around 25 percent of GDP in recent years, Armenia's general government spending is smaller than that in LMICs, CIS countries, and EU countries, due mainly to the limited ability to raise government revenues. Indeed, Armenia's tax-GDP ratio, an average 22 percent of GDP for the same period, is also among the lowest in the ECA region (Figure 12).

Figure 12. Income Level and Government Spending, 2012

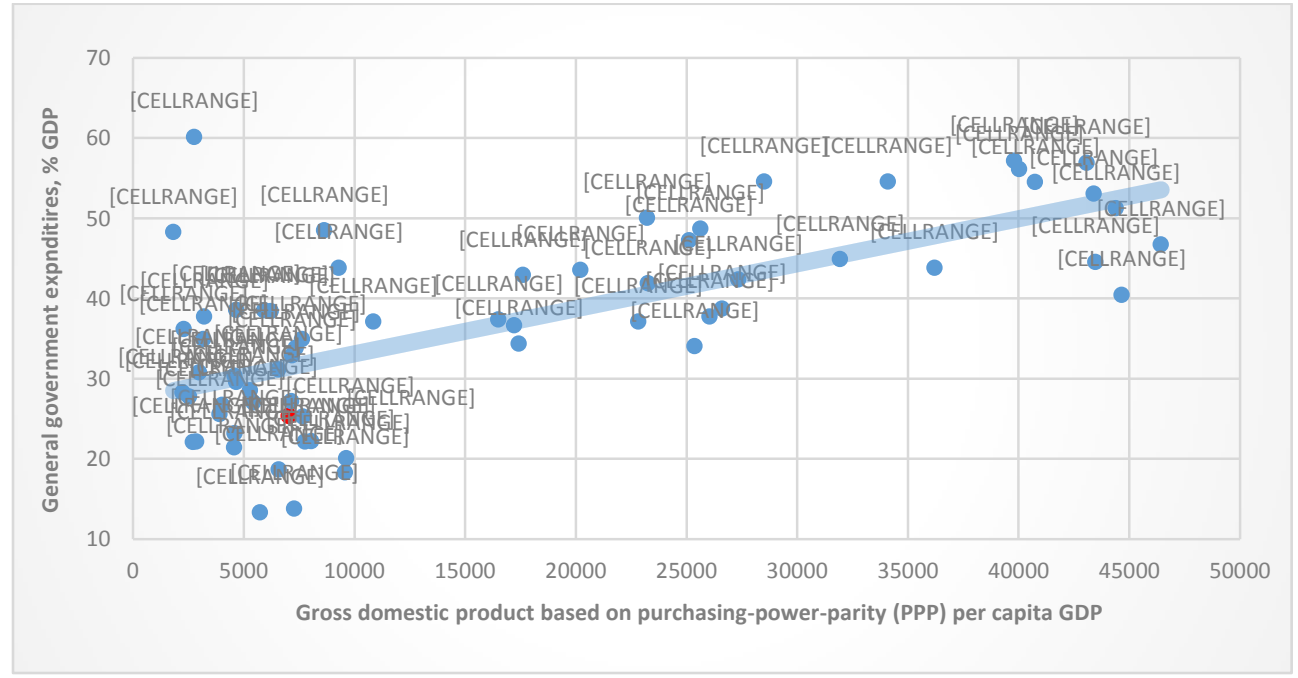

Source: IMF WEO Database

1.26. Armenia's fiscal consolidation, carried out between 2009 and 2014, was among the most ambitious in the region. In 2009, the country's fiscal position deteriorated sharply, with the fiscal deficit soaring from 1.7 percent of GDP the previous year to 7.7 percent (Figure 13). The increase in the fiscal deficit was attributed mainly to greater budgetary allocations toward social protection and economic sectors, an increase of 1.8 percentage points each between 2008 and 2009. From 2009, a broad-based expenditure downsizing was the main driver of the consolidation effort. The spending cuts disproportionally affected almost all expenditure items, with the public investment programs withstanding the worst of the adjustment. Between 2011 and 2012, and later 2013 and 2014, fiscal consolidation evolved somewhat faster than expected, mainly because of the under-execution of capital expenditures, which dropped from about 7 percent of GDP in 2009 to 2.3 percent in 2014. Instead, since 2009 current spending was scaled up by 1.3 percentage points of GDP as of 2014 and by 4.2 percentage points if compared to 2008. At the same time, substantial progress was achieved in terms of revenue collection, which saw an increase of above 2 percentage points of GDP between 2009 and 2013. 
1.27. The deteriorated external environment in 2015 led to substantial negative spillovers on the Armenian economy despite the higher than expected growth outcome. On the one hand, fiscal revenues fell short by 0.5 percentage points of GDP; on the other hand, the government implemented a fiscal package to stimulate economic activity and consumption, which widened the fiscal deficit to 4.8 percent of GDP from about 2 percent the previous year. Against this backdrop, in order to balance the pace of medium term fiscal consolidation, the deficit is projected to lower to 4.1 percent in 2016 with an understanding that it will converge to below 3 percent in 2018. Meanwhile, in the context of dried out external financing and limited borrowing capacity, fiscal consolidation is expected to materialize through an improved domestic revenue mobilization effort supported by the unified tax code. Following up on the recommendations of the 2014 PER, the government envisaged significant tax policy changes in the unified tax code (rationalizing the VAT threshold, bringing agriculture into the VAT net, reducing the scope of tax exemptions, introducing dividend taxation, and increasing the excise rates on compressed natural gas, alcohol, and tobacco) and tax administration (introduction of treasury accounts for all taxpayers, introduction of a more transparent tax refund system, and monitoring of transfer pricing mechanisms), which are expected to increase fiscal revenues by about 2 percentage points of 2015 GDP (in net basis) between 2017 and 2021.

1.28. Efficiency of public spending matters, but a limited fiscal space restricts the government's ability to impact the economy and improve social welfare. This suggests that the government needs to rationalize expenditure allocation, improve efficiency of spending, and increase revenue mobilization to reduce poverty and boost shared prosperity. While the general public expenditures envelope increased by more than 5 percent during the 2012-2015 period and reached 29.4 percent of GDP in 2015, the upward spending revisions were spread over all major economic items, with social transfers, the acquisition of goods and services, grants, as well as labor costs (salary increases for civil servants) absorbing the brunt of the adjustment. Increasing by 1 percentage point of GDP, social allowances and pensions accounted for the largest fiscal increases. At the same time, interest payments surged from 1.0 percent of GDP in 2013 to 1.5 percent in 2015, due in part also to the devaluation of the local currency. Subsidies also picked up, reaching 0.7 percent of GDP. In 2015, capital spending increased for the first time since 2009, reaching 2.9 percent of GDP, as authorities made efforts to improve the execution of the capital budget. 
Figure 13. Expenditures, Revenues, and the Fiscal Deficit (\% GDP)

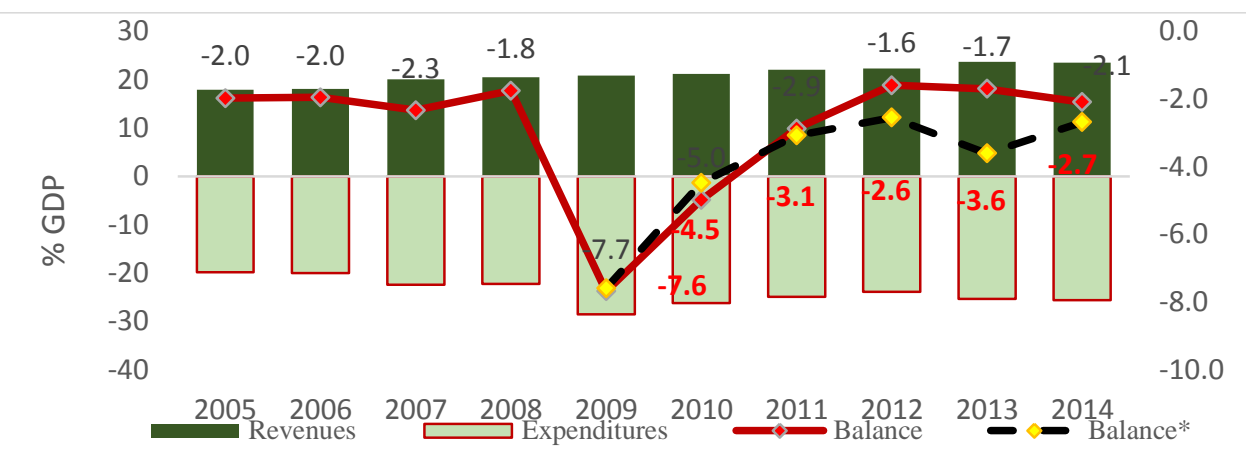

Source: World Bank (WB) staff based on the IMF World Economic Outlook (WEO).

Note: $*=$ Estimated fiscal balance corresponds to the fiscal deficit/surplus under the full execution of capital spending. 1.29. Welfare-enhancing expenditures, such as education, health care, and social protection, were higher in 2015 than in the previous year. Between 2013 and 2015, the social protection outlay saw an increase of 1.1 percentage points of GDP. Education and health care expenditures were also adjusted upwards, with increases of 0.1 and 0.3 percentage points accordingly. Growth in spending on general public services continued in 2015, growing on average by 0.6 percentage point over the 2012-2015 period. Spending on economic affairs averaged 2.2 percent of GDP in 2015, down from 2.8 percent in 2013, when the upward revision was brought by a one-off payment for gas (about 1.4 percent of GDP in 2013).

Figure 14: Central Government Expenditures by Economic Classification, 2008-2015

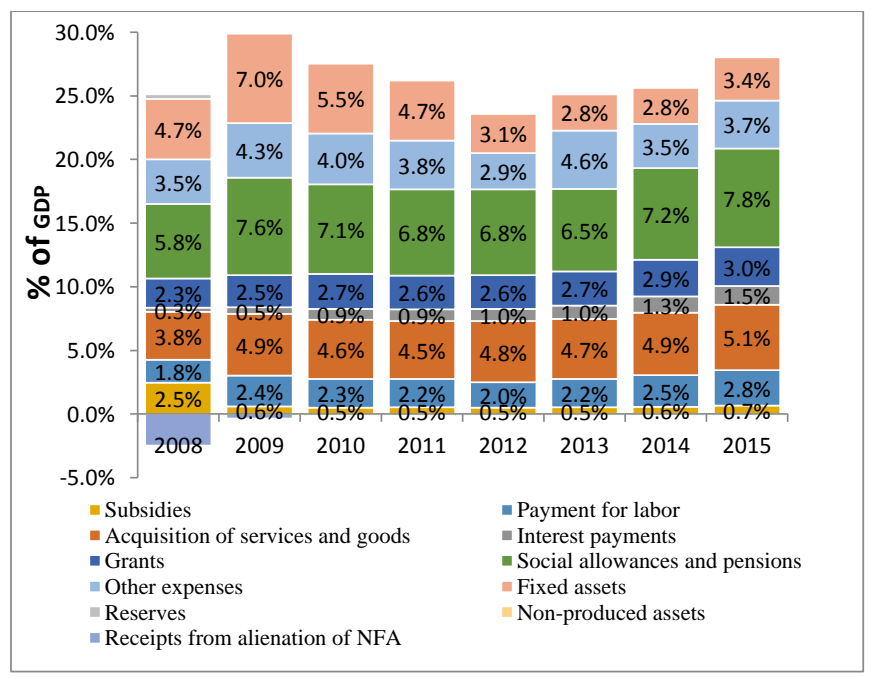

Source: WB staff calculations based on BOOST.
Figure 15: Central Government Expenditures by Function, 2008-2015

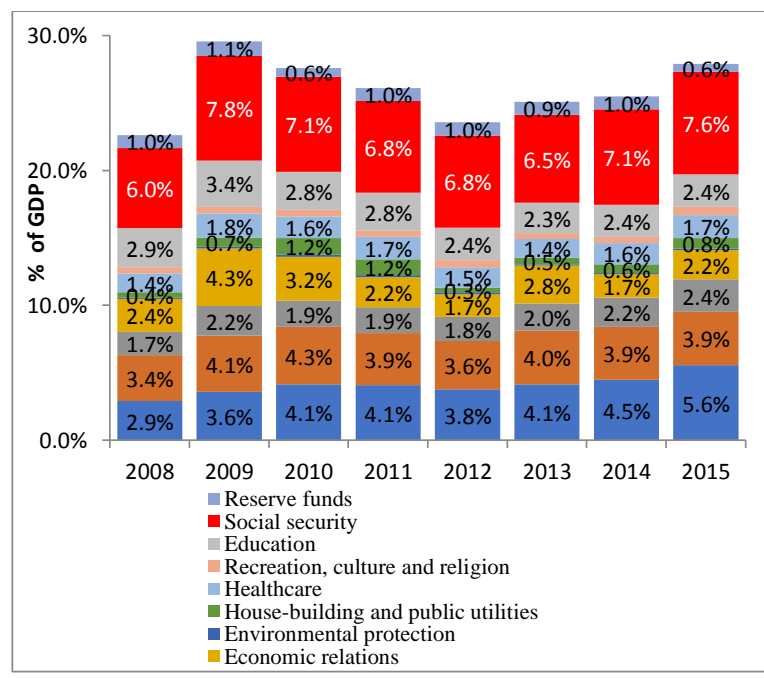

1.30. Public spending on social protection is a major source of fiscal pressure in Armenia. More than two-thirds of the sectoral envelope has been redistributed toward the functional group for old-age social spending, which slightly expanded in 2014, both as a share of total social protection spending (from 67 percent in 2013 to about 70 percent in 2014) and as a share in GDP (an increase of 0.4 percentage points). About 80 percent of the old-age function expenditure was 
allocated toward pensions. As the authorities proceeded with the implementation of pension reform, pension-related spending grew by ARM 28.8 billion or 15 percent in nominal terms between 2013 and 2014. The family and children function is the second-largest recipient of budgetary resources in the social protection category, driven mainly by the Family Benefit Program (on average, 0.8 percent of GDP, year-on-year), followed by maternity benefits and childbirth grants, which have been on the rise since 2009 (average of 0.24 percent, year-on-year). Meanwhile, unemployment benefits continued to be scaled down, in line with the government objectives in the sector. The housing (settlement) expenditure was also scaled down substantially, reflecting the phasing out of public support related to the earthquake of 1988. Other services provided under the social protection rubric have expanded substantially over the past three years - 0.3 percent year-on-year-driven by an increase in spending on social packages for public sector employees.

1.31. Since 2009, the health budget has become more skewed toward in-patient services. On average, total health care spending (as a share of GDP) seems to be on par with Central Asian countries, which tend to relatively underspend on health (on average, 1.8 percent of GDP in 2013) when compared to other regional peers (on average 4 percent of GDP that same year) and EU countries (on average, 7.8 percent of GDP in 2012 and 14.9 percent of total government spending). As in the previous years, the government continued to squeeze capital expenditures, which now account for only 5 percent of the total sectoral budget. Compared to 2013, general hospital expenses were scaled up in 2014, in response to a set of health reforms aimed at modernization of the country's health care system.

1.32. After a sharp decline over the 2009-2013 period, education spending seemed to slightly recover in 2014. About 46 percent of the sectoral budget was allocated toward general secondary education, followed by pre-school and general elementary education ( 21 percent in 2014), vocational (6.4 percent) and higher education ( 8.2 percent), with the other services provided in education (mainly auxiliary services) absorbing the residual 19 percent of the budget. The year 2014 was marked by an upward revision in the budgetary allocations, fueled by greater capital spending on construction/reconstruction of buildings, and marginally by increased student allowances in vocational and higher education.

1.33. Chronic under-execution of the capital budget has been an issue since the crisis hit in 2009; however, indicators improved in 2014. The 2014 year-end total capital budget execution was about 80 percent, up from a low of 60 percent in 2013. Notably, evident progress was achieved in the case of the economic affairs outlay, which experienced a substantial under-execution of its capital budget in 2012 and 2013: 53 percent (1.01 percent of GDP) and 68 percent (1.48 percent of GDP), respectively, against the approved capital budget. However, capital expenditures in health care (with a capital execution rate of 38 percent) and education ( 52 percent) continued to be heavily under-executed, hampering the quality of the capital stock and service delivery in these important sectors. In contrast, capital investment in public order has been persistently over-executed since 2009. 
Figure 16. Central Government Spending (million AMD) and Deviation from Budgeted Amounts $(\%)$
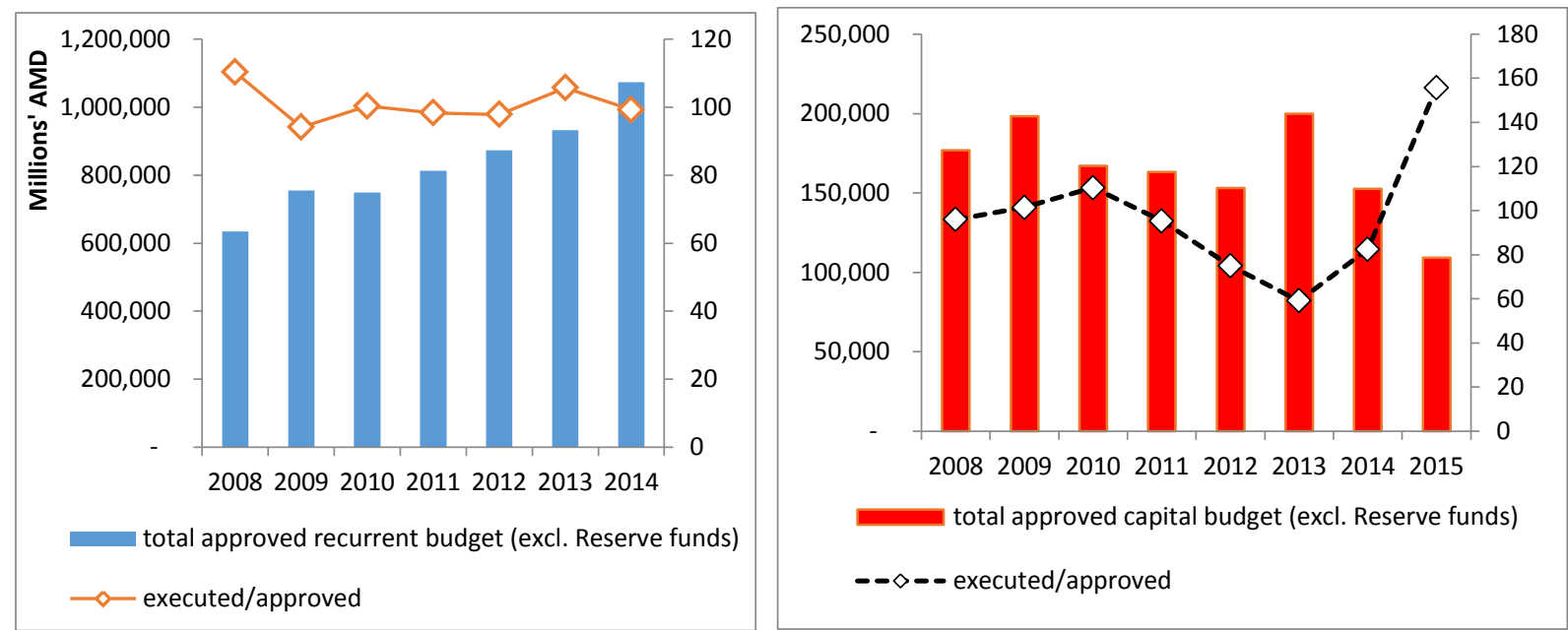

Source: WB staff calculations based on BOOST.

1.34. The brunt of the capital adjustment was absorbed by economic relations expenditures. Capital spending under in this category declined from a high of 3.5 percent in 2009 to a low of 0.9 percent of GDP in 2014 (see Figure 17, right panel). A broad-based capital contraction affected education (a decline of 0.3 percentage points) and public order and safety (a decrease of 0.2 percent). At the same time, capital spending in general public services as well as housing and communal services was more protected over the same period.

Figure 17. Capital Adjustment by Type of Expenditure (left panel) and Sector (right panel), $2009 / 2014$
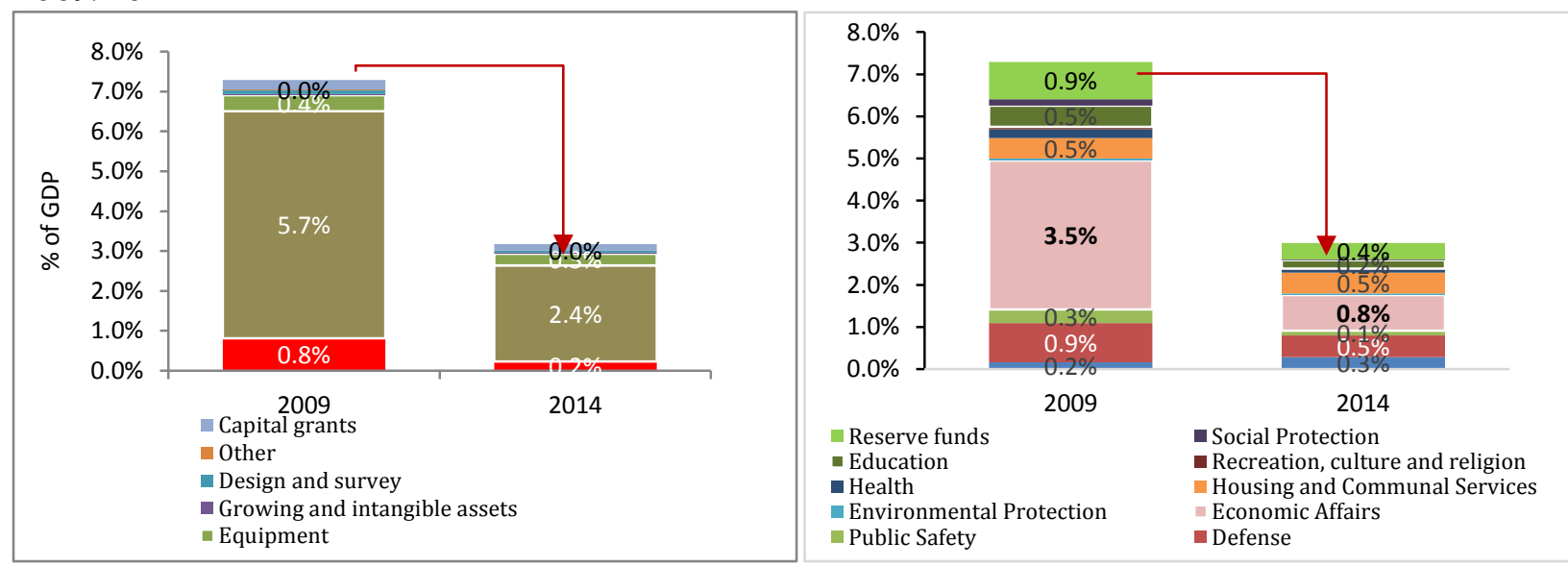

Source: WB staff calculations based on BOOST. 


\section{Taxation}

1.35. Armenia's tax collection increased sharply in recent years, from 16.5 percent of GDP in 2009 to 22.8 percent in 2014. Currently, about 97 percent of total revenue comes from taxes. The value-added tax (VAT) is the main source of revenue, accounting for about half of the tax revenues. Income tax, which reached 6.4 percent of GDP in 2014, was the next important category; it included social security contributions as of 2013. Higher revenues were driven by a turnover tax introduced in January 2013. Meanwhile, collection of presumptive taxes (i.e. on petrol and diesel fuel and on domestically produced and imported cigarettes) decreased substantially over the past 6 years from a high of 2.1 percent of GDP in 2009 to about 0.1 percent in 2014, as the authorities intensified efforts toward a unified tax regime.

1.36. Tax administration is an important element of fiscal management and, if implemented effectively, it may contribute to the overall efficiency of public resource management. Notwithstanding Armenia's recent tax policy and administration improvements, tax collection has been accompanied by piling-up tax prepayments and tax credits. Over the 2012-2015 period, the outstanding stock of overdue tax commitments by taxpayers (tax arrears) increased by 20 percent, to AMD 120 million, and stood at about 2 percent of GDP in 2015. A portion of this consists of unmet tax commitments of bankrupt or non-performing companies carried on from one year to another; to ascertain the origin of the remaining portion, further analysis is required. On the other hand, the stock of tax credits (the state budget's commitments to the taxpayers in the form of advance receipt of tax payments, due VAT refunds to exporters, etc.) has been increasing over time, reaching 5.2 percent by the end of 2015. As a result, the private sector implicitly subsidized the state budget, providing a net indirect subsidy of over 3 percent of GDP until 2014, and subsequently of 2.8 percent of GDP (2015). These tax credits could potentially be legitimately claimed and offset against taxpayers' future tax obligations, which will then require significantly higher tax collection and revenue mobilization efforts by the government to balance the net effect.

Table 4: Central Government Tax Arrears, 2012-2015 (billion AMD)

\begin{tabular}{|l|r|r|r|r|}
\hline & 2012 & 2013 & 2014 & 2015 \\
\hline Tax arrears (end of year) & 100.1 & 102.7 & 114.0 & 120.5 \\
\hline Tax Credits (end of year) & 234.7 & 254.7 & 258.7 & 262.7 \\
\hline Net tax arrears & -134.6 & -152 & -155.3 & -142.2 \\
\hline GDP (nominal) & $4,266.0$ & $4,556.0$ & $4,828.6$ & 5032.1 \\
\hline Net tax arrears, \% of GDP & $-3.2 \%$ & $-3.3 \%$ & $-3.2 \%$ & -2.8 \\
\hline
\end{tabular}

Source: Ministry of Finance

1.37. Tax rates and tax administration are both perceived to be the major obstacles to doing business in Armenia. According to the 2013 round of the Business Environment and Enterprise Performance Survey (BEEPS), tax rates and tax administration are both identified to be the main obstacles to doing business in the country (see Figure 18). 
Figure 18. Top 10 Obstacles to Doing Business in Armenia, 2013

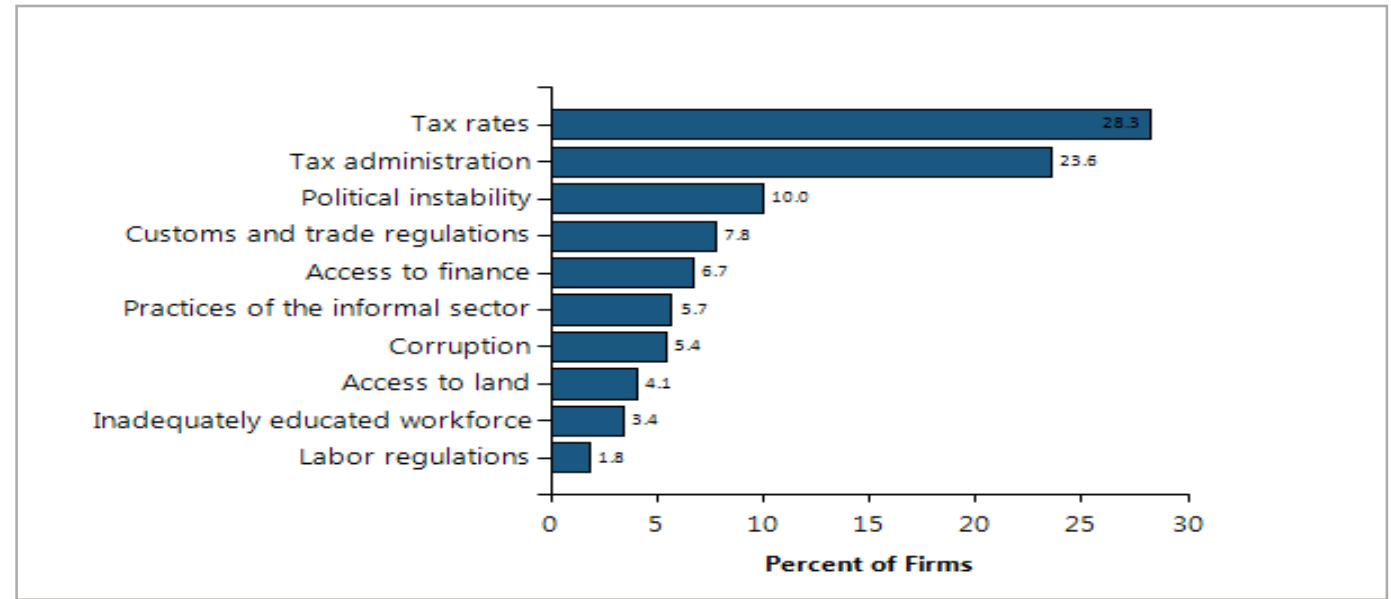

Source: 2013 Armenia BEEPS data.

1.38. Armenia's performance in terms of taxes and tax administration is also below par when compared to other regional peers and the world average, perhaps being outpaced only by Romania (for both tax rates and tax administration) and Ukraine (tax rates only). Accordingly, about 37 percent of firms in Armenia perceive taxes as an obstacle to doing business, which is much higher than the ECA average of 24 percent and the worldwide average of 31 percent (Figure 19, left panel). The same holds true for tax administration, which 29 percent of Armenian firms view as a constraint for doing business in the country compared with, on average, 14.8 percent of firms in the ECA region and 21.2 percent in the world as a whole (Figure 19, right panel).

1.39. High tax rates, poor tax capacity, doubts about fairness of taxation, and transparency in terms of resource allocation are potential causes of dissatisfaction with the current tax system in the country. According to the Tax Perception Report ${ }^{6}$, about one half of the respondents believe only 0-20 percent of the revenue collected to be spent on public services. At the same time, about 76 of the respondents agree with the theory of the Laffer curve, according to which a lower tax burden increases the amount of taxes collected by the government. Overall, there is a broad consensus among the respondents that the tax load is "heavy" or "too heavy." On the positive side, there is some indication of appreciation for the improvements in the tax services (as it was found in the case of the electronic services).

\footnotetext{
${ }^{6}$ For more information, consult "Tax Perceptions in Armenia Household and Enterprise Survey 2013". http://www.crrc.am/hosting/file/_static_content/projects/Tax\%20Reform\%20Project/TRP_Report_Eng.pdf.
} 
Figure 19. Percent of Firms Perceiving Tax Rates (left panel) and Tax Administration (right panel) as an Obstacle to Doing Business in Armenia, ECA, and the World
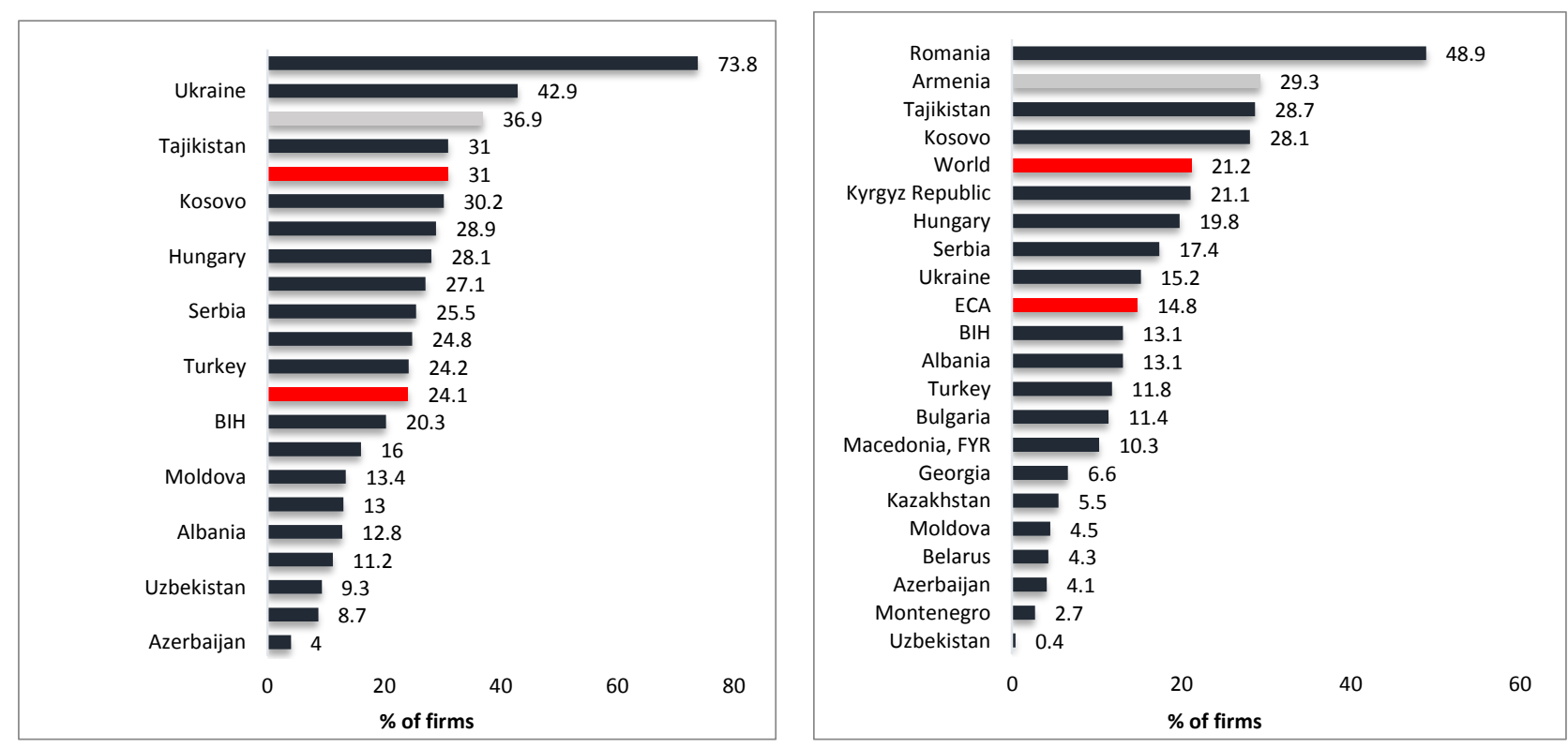

Source: BEEPS data.

Note: Regional and world averages are estimated by taking a simple average of country-level point estimates for the years 2009-2015.

1.40. Although the perception of the overall tax regime is still somewhat negative, recent progress in the ease of paying taxes and possibly in the efficiency of paying taxes cannot be neglected. Between 2011 and 2015, the Doing Business surveys for Armenia show that the average number of hours spent for tax compliance declined by 45 percent, from an average of 581 hours in 2011 to 321 hours in 2015. The number of tax payments has experienced an even more substantial decline (a fivefold decrease over the same period), averaging 10 payments per year in 2015. These developments, among others, were reflected in the country's relatively steep transition along the distance to frontier or best observed global practice (Figure 20), which compares Armenia's progress in terms of the ease of paying taxes to other economies covered by the Doing Business report (189 companies and selected cities). In the 2011 Doing Business report, Armenia scored only 4.1, implying their ranking is about 59 percentage points away from the frontier. In the 2015 Doing Business report, Armenia received 82 points, slightly above the ECA average of 75 . 
Figure 20. Ease of Paying Taxes (time and frequency) and Distance to Frontier in Armenia, 20062015

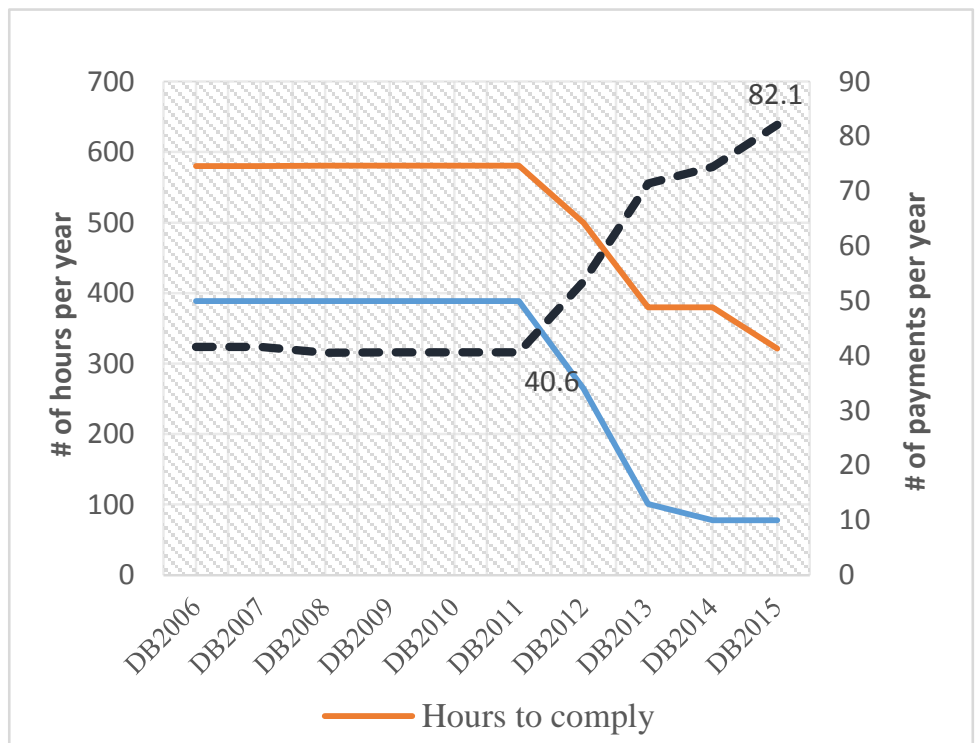

Source: World Bank Doing Business Survey, 2006-2015.

Note:The Distance to Frontier indicator shows how close each economy's performance (in this case, it is related to paying taxes) is to the best observed practices. An economy's Distance to Frontier is reflected on a scale from 0 to 100 , where 0 represents the lowest performance and 100 represents the frontier. 


\section{Chapter 2: Quasi-Fiscal Pressures in the Energy Sector}

\section{A. Financial Condition of the Power Sector and Potential Fiscal Implications}

2.1. During the 1998-2005 period, power sector reforms in Armenia produced remarkable results. The power sector of Armenia achieved remarkable results from the first generation of policy, legal, regulatory, and institutional reforms implemented between 1998 and 2005. The sector achieved financial sustainability with tariffs that assured full short-term cost recovery (i.e. the required operational and maintenance expenses; debt service; fuel costs; and return on the regulated asset base) and a collection rate that reached 100 percent of sales. The implicit and explicit subsidies to the sector were eliminated and the energy companies became among the top taxpayers in the country. A substantial share of Armenia's power sector assets has been privatized.

2.2. However, the power sector's financial performance has been deteriorating since 2010. As a result of several government actions and policies since 2010 , the financial stability of the power sector has worsened. These include: (a) non-core business related borrowing, lending, and expenses; (b) an inadequate mechanism for compensating exogenously caused losses of ENA; and (c) below cost-recovery tariffs for state-owned power companies. The analysis of the overall financial performance, liabilities, and their potential impact on the state budget is limited only to the state-owned power sector companies presented in Table 6 below.

2.3. The main objective of this chapter is to assess quasi-fiscal risks and contingent liabilities associated with the energy sector, reveal their causes, and propose policy recommendations to mitigate these risks. In the current context of a fiscally constrained macroeconomic environment, any additional burden stemming from the quasi-fiscal sectors may undermine the government's fiscal consolidation efforts and thus Armenia's medium- to long-term fiscal sustainability profile.

\section{Power Sector Overview}

2.4. Armenia's power system was unbundled in the early 2000 s to break up the vertically integrated energy utility company into independent electricity generation, transmission, and distribution companies. The GoA established the Electric Power System Operator (EPSO) and the settlement center. The power system is regulated by the Public Services Regulatory Commission (PSRC), an independent regulatory agency. The government also privatized a number of generation companies and the power distribution company, in addition to eliminating the explicit and implicit subsidies. Presented below is the summary description of key entities in the power sector and their responsibilities: 
- Generation: Independent companies providing capacity and energy services as per schedules agreed upon with EPSO and under the contracts with the power distribution company.

- Transmission: The state-owned High Voltage Electric Networks of Armenia (HVEN) maintains and develops the high-voltage electric network in the country.

- Distribution: The privately-owned Electrical Networks of Armenia (ENA) operates and develops the distribution network and is the single buyer of electricity in the country.

- System operation: EPSO manages the dispatch of power generation to meet both the domestic demand and the demand for exports.

- Settlement center: The settlement center conducts commercial settlements between electricity generators and the single buyer.

- Regulation: The sector is regulated by an independent regulator-the Public Services Regulatory Commission (PSRC) — which is responsible for tariff setting, service quality, and licensing.

Figure 21. Armenia's Power Sector Structure

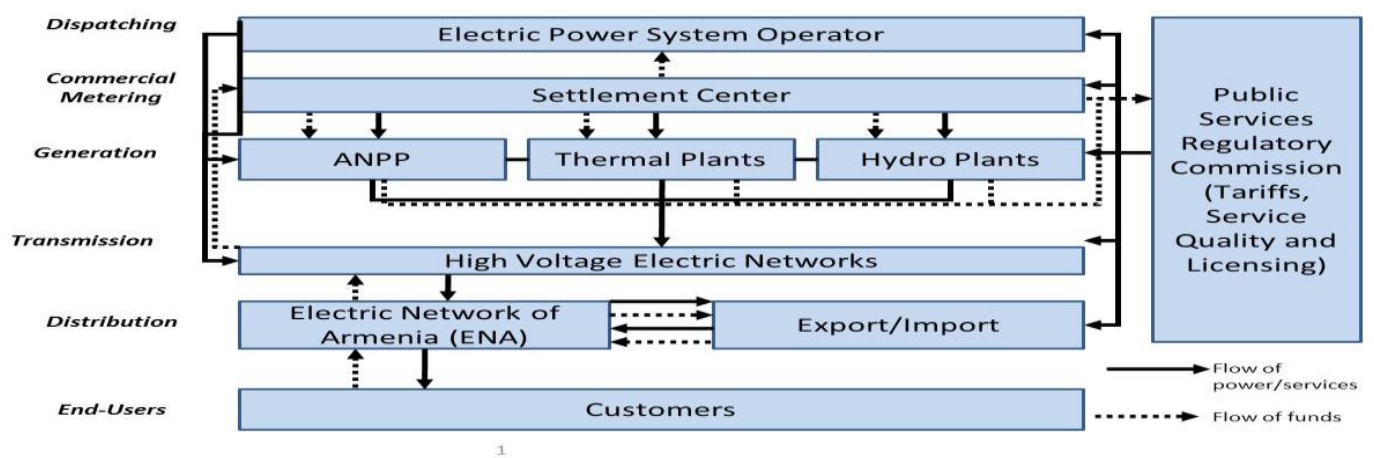

Source: "Armenia Power Sector Policy Note” - World Bank, December 2014.

2.5. The Armenian power system has 4,100 MW of installed generation capacity, which is comprised of nuclear, thermal, and hydropower plants. However, the installed capacity does not reflect the availability of many of the generating units given the technical disrepair, obsolescence, and environmental constraints in the case of one of the large hydro cascades - the Hrazdan HPP. With several generation units not in use due to extreme disrepair and thermal efficiency considerations, the operable generation capacity to meet the electricity demand is only 2,700 MW. Close to 1,000 MW of gas-fired thermal capacity is not operational due to age (50+ years) and very low thermal efficiency that yields exceedingly high-cost electricity. Moreover, the first 407 MW unit of the Armenian Nuclear Power Plant (ANPP) is not in service since 1988. As can be seen from Table 5, currently 80 percent of operable generation capacity is privately owned. 
Table 5. Main Generators and Ownership Structure

\begin{tabular}{|c|c|c|c|c|c|c|}
\hline Generator & Owner & Country & Type & $\begin{array}{l}\text { Installed } \\
\text { Capacity }\end{array}$ & $\begin{array}{l}\text { Operable } \\
\text { Capacity }\end{array}$ & $\begin{array}{l}\text { Ownership } \\
(\%)\end{array}$ \\
\hline ANPP & Government & Armenia & Nuclear & $815 \mathrm{MW}$ & $407 \mathrm{MW}$ & 100 \\
\hline Hrazdan TPP & Gazprom & Russia & Thermal & $810 \mathrm{MW}$ & $420 \mathrm{MW}$ & 100 \\
\hline Hrazdan-5 & Gazprom & Russia & Thermal & $440 \mathrm{MW}$ & $440 \mathrm{MW}$ & 100 \\
\hline Yerevan CCGT & Government & Armenia & Thermal & $242 \mathrm{MW}$ & $242 \mathrm{MW}$ & 100 \\
\hline $\begin{array}{l}\text { Yerevan Thermal } \\
\text { Power Plant } \\
\text { (YTPP) }\end{array}$ & Government & Armenia & Thermal & $550 \mathrm{MW}$ & $0 \mathrm{MW}$ & 100 \\
\hline $\begin{array}{l}\text { Sevan-Hrazdan } \\
\text { Cascade }\end{array}$ & Inter RAO-UES & Russia & Hydro & $560 \mathrm{MW}$ & $560 \mathrm{MW}$ & 100 \\
\hline Vorotan Cascade & Contour Global & USA & Hydro & $404 \mathrm{MW}$ & $404 \mathrm{MW}$ & 100 \\
\hline $\begin{array}{l}\text { Small Hydros } \\
(<30 \mathrm{MW})\end{array}$ & Various Owners & Various & Hydro & $267 \mathrm{MW}$ & $267 \mathrm{MW}$ & $\mathrm{n} / \mathrm{a}$ \\
\hline
\end{tabular}

Source: Bank team based on data from the Ministry of Energy and Natural Resources.

2.6. The sector closed 2014 with a financial deficit of AMD 47.4 billion $^{7}$ (1.0 percent of GDP) or 48.6 percent of total revenue of state-owned power companies. Although the revenues of the state-owned power companies rose in 2014 (to AMD 97 billion $^{8}$ ) due to tariff increases in YTPP, ANPP, and HVEN, the financial gap is not expected to close by 2019.9

\footnotetext{
${ }^{7}$ As measured by the cash flow from operating activities less cash flow from investing activities and debt service plus outstanding payables of YTPP against gas.

${ }^{8}$ Aggregate revenues of all state-owned entities from tariff-regulated activities.

${ }^{9}$ Including payables.
} 
Table 6. Aggregate Financing Gap of State-Owned Power Companies (million AMD)

\begin{tabular}{|l|r|r|r|r|r|r|}
\hline & $\mathbf{2 0 1 4}$ & $\mathbf{2 0 1 5 f}$ & $\mathbf{2 0 1 6 f}$ & $\mathbf{2 0 1 7 f}$ & $\mathbf{2 0 1 8 f}$ & $\mathbf{2 0 1 9 f}$ \\
\hline $\begin{array}{l}\text { Cash flows from operating } \\
\text { activities }^{\mathrm{a}}\end{array}$ & 8,492 & 5,253 & 5,996 & 3,656 & 4,654 & 10,293 \\
\hline $\begin{array}{l}\text { Cash flows from investing } \\
\text { activities }^{\mathrm{b}}\end{array}$ & $(3,712)$ & $(19,755)$ & $(40,522)$ & $(48,081)$ & $(37,996)$ & $(7,939)$ \\
\hline $\begin{array}{l}\text { Cash flows from financing } \\
\text { activities }^{\mathrm{c}}\end{array}$ & $(27,900)$ & $(7,785)$ & 20,836 & 27,924 & 16,306 & $(15,605)$ \\
\hline Financing Gap & $\mathbf{( 2 3 , 1 2 0})$ & $\mathbf{( 2 2 , 2 8 7 )}$ & $\mathbf{( 1 3 , 6 9 0 )}$ & $\mathbf{( 1 6 , 5 0 1})$ & $\mathbf{( 1 7 , 0 3 6 )}$ & $\mathbf{( 1 3 , 2 5 2}$ \\
\hline
\end{tabular}

Source: Bank team based on the financial statements of the state-owned power companies and the publicly available data from the Public Services Regulatory Commission.

Notes: $\mathrm{f}=$ forecast;

a: Net income + adjustments for depreciation + finance costs + changes in working capital;

b: Sale of Property, Plant, and Equipment (PPE) - Acquisition of PPE;

c: Loans and credits received - Loans and credits provided - repayments related to outstanding loans.

\section{Potential Liabilities for the State Budget}

2.7. As of August 1, 2015, the power sector had AMD 14.5 billion in short-term bank loans, which may become a liability for the public budget. The swelling debt service requirements are one of the main reasons behind the widening of the financial gap. The state-owned power companies have accumulated AMD 15 billion in expensive short-term debt through commercial loans (15 percent of their 2014 revenue) and AMD 24.3 billion in payables (25 percent of their 2014 revenue). The maturities for most of the loans are below 12 months with annual interest rates of 10.00-11.75 percent. These commercial loans cost the sector AMD 1.5 billion in interest per year (Table 7). YTPP's AMD 24.3 billion debt to Gazprom for natural gas is the single largest outstanding payable. This payable was accrued due to a severe cash shortage at YTPP in 2012-2014 resulting from lending (to the Nairit and Vanadzor chemical plants) and expenses for non-core business purposes. The remaining payables are primarily owed by the ANPP and HVEN for purchased equipment and other materials.

Table 7. Largest Outstanding Commercial Debts of State-Owned Companies

\begin{tabular}{|l|l|l|l|}
\hline & $\begin{array}{l}\text { Total principal } \\
\text { outstanding (billion } \\
\text { AMD) }\end{array}$ & $\begin{array}{l}\text { Annual interest } \\
\text { rate (\%) }\end{array}$ & $\begin{array}{l}\text { Estimated annual } \\
\text { interest expense (billion } \\
\text { AMD) }\end{array}$ \\
\hline YTPP & 6.81 & $9.00-11.5$ & 0.70 \\
\hline ANPP & 7.68 & $9.00-11.75$ & 0.80 \\
\hline Total & $\mathbf{1 4 . 4 9}$ & & $\mathbf{1 . 5 0}$ \\
\hline
\end{tabular}

Source: Bank team based on the financial statements of the state-owned power companies and data from MENR. 
2.8. It is worrisome that, going forward, YTPP and ANPP will not be able to service their expensive commercial loans. ${ }^{10}$ Available earnings to service the debt, determined as the revenues of the companies' net of required operating and maintenance (O\&M) costs and taxes, are not expected to return to sustainable levels. In 2015, YTPP is estimated to have serviced only 36 percent of its loans and ANPP only 35 percent, with a slight improvement in the coming years provided that ENA resumes timely payments against electricity purchases (following an August 2015 tariff increase) and YTPP and ANPP do not resort to new expensive short-term commercial loans to finance working capital needs. However, starting in 2017, the increasing cost of rolling over the existing commercial debt will manifest itself in the reduction of debt coverage ratio.

Table 8. Ability to Service Loans (\%)

\begin{tabular}{|l|l|l|l|l|l|l|}
\hline & $\mathbf{2 0 1 4}$ & 2015est. & $\mathbf{2 0 1 6 f}$ & $\mathbf{2 0 1 7 f}$ & $\mathbf{2 0 1 8 f}$ & 2019f \\
\hline YTPP & 63 & 36 & 36 & 32 & 28 & 24 \\
\hline ANPP & 9 & 35 & 55 & 56 & 50 & 43 \\
\hline
\end{tabular}

Source: Bank team based on the financial statements of the state-owned power companies and data from MENR.

Note: $\mathrm{f}=$ forecast.

2.9. The accumulation of receivables at state-owned companies also contributed to the financial gap. The state-owned power companies also accumulated significant receivables from privately-owned ENA, which is struggling to make timely payments for electricity purchased. ENA's financial distress is due to an inadequate mechanism for compensating losses incurred that suffers from a mismatch between the forecast and actual electricity supply mix. By August 2015, the four state-owned companies had accrued a total of AMD 22.4 billion in receivables from ENA.

Table 9. ENA's Payments and Debt to State-Owned Power Companies (\%)

\begin{tabular}{|l|c|c|c|c|}
\hline & $\mathbf{2 0 1 2}$ & $\mathbf{2 0 1 3}$ & $\mathbf{2 0 1 4}$ & $\begin{array}{c}\text { ENA's debts in } \\
\text { March 2015 (billion } \\
\text { AMD) }\end{array}$ \\
\hline YTPP & 101 & 88 & 67 & 12.2 \\
\hline ANPP & 101 & 100 & 93 & 7.2 \\
\hline HVEN & 110 & 90 & 82 & 3.0 \\
\hline
\end{tabular}

Source: Bank team based on the financial statements of the state-owned power companies and data from MENR.

2.10. Electricity bill collection rates from consumers have no impact on ENA's debts to large generating companies. Overall, the collection rates remain robust at 99 percent (in 2014).

${ }^{10}$ All conclusions and recommendations of this chapter are drawn by the World Bank's energy team working on Armenia based on the on-going policy dialogue with the Armenian authorities. 
The reduction from 100 percent is due to the deceleration of economic activity and the inability of some industrial consumers and the irrigation sector to pay their bills in a timely manner.

2.11. The recent GoA decision regarding end-user electricity tariffs will likely cost the state budget at least AMD 17 billion. The GoA has recently decided to subsidize the cost of electricity to customers as a response to public discontent regarding a 15 percent end-user tariff increase effective as of August 1, 2015. Specifically, ENA will continue billing the customers at old tariffs and the government committed to reimburse the revenue shortfall (equal to the difference between the old and new tariffs - AMD 6/kWh) until the completion of the audit of ENA, after which the targeted Family Benefits Program will adjust to allow compensation for vulnerable households only.

\section{B. Reasons Behind the Deterioration of the Financial Condition of the State Power Companies}

2.12. As explained in the previous section, Armenia's growing financial gap in the energy sector can be largely attributed to three key areas affecting state-owned enterprises. This expanding financing gap is due to: (a) incurring expenses and lending/borrowing for non-core business activities; (b) non-payments by ENA; and (c) below-cost recovery tariffs.

2.13. Assessment of non-core business related borrowing, lending, and expenses shows close linkages with loss-making chemical companies. The government used the funds of the state-owned power companies to finance some recurrent expenses, basic O\&M, and salaries of the Nairit and Vanadzor chemical plants. The GoA also mandated the state-owned companies to borrow funds and on-lend to these chemical plants. The state-owned companies were able to make such lending by reducing their spending on required O\&M and repairs and taking short-term, high-interest loans from commercial banks. As of August 1, 2015, the total outstanding debt of the Nairit and Vanadzor chemical plants to Vorotan and YTPP was AMD 28 billion (0.6 percent of GDP). Moreover, YTPP took a \$2.6 million loan to lend to the Nairit chemical plant. The Nairit chemical plant also owes YTPP AMD 6.6 billion for supplied energy (Table 10). 
Table 10: Outstanding Liabilities (in million AMD)

\begin{tabular}{|c|c|c|c|c|c|c|}
\hline $\mathbf{N}$ & Lender & 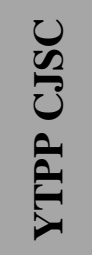 & 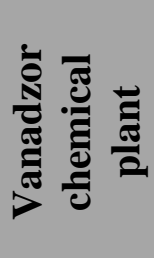 & 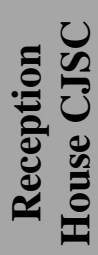 & 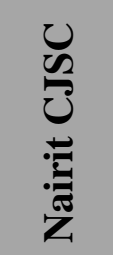 & 疍 \\
\hline 1 & ANPP & 1,802 & & & & 1,802 \\
\hline 2 & YTPP & & 6,286 & 26 & 17,576 & 23,888 \\
\hline 3 & HVEN & 100 & & & & 100 \\
\hline & Total & 1,902 & 6,286 & 26 & 17,576 & 25,790 \\
\hline
\end{tabular}

Source: Bank team based on data from MENR.

2.14. In addition, the power sector entities (primarily Vorotan) incurred several large expenses unrelated to their core business activities. Specifically:

a) During 2010-2011, Vorotan and YTPP financed AMD 1.6 billion worth of capital renovation and maintenance of the government's reception and ceremony house because the Ministry of Energy and Natural Resources was mandated to take on the management and maintenance of this asset.

b) Gas subsidies to the poor in the amount of AMD 1.1 billion for gas consumed in 20122013. The subsidy was paid in 2014. Based on data available, the state-owned power sector companies have not incurred any expense to cover the cost of the subsidy since then. Besides, the state-owned power companies cannot afford to pay the subsidy given a substantial cash deficit in the sector.

c) Over AMD 1 billion from Vorotan's operating cash flows and profits was used to finance some other infrastructure investment (e.g. the construction of a road section).

2.15. The state-owned power companies are not likely to recover the receivables and loans/credits provided to chemical plants. Specifically, YTPP is not likely to recover the receivables for steam and the loans provided even if the GoA proceeds with the liquidation of the Nairit plant. The fair value of Nairit's assets is quite likely substantially below the book value given the obsolescence and severe dilapidation of the plant's infrastructure. Moreover, YTPP's claims have lower standing in terms of seniority. The same is relevant for the Vanadzor chemical plant. If the receivables and loans provided by the state-owned power companies are written off, this would mean AMD 33 billion in losses for the state-owned power companies, which may lead to negative equity.

2.16. An inadequate mechanism for exogenous compensation has caused ENA's losses. ENA is the single buyer in the power market and its tariff is the difference between the end-user electricity tariff (one-part tariff) and the capacity charge of generating plants (fixed charge that most generators receive irrespective of the generation volume to recover their fixed costs), the weighted average cost of the energy charge of generating plants ( $\mathrm{kWh}$ based charge), the transmission charge, and the service fees of the power system operator and the settlement center. Thus, if the actual consumption is lower than the volume planned under the tariffs, or the share of 
expensive generation plants is larger than that planned under the tariffs, ENA incurs a loss. As per the current regulatory approach (specified in the ENA's license), that loss is recovered in equal installments in three years and it does not include compensation for interest costs ENA incurs to finance the working capital until the losses are compensated. Due to substantial deviation of the planned vs. the actual generation mix in 2012-2014, the Bank team estimates ${ }^{11}$ that ENA incurred a cumulative loss of around AMD 27 billion despite a 40 percent increase of average end-user tariffs in the 2012-2014 period. ENA had to rely on short-term commercial loans to finance the shortage of working capital resulting from this loss. The losses were caused by a larger-than-planned share of highest-cost electricity that ENA had to purchase from Hrazdan TPP. This occurred because generation by the large hydro cascades in 2013-2014 was substantially lower than planned due to low precipitation; and YTPP was selling to the domestic market a smaller-than-planned share of generation from its low-cost combined cycle gas turbine unit given its commitments to supply electricity to Iran under the electricity-for-gas swap deal.

Table 11. O\&M Costs, Depreciation Expenses, and Return on Assets (million AMD ${ }^{12}$ )

\begin{tabular}{|l|r|r|r|r|r|r|r|}
\hline YTPP & $\mathbf{2 0 0 8}$ & $\mathbf{2 0 0 9}$ & $\mathbf{2 0 1 0}$ & $\mathbf{2 0 1 1}$ & $\mathbf{2 0 1 2}$ & $\mathbf{2 0 1 3}$ & $\mathbf{2 0 1 4}$ \\
\hline O\&M and repairs & $\mathrm{n} / \mathrm{a}$ & $\mathrm{n} / \mathrm{a}$ & $\mathrm{n} / \mathrm{a}$ & 1,028 & 1,028 & 1,028 & 5,247 \\
\hline Depreciation & $\mathrm{n} / \mathrm{a}$ & $\mathrm{n} / \mathrm{a}$ & $\mathrm{n} / \mathrm{a}$ & 0 & 0 & 0 & 0 \\
\hline Return on assets & $\mathrm{n} / \mathrm{a}$ & $\mathrm{n} / \mathrm{a}$ & $\mathrm{n} / \mathrm{a}$ & 0 & 0 & 0 & 0 \\
\hline HVEN & $\mathbf{2 0 0 8}$ & $\mathbf{2 0 0 9}$ & $\mathbf{2 0 1 0}$ & $\mathbf{2 0 1 1}$ & $\mathbf{2 0 1 2}$ & $\mathbf{2 0 1 3}$ & $\mathbf{2 0 1 4}$ \\
\hline O\&M and repairs & 570 & 570 & 570 & 570 & 570 & 570 & 570 \\
\hline Depreciation & 1983 & 1983 & 520 & 1983 & 0 & 1983 & 2100 \\
\hline Return on assets & 747 & 663 & 0 & 535 & 0 & 366 & 209 \\
\hline
\end{tabular}

Source: Bank team based on data from MENR.

2.17. Currently, tariffs for state-owned power companies are below cost-recovery levels. The power sector tariffs in 2008-2014 were below cost-recovery levels for the following reasons: (a) the non-fuel O\&M costs included in the tariff were declining in real terms given constant nominal allocation and cumulative 30 percent inflation during the same period; and (b) several of the state-owned companies were not receiving justified depreciation expenses and/or the required return on assets (Table 11). The Ministry of Energy and Industry, as the owner of those companies on behalf of the government, was requesting the PSRC to lower/waive depreciation and return on assets to reduce the pressure on end-user electricity tariffs given the increasing costs of thermal generation.

\footnotetext{
11 Based on publicly available data from PSRC.

${ }^{12}$ Was commissioned end of 2010.
} 


\section{Energy Sector Subsidies}

2.18. The gas subsidy for the poor is the only explicit subsidy in the energy sector. The gas subsidy was introduced in 2012 following a one-time 30 percent increase of end-user gas tariffs in the same year. All poor families involved in the Poverty Family Benefit Program are eligible for this life-line gas subsidy. The tariff for poor families was set at AMD $100 / \mathrm{m}^{3}$ for the first $300 \mathrm{~m}^{3}$ of gas consumed, compared to the regular tariff of AMD $156 / \mathrm{m}^{3}$. The threshold was increased to 450 $\mathrm{m}^{3}$ in 2013. Rather than relying on state or local budgets, the state-owned power companies were mandated to finance the subsidy. It cost the power sector AMD 1.1 billion in 2012-2013. However, continued financing of the subsidy was not possible given the financial distress of the state-owned power companies and it has been discontinued since 2014.

\section{Fiscal Cost of New Power Sector Investment}

2.19. The power transmission sector will require around $\mathbf{\$ 2 0 0}$ million in new investment by 2019. Such investment is required for: (a) rehabilitation of a number of substations and power transmission lines to ensure reliable domestic supply of electricity; and (b) strengthening of the regional interconnections with neighboring countries (e.g. a new transmission line, substation, and back-to-back converter project to increase the transmission capacity with Georgia). This investment will most likely be financed through sovereign borrowing. However, the sovereign borrowing for power sector investment is not a direct burden on the state budget because debt service costs for all of the projects, financed by the IFIs and other development partners, are included in the tariffs of respective power companies and the repayment burden is passed on to end-users of electricity.

2.20. The power generation sector will require around $\$ 750$ million in investment by 2019 , which should predominantly be financed with private capital. This investment is required to meet the forecast electricity demand in the country. The largest investments include the $500 \mathrm{MW}$ combined cycle gas turbine (CCGT) plant, which has a capital cost of around $\$ 550$ million, followed by utility-scale solar and wind projects. The planned investment is estimated to: (a) increase the external public debt by $\$ 56$ million, which includes the $\$ 26$ million of very concessional loans for a solar PV project from Scaling-Up Renewable Energy (SREP) ${ }^{13}$ under the Climate Investment Fund and sovereign borrowing from other IFIs (e.g. the World Bank and ADB) as reflected in the SREP Investment Plan for Armenia (June 2014); and (b) increase the contingent liabilities of the government by up to $\$ 180$ million. Specifically, development of the CCGT plant will require an IFI guarantee (e.g. IBRD) of up to $\$ 180$ million to attract commercial lenders to the project in order to improve the terms of the debt and reach financial close (Table 12).

\footnotetext{
${ }^{13}$ Similar to IDA terms.
} 
Table 12. Pipeline of Main Power Generation Projects to Meet Domestic Demand by 2019

\begin{tabular}{|l|c|c|c|c|c|}
\hline Project & $\begin{array}{c}\text { Size } \\
\text { (MW) }\end{array}$ & $\begin{array}{c}\text { Overnight } \\
\text { Capital Cost } \\
\text { (million \$) }\end{array}$ & $\begin{array}{c}\text { Financing } \\
\text { Mode }\end{array}$ & $\begin{array}{c}\text { Expected } \\
\text { Commissioning } \\
\text { Date }\end{array}$ & $\begin{array}{c}\text { Impact on } \\
\text { Government's } \\
\text { Balance Sheet }\end{array}$ \\
\hline New CCGT & 500 & 550 & PPP & 2019 & $\begin{array}{c}\$ 180 \text { million } \\
\text { guarantee }\end{array}$ \\
\hline Wind power & 50 & 100 & $\begin{array}{c}\text { Purely } \\
\text { private }\end{array}$ & 2018 & - \\
\hline $\begin{array}{l}\text { Utility-scale } \\
\text { solar PV }\end{array}$ & 50 & 100 & PPP & 2017 & $\begin{array}{c}\text { \$26 million } \\
\text { concessional } \\
\text { credit from } \\
\text { SREP and \$30 } \\
\text { million IFI loan }\end{array}$ \\
\hline Total & $\mathbf{7 7 1}$ & $\mathbf{1 1 0 4}$ & & & \\
\hline
\end{tabular}

Source: Bank team estimates.

2.21. The above investments into new generation capacity are required to ensure adequate electricity supply to meet the long-term demand. Without this investment (especially the new CCGT plant), the power system will not be able to meet the electricity demand in full and at all times. This will impose significant economic and social costs on the country.

\section{E. Poverty Impact of Tariff Increases}

2.22. With increasing electricity and gas tariffs, the share of the population living below the poverty line is growing. The 2013 electricity and gas tariff increases were estimated to have increased the share of poor households by 3 percentage points. The number of poor households is expected to have further increased following a 10 percent electricity tariff increase in 2014 and an additional increase in June 2015. For the average household, the energy expenditure as a share of total expenditures was estimated to reach 10 percent in 2015, a level considered to be "energy poverty." Again, the poor would be the hardest hit, with the energy share of the poorest quintile reaching 16 percent without the gas subsidy. The gas subsidy, which is quite progressive, supplies 50 percent of the transfer to the poorest quintile. However, only 25 percent of the poorest quintile and 18 percent of the poor, as per the 2013 baseline, are covered by this subsidy scheme. 
Figure 22. An Increase in Energy Expenditure as a Share of Total Household Expenditure would Affect Poorer Households More than Richer Households

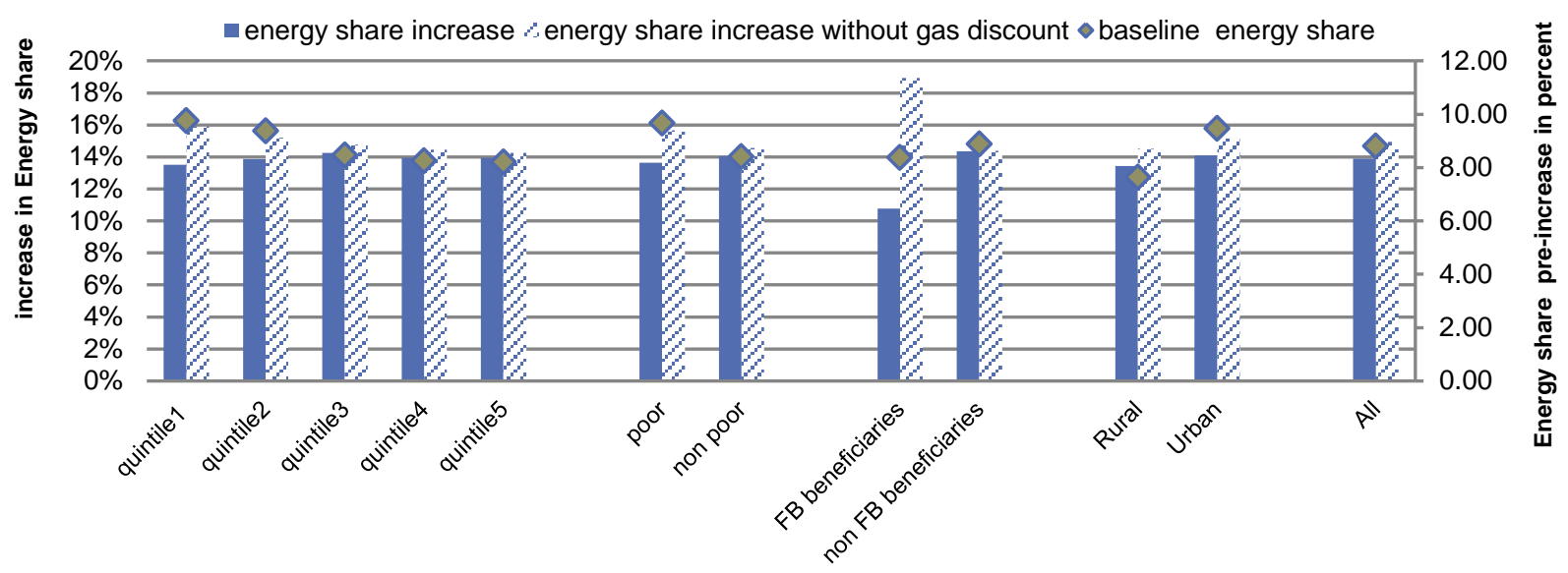

Source: Bank team based on ILCS 2012 data.

\section{F. Recommendations}

\subsection{To fix the power sector's current financial distress, a set of measures need to be} undertaken immediately:

1) Prohibit expenses, borrowing, and lending that are not related to the core business of state-owned power companies. The government, as the owner of the state-owned companies, could issue a decree prohibiting those companies from: (a) borrowing for non-core business activities; (b) lending to each other or other companies; and (c) incurring expenses not related to their core business, including financing of gas subsidies for the poor.

2) Consider developing and implementing a liquidation plan for the Nairit chemical plant and start a legal process to collect the Vanadzor chemical plant debts. The technical and economic viability analysis of the Nairit chemical plant suggests that it cannot be a competitive supplier of poly-chloroprene rubber (PCR) given the high feedstock and energy costs. Thus, if the GoA does not address the issue, it will remain a major drain on the financial resources of the power sector companies. The privately-owned Vanadzor chemical plant accumulated large debts to the state power companies, which should be collected through a legal process. The government should also make a decision on receivables from and loans provided to the chemical plants with a total amount of AMD 33 billion. If written off, given the very low likelihood of recovery, it will create an equivalent loss and lead to negative equity if the government does not increase the capital of the affected state-owned power companies. 
3) Allow for recovery of ENA's AMD 30 billion in losses, which accumulated for external reasons. To avoid insolvency of the company, the PSRC should allow for the recovery of ENA's accumulated losses (including interest costs), which resulted from the difference between the forecast and actual generation mix. The recovery of the losses could be done through a combination of: (a) gradual end-user tariff increases and (b) the refinancing of expensive ENA debts with longer term and less expensive debts. ENA should consider developing a financial recovery plan in coordination with the GoA and the PSRC in order to secure longer maturity and lower interest rate financing with potential financiers, such as the private arms of the IFIs. The Bank team estimates that the recovery of ENA's accumulated losses will require a 14 percent (ADM6/kWh) increase of the end-user tariff. Such an increase through a one-time adjustment would likely have a tangible adverse impact on poverty.

4) Adjust the regulatory/tariff methodology to avoid repetition of ENA's loss build-up due to a mismatch between the forecast and the actual power generation mix. The two recommended options for addressing the underlying regulatory shortcoming include:

a. Adopt a two-part end-user tariff. The PSRC could consider adopting a two-part end-user electricity tariff with a fixed service fee to be paid irrespective of consumption volume to compensate for the fixed costs of power companies, and a variable energy charge to be paid per $\mathrm{kWh}$ of consumption and determined as the weighted average energy charge of the generation (e.g. ex-post for each month) plus the charges for transmission and distribution. Such an approach would eliminate the power demand and generation mix risks for ENA and preclude future build-up of losses and negotiations/disputes on loss recovery.

b. Allow for recovery of losses + working interest. The PSRC should consistently apply the existing methodology for compensation of losses given the mismatch and ensure that ENA recovers the accumulated loss plus the working interest.

5) Refinance the commercial loans of state-owned companies and redeem the commercial payables to avoid the default of troubled companies. This can be done as follows:

a. Refinance commercial debts. The government, as the owner, could seek refinancing of the outstanding AMD 15 billion in short-term commercial loans for YTPP and ANPP — which cost the sector AMD 1.4 billion annually in interest expenses - with more concessional resources.

b. Negotiate with Gazprom a schedule for repayment of the YTPP payable. YTPP should negotiate with Gazprom the restructuring of the AMD 24 billion payable for gas and agree on a four-year repayment schedule. Two options to finance the repayment of this payable are listed below.

6) Introduce adjustments in $O \& M$ costs. The PSRC needs to abandon the practice of keeping the O\&M costs allowed in tariffs unchanged. The PSRC could consider a one-time adjustment of the maintenance costs through benchmarking of the allowed depreciation against the age of the assets and allowing inflation adjustment of $O \& M$ costs thereafter. 
7) Structure the new generation projects as PPPs to involve private capital in the development of the required generation capacity. This will substantially reduce the fiscal impacts of new investment. Specifically, the GoA should consider building new mid-size renewable energy projects as PPPs. The government could still selectively provide limited concessional resources to those projects with the objective of reducing the electricity tariffs of the projects given the electricity affordability considerations.

8) Ensure adequate protection of the poor consumers against energy tariff increases. The Bank team recommends that the GoA consider three options for mitigating the impact of increasing energy tariffs on the poor. Option 1: Compensation distributed through targeted lifeline tariffs would have the most limited impact in terms of coverage of the poor (16 percent), and the lowest level of poverty reduction (around 0.5 and 0.7 percentage points). Option 2: Giving a cash-based benefit to Family Benefits Program (FBP) beneficiaries. Or Option 3: Giving a cash-based benefit to all registered households with a score above zero. Options 2 and 3 would allow reaching between 21 and 25 percent of the poor, including households that are not directly consuming gas but are facing indirectly higher prices (for instance, higher firewood costs). Ultimately, however, Options 1, 2, and 3 are tantamount to a simple top-up of the existing FBP; this would not address existing biases in targeting and coverage, with a cost of about 0.05 percent of 2012 GDP. Moreover, the government could also further improve the FBP targeting formula to increase its targeting accuracy, and also reform it in order to enable the inclusion of a larger share of poor households than it does at present (see the World Bank note: "Protecting Vulnerable Households from Rising Energy Tariffs: Policy Options for Armenia," which was distributed to the GoA in early 2015). 


\section{Chapter 3: An Assessment of Explicit Public Subsidies}

\section{A. Overview}

3.1. Fiscal sustainability, equity, and efficiency of public spending are the main considerations when analyzing public subsidies. Subsidies, in particular untargeted ones, are generally not efficient in supporting the poor. They impose a heavier burden on public finances than more targeted social protection tools and they generate welfare costs by distorting relative prices in the economy, which in turn fosters overconsumption. Replacing subsidies with appropriate social safety net instruments could lead to stronger social protection measures and, at the same time, generate fiscal savings. Concerns over efficiency might also be raised, as subsidies can potentially crowd out the private sector and create monopolies at the expense of consumers who bear a higher cost.

3.2. This chapter reviews the current status of explicit public subsidies in Armenia. It responds to the GoA's request to provide an updated assessment of the sustainability of budget subsidies and whether there is a scope for rationalization given the current challenge of fiscal consolidation. It (a) clarifies the nature and classification of explicit public subsidies; (b) analyzes their equity and efficiency with regard to their explicit or implicit objectives; and (c) makes recommendations with regard to the prior two objectives for fiscal sustainability.

Figure 23. Composition of Subsidies, 2014

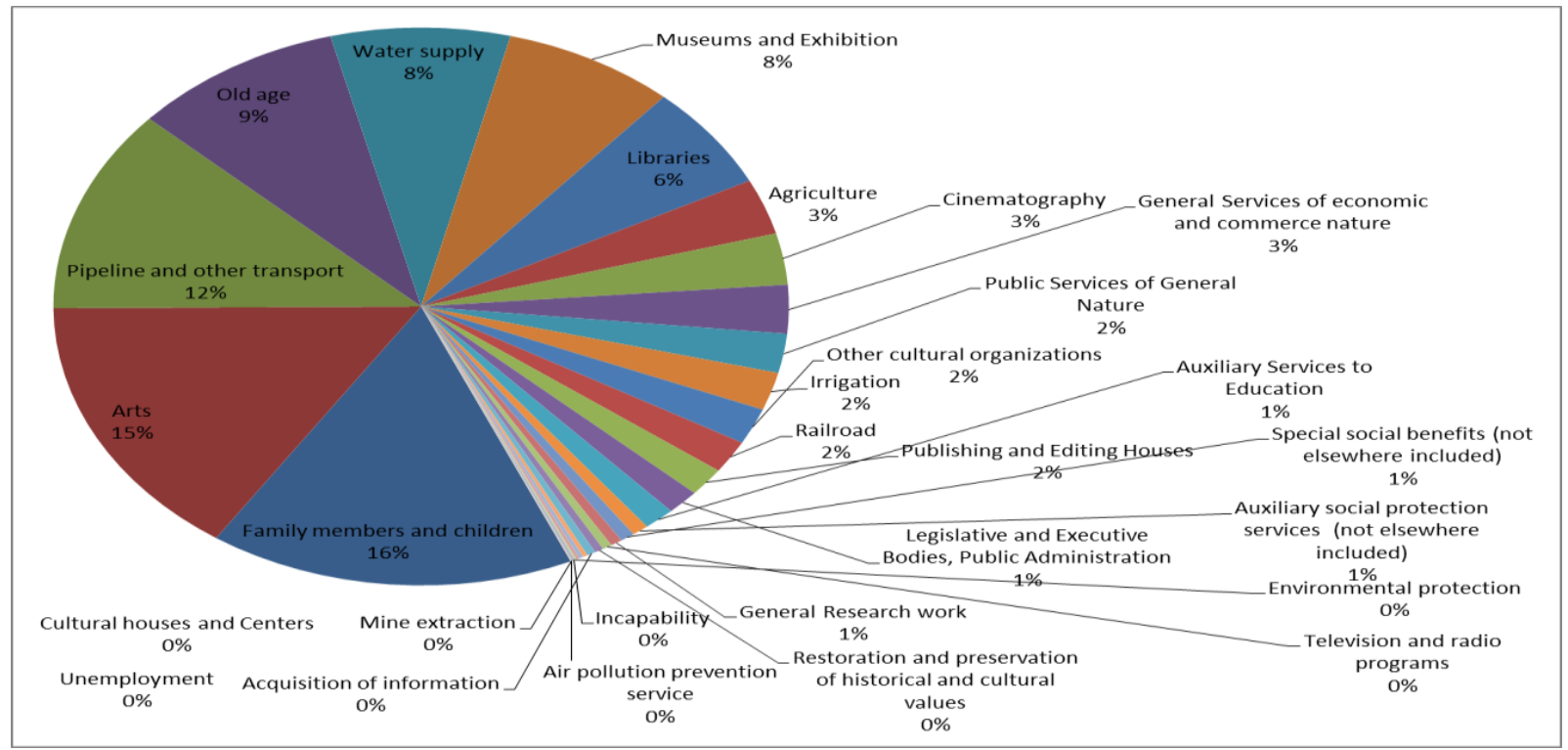

Source: Ministry of Finance of Armenia. 
3.3. Explicit budget subsidies are not large in Armenia, but their nature varies greatly and their number is relatively high. They account for about 0.5 percent of GDP, about 1.7-1.8 percent of total public spending, and 2.3 percent of non-interest recurrent expenditures. Furthermore, over the last 10 years, subsidies have consistently declined as a share of total expenditures (from 3.6 percent in 2006 to 1.7 percent in 2014). That said, given the very limited fiscal space of the budget in Armenia, any possibilities of expenditure rationalization could be useful.

3.4. The number of existing explicit subsidies is relatively high for their respective amount. There are 32 different categories of subsidies, with a median subsidy of 0.03 percent of total public expenditures. With the exception of 2008 when massive subsidies were provided to the mineral oils and natural gas sectors, water/irrigation/transport and agriculture are the main beneficiary sectors (about 25 percent of total subsidies). As a result, it is likely that the administration costs associated with these subsidies are high relative to their benefits. Some areas where administration costs are incurred include: (a) ex-ante, determining the optimal subsidy amount in an environment of asymmetric information; (b) establishing the right delivery mechanism; and (c) monitoring and evaluating whether the government is getting value for its money when allocating subsidies. Taking a hard look at the performance of the various subsidy schemes is critical to assessing whether they are the best instrument to deliver results in a cost-effective way.

3.5. The composition of subsidies varies widely and they can be categorized as "traditional," i.e. in line with the IMF Government Financial Statistics (GFS) definition, or "peculiar" or inconsistent with international practices regarding budget expenditure classifications. A preliminary review of the various items classified as subsidies suggests that only one-third should be categorized as subsidies. These are mainly directed to: pipeline and other transports: subsidized metro tariffs (12 percent of total subsidies); water supply: subsidized water tariffs ( 8 percent); agriculture: subsidized bank loans ( 3 percent); irrigation: subsidized irrigation services ( 2 percent); railroad: subsidies to the railroad company to cover current losses ( 2 percent).

3.6. According to the GFS nomenclature, a number of existing public expenditure items currently classified as subsidies are actually grants or transfers. The GFS defines subsidies as: "current unrequited transfers that government units make to enterprises on the basis of the level of their production activities or the quantities or values of the goods or services they produce, sell, export, or import." When a subsidy finances the full operating and capital cost of running the activity, the scheme should be reclassified as a transfer or grant. This could be the case of the social benefits subsidy scheme, which comprises one-third of total subsidies. Family member and children subsidies, which account for 16 percent of total subsidies, should probably be treated as transfers (they consist of care services for children). The same applies to old age subsidies (9 percent of total subsidies), special social benefits, and unemployment. This could also apply to certain subsidies for culture, a category that lacks alternative sources of funding (Box 2). 
Box 2: Classification in Government Finance Statistics: Subsidies, Grants, and Transfers

Distinguishing between subsidies, social benefits, grants, and current transfers not elsewhere classified can be difficult in practice, especially with limited information. Small differences in the way these payments are made, or the legal basis on which they are paid, can affect the classification. The nature of the recipient can also affect the classification; for example, subsidies can generally not be received by households or by non-profit institutions serving households (NPISH).

Definitions for each of these different kinds of expenditures are provided in the IMF Government Finance Statistics Manual 2014 (GFSM 2014), in Chapter 6, and in particular in the paragraphs on subsidies §6.84-6.91, grants §6.91-6.95, social benefits §6.96-6.98, and other transfers not elsewhere classified $\$ 6.122-6.124$.

The following three examples of payments do not qualify as subsidies, but rather as grants:

- Subsidies to culture (funding for theaters, libraries, performances, etc.): Treatment of these payments will depend on the classification of the libraries, theatres, etc. If these entities receive most of their funding from the government and they are in the public sector, they will probably be considered state non-commercial organizations, like the secondary schools and childcare providers below. This would make them government units, and the payments to them would probably be classified as grants. If these units were private sector units but still received most of their funding from the government, they would probably be classified as NPISH and payments would likely be transfers not elsewhere classified (by definition, grants can only be received by government units). If these entities are private sector units that mainly cover their costs through sales to consumers, such that the government funding represents only a small portion of their funding, these units would probably be classified as nonfinancial corporations and the payments could qualify as subsidies.

- Subsidies to childcare institutions and old age: Payments here are most likely grants, from one government unit to another. However, if these childcare institutions are free to only some low-income households and other households pay (and the state-owned institutions compete with the private sector ones), then it is possible that the institutions themselves could be classified as public nonfinancial corporations outside the general government sector. In this case, the payments may be a form of social benefit, though this is unlikely.

- Government outsources all secondary education services to State (non-government) Non-Commercial Organizations: As for childcare institutions, these expenditure items should be classified as grants. Secondary education is free in state-owned schools for everyone in Armenia, meaning that the schools are almost entirely, if not entirely, funded by the government. 


\section{B. Assessing Subsidies: Nuts and Bolts}

3.7. Subsidies might be seen as an investment for the government to facilitate the delivery of public services at an affordable price. It is then critical for the government to set clear objectives for any subsidy scheme, while at the same time designing a monitoring and evaluation mechanism to measure whether subsidies support ex-post the achievement of the ex-ante objective. Should the subsidy not meet its pre-defined objective, it is important to have a governance mechanism in place to enforce any course correction.

\section{Assessing Subsidy Performance Based on Ex-Ante Objectives}

3.8. Subsidy efficiency and/or equity should be assessed by looking at the extent to which their stated objectives are achieved. Too often, the focus of subsidies is input-driven as opposed to focusing on end-outputs and outcomes. In addition, the impact of various subsidy schemes is best analyzed when grouped by end-beneficiaries. The appropriate targeting of subsidy programs needs to be formulated and implemented with a good understanding of the following questions:

- Who are the intended beneficiaries of the subsidy and how best can those recipients be targeted?

- Is the principal objective of the subsidy program increased efficiency-implying that they should be targeted where they bring the biggest increase in efficiency —or is the objective one of equity where the government seeks to improve the welfare of beneficiaries? Analyzing efficiency means looking at productivity indicators for a given amount of subsidy, while analyzing equity means looking at the distribution of subsidies vis-à-vis specified equity criteria (often to what extent vulnerable groups benefit from the subsidy, through incidence analysis).

- What indicators should be used to assess performance toward the objective?

- Is a subsidy the best instrument to reach the stated objective? Is there any alternative scheme that would be more cost-efficient? While subsidies are often less costly to implement, targeted interventions or schemes going directly to beneficiaries are often more efficient.

- What monitoring and evaluation mechanism will be linking the subsidy with expected outputs and outcomes? What enforcement mechanism will be applied?

\section{Strengthening Monitoring and Evaluation and (Across-the-Board) Public Oversight}




\section{Functions}

3.9. While the financial reporting of subsidies appears to be well-established across the board, the regular monitoring and assessment of their performance is not in place. Ex-post monitoring and evaluation of subsidies as stated above is critical in order to assess their adequacy. This should be done at the level of the Ministry (monitoring department), of the government's internal audit, and outside the government with external audit functions through financial or compliance-based and performance assessments. Armenia's Public Expenditure and Financial Accountability (PEFA) 2014 assessment notes that monitoring and compliance audits of the government's financial statement, as well as performance audits, still need to be significantly strengthened. A particular concern of the Supreme Chamber is that subsidies are not subject to the same scrutiny by the Chamber and the National Assembly as the procurement of goods and services. Little information is provided to enable a meaningful assessment of compliance and performance. To address this gap, annual budget proposals could include a discussion of subsidies and their associated modalities of allocation and assessment of performance to enhance the transparency of the budget.

3.10. In addition, Armenia's various "State-Non-Commercial-Organizations" (SNCOs) are important recipients of subsidies. However, these extra-budgetary entities are not regularly audited and subject to less scrutiny than budget entities (that include for example water user associations, childcare institutions, old age homes, cultural institutions, etc.). Armenia's 2014 PEFA notes the possible risks posed to the budget by the extra-budgetary operations (EBOs) of SNCOs, which prepare periodic revenue and expenditure reports and financial statements and submit them to their Authorized Bodies and the Ministry of Finance. SNCOs are not, however, legally required to have their accounts audited. The government's monitoring of the financial situation of these EBOs is not a sufficient substitute for the auditing of their accounts by impartial auditors.

\section{Phasing Out Subsidies}

3.11. Ultimately, prices and tariffs should signal the true value of the service or good provided based on the cost-recovery of operations ad minima. In order to allow the market to reveal the true scarcity of goods and services, where appropriate, subsidies should be phased out on the basis of beneficiaries' affordability and providers' operational cost-recovery. This is needed not just to avoid wasting scarce resources and to more efficiently allocate them, but also to avoid market distortions created by an artificially low price of subsidized goods or services. Where financial support is still deemed warranted, it is best to replace subsidies with: (a) where equity is the objective, beneficiary-based targeting schemes, which could be more equitable based on pre-identified indicators; or (b) where efficiency is the objective, schemes based on performance, which could be more efficient in influencing incentives. Annex 2 provides a menu of options and steps for tariff reform and subsidies.

\section{Built-In Incentives to Improve Equity and Performance at the Provider Level}


3.12. In some instances, the political economy cost of reform might be too high for a given sector and a given moment in time to remove subsidies, or where the public-good nature of the service delivery is clear (e.g. presence of externalities). Where possible, performance-based contracts should be encouraged within public sector agencies or between the public sector and non-public organizations to incentivize better performance through regulated management autonomy of externalities (e.g. retained earnings, human resources, and essential services). Under a clear governance contract, partnering with the private sector for the delivery of these subsidized goods and services may also increase efficiency.

\section{An Analysis of Subsidies in Selected Sectors}

\section{Railway (Brief Assessment of the Armenian Railways Concession)}

3.13. After the collapse of the Soviet Union, the Armenian Railway's assets and operations were found to be unsustainable and the need for restructuring was evident. Underinvestment over decades had led to huge investment needs, including replacement of much of its rolling stock, continuing investment needs to maintain its main line between Yerevan and the Georgian border, significant infrastructure investment to renew its overhead power systems and several very old steel bridges, among many others. Existing passenger services also required the maintenance and renewal of a number of passenger stations and other facilities.

3.14. To finance critical investment needs, the GoA entered into a concession agreement in 2008 with the South Caucasus Railway (SCR), a subsidiary under guarantee of Russian Railways, to transfer operating rights of railway assets. It was felt the time that a concession was the solution to restructure the railway service while remaining in operation, since the government did not have the fiscal space to meet these critical needs. The railway concession entered into effect just as the global recession took hold. The prospects for traffic development were limited, unless progress with border openings could be achieved. Furthermore, the SCR had been facing increasing competition from truck transport.

3.15. The term of the contract was 30 years with an option to extend to 40 years by mutual consent. Bearing all the risks except force majeure, the concessionaire was obliged to operate freight and passenger services, maintain assets, and improve their condition. The concessionaire also committed to invest in infrastructure approximately $\$ 200$ million in the first five years and $\$ 400$ million over 30 years. In addition, the concessionaire was responsible for previously incurred debt and accounts payable. CPCS Transcom, a well-recognized firm with substantial rail concession experience, acted as transaction advisor in the finalizing and signing of the original contract, which largely conformed to good practice. The concession agreement stipulates that "the Concessionaire shall coordinate with the Concessor the minimum annual passenger traffic and directions. The Concessor (Ministry of Transport) will subsidize/partly compensate the annual loss incurred by the Concessionaire as regards the agreed volume and directions of passenger 
transportation, where the Concessionaire furnishes statement of accounts for such losses confirmed by an independent auditor." The agreed amount of subsidy is 25 percent of the amount of loss from passenger transportation estimated up to 2016 and 30 percent henceforth. It is also agreed that the annual amount of subsidy provision should be capped to the annual concession fee paid by the concessionaire to the Ministry of Transport.

\subsection{However, several shortcomings were observed at the time, including: ${ }^{14}$}

- Lack of clarity in overseeing the investment commitments to channel them into required areas and prevent gold plating;

- Weakness on investment and operations plans, currently consisting only of a description of the planned investments but not of the operations; no standards for improvement or penalties for non-performance were agreed upon;

- Weakness in the step-in right clause, which could only be triggered if the concessionaire fails to provide service for 15 days;

- Insufficient financial provisions for the step-in right case, which envisages the concessionaire to compensate the concedent for its expenses up to the amount of gross revenue collected for the service, giving the concessionaire an incentive to walk away if the railway is unprofitable;

- The right of the concessionaire to request indemnification against the loss of power supply.

\section{Box 3: Armenia's Railway-Background}

Armenia's railway network plays a crucial role in providing mobility for people and freight. Armenian Railways was established in 1991 as a closed joint-stock company. Prior to independence, it was part of the Trans-Caucasus Railway, headquartered in Tbilisi, Georgia, which also included the Azerbaijani and Georgian networks. Most of Armenian Railways was built during the Soviet era. With rail chosen by central planning as the primary mode of transport, little emphasis was placed on costs. The system was designed to handle large traffic volumes, and in some cases it served remote areas.

The railway system transports more international than domestic freight. Almost 65 percent of all rail freight is international, of which about 45 percent consists of imports. Although Armenia still relies on its railway system for about 70 percent of imports and exports, railway operations have shrunk ten-fold since independence in 1991, primarily due to the closing of Armenia's borders with Azerbaijan and Turkey. The decline in freight reflected the loss of transit traffic, the dramatic decline in rail-based industries, an improved road network, and strong competition from the trucking industry. An increase in private car ownership and the introduction of minibuses contributed to the passenger decline.

Armenia's railway network length is $732 \mathrm{~km}$, of which only $370 \mathrm{~km}$ are fully operational. The infrastructure and fleet of cars are dated, with most of the electric locomotives around 35 years old and in need of repair or replacement. Track speed is often limited to $30 \mathrm{~km}$ per hour, with

${ }^{14}$ The contract has been modified three times, but these modifications were not available at the time of this assessment. 
rehabilitated sections allowing $60 \mathrm{~km}$ per hour. Several lines are little used because of border closures or loss of traffic. The railway had 4,500 employees before the 2008 concession contract; currently it has 3,370 employees, while outsourcing some functions.

Faced with competition across the Caucasus for regional transport, Armenia is determined to develop transit routes across its territory that will provide shorter links and faster service. The modernization of the existing railway infrastructure is a key part of this strategy and the government sees the need for a large and efficient railway-road intermodal terminal in Yerevan or Gyumri. The growing mining industry in southern Armenia is emerging as a major market for freight service, as the output needs to be transported to ports on the Black Sea. However, Armenia's closed borders with its neighbors have caused high transport costs that make shipping goods through the country highly challenging. About 30,000 containers are imported annually through Georgia's port of Poti on the Black Sea, and railway transport handles about 30 percent of them. The potential capacity, however, is 800,000 tons worth of international containers. Should the Turkish border reopen, there would be new opportunities for freight traffic through Turkey, the rest of Europe, and beyond, since Armenian shipping could go through Mediterranean rather than Black Sea ports.

3.17. Investment has increased substantially following the concession, reaching a cumulative figure of around AMD 98 billion from 2008 to 2014. It also appears that the concessionaire has fulfilled contract obligations. According to a 2014 activity report, as of September 2014, investment commitments are met by 100.4 percent. $^{15}$

15 Due to missing data, a more detailed assessment cannot be carried out of the timing of investment and conformity with the investment plan in the original concession agreement. 
Figure 24. Capital Investment in Armenian Railways

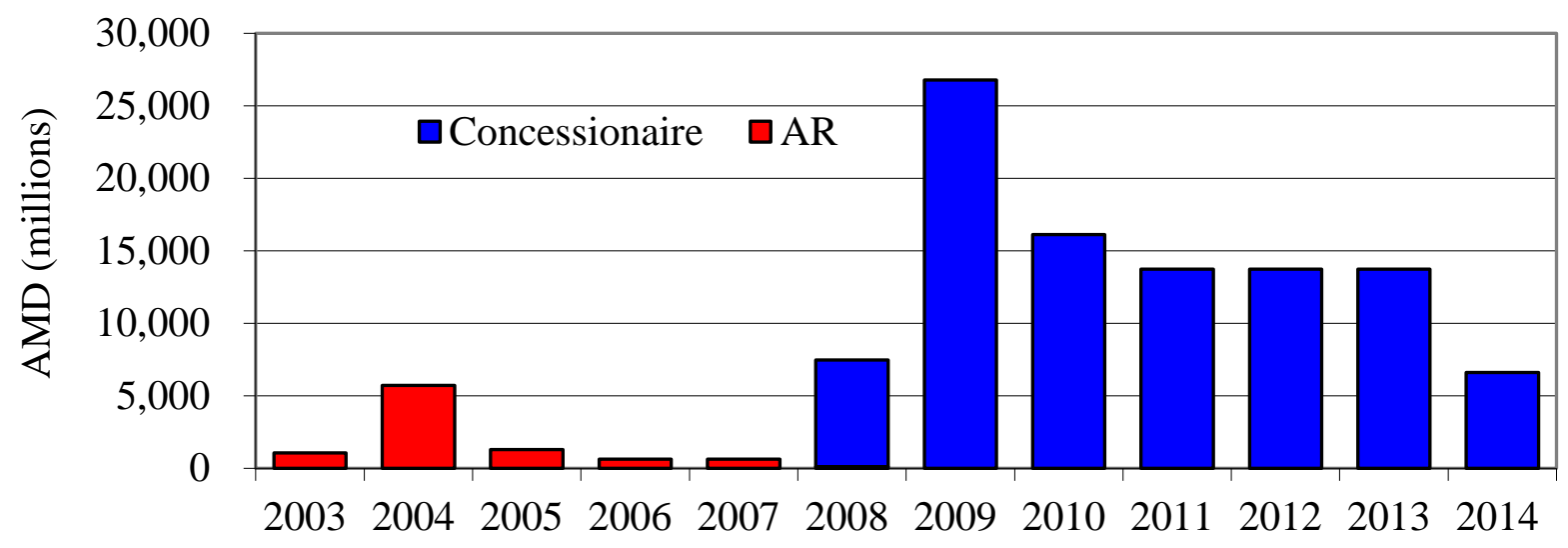

Source: South Caucasus Railway Company.

(*)Due to lack of annual data, 2011, 2012, 2013 figures reflect the annual arithmetic average of the 2013-2010 cumulative figure obtained from a 2014 activity report.

3.18. The concession contract has not impacted the traffic figures; rather, the traffic followed the country's macroeconomic fluctuations. Freight carriage, which is accepted as a close proxy for economic activities, was almost fully reflective of the economy's upturns and downturns. On the passenger transport side, ridership has been on an upward trend, but after the drastic jump in 2008-2010, traffic has been relatively steady and conforming to macroeconomic trends. Although the jump in 2008-2010 might be attributed to the concessionaire's initial investments or expansion of passenger services (subsidized by the government), sufficient data is not available to validate this. ${ }^{16}$

Figure 25. Freight Traffic (right panel) and Passenger Traffic (left panel)

\footnotetext{
16 The Railway Company's performance needs to be measured with various metrics, of which traffic is one. Data availability permitting, the team could have added some measures of operational efficiency and financial indicators to the analysis to also document the modal share of rail in freight and passenger sectors since the concession agreement was signed. Growth on traffic at the same rate as GPD can be considered as a positive outcome, since many railways worldwide are losing market share to road transport and not growing as fast as GDP. From this perspective, traffic growth in Armenia may be viewed as a good outcome, as rail is not losing its market share. However, there may nonetheless be missed opportunities on the carriage of containers.
} 


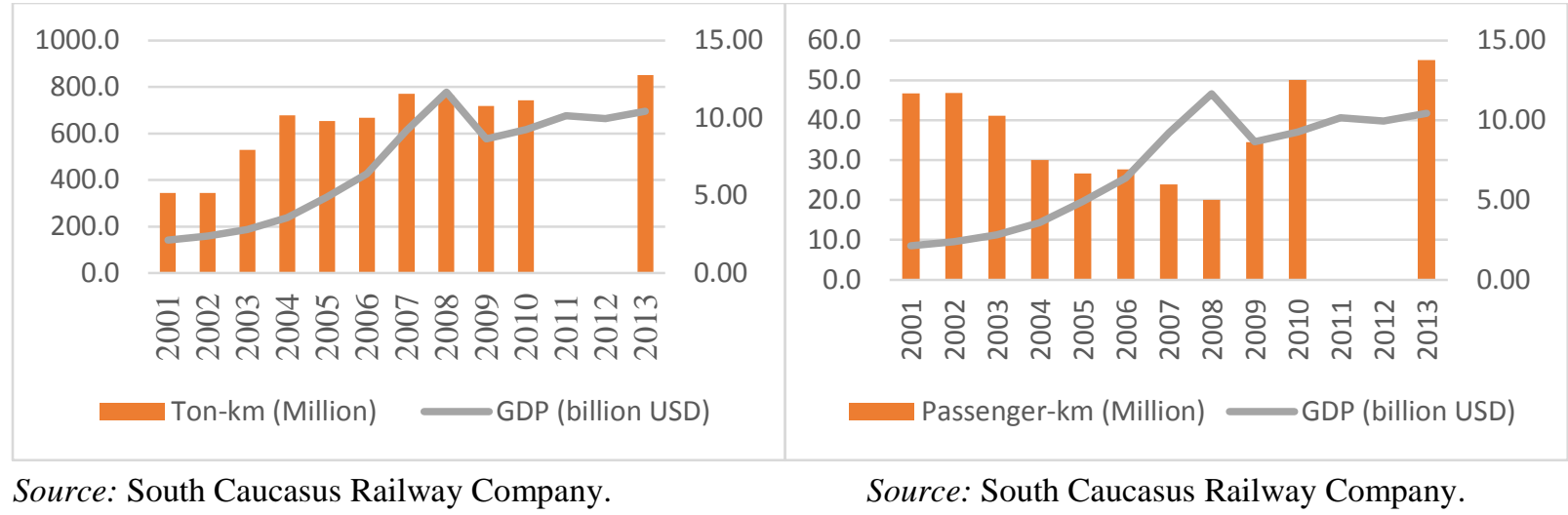

3.19. The contract set the annual concession fee at 2 percent of gross revenue excluding passenger revenue. The GoA also committed to subsidize the concessionaire's loss for operating passenger services with an increasing rate (10 percent in 2009-2010 and 30 percent by 2016), up to the amount of the annual concession fee. Although low traffic has led to loss-making passenger services and the subsidy rate has progressively increased as per contract, a cap to the concession fee has limited the negative impact on the government's budget.

Figure 26. Concession Fee-Subsidy Balance

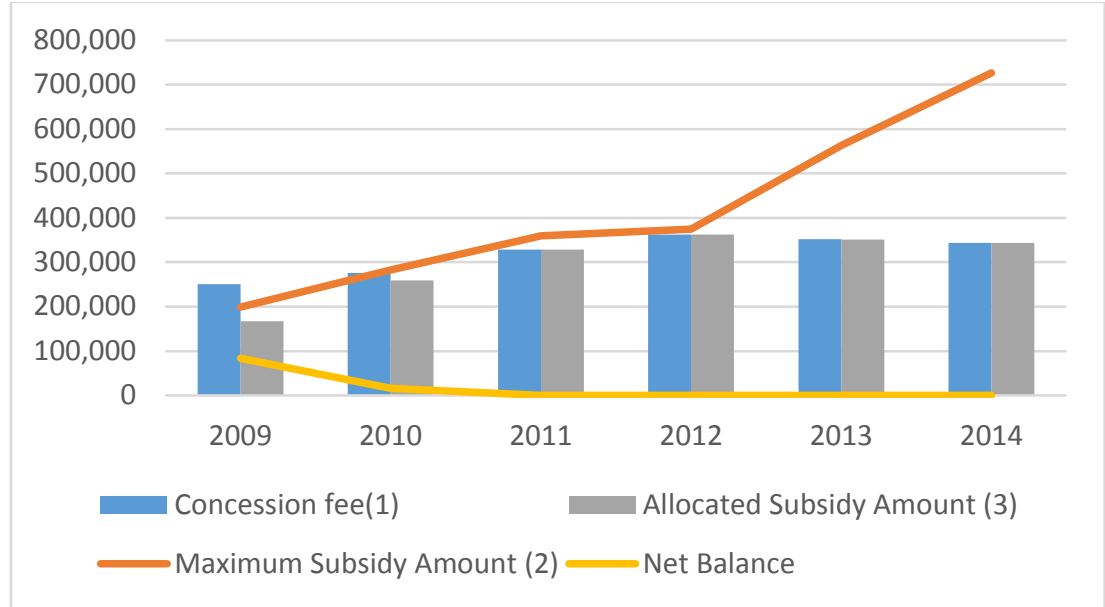

Source: South Caucasus Railway Company.

3.20. Five main challenges and recommendations for fiscal sustainability in the railway sector stand out:

1. The need for a strategic vision. No strategic document exists for the development of railways. Yet the railway system is handling a critical amount of strategic freight traffic (e.g. fuel and wheat imports), and for that reason it is a key player in Armenia's intermodal logistics network. The GoA has managed to agree with the concessionaire on targeted 
investment in various infrastructure areas of need and on the commitment to inform the government and obtain its consent before these investments happen. Currently, the GoA intends to turn the South Caucasus Railways into a national carrier (and rebrand it "Armenian Railway").

2. Underperformance in container and passenger traffic. The railway has not experienced the substantial performance improvements expected from the concession agreement. Railway freight has mostly followed the macroeconomic trends-the unexpected decline in economic activity brought by the 2008 global crisis and the slow pick-up thereafter followed by minor fluctuations in recent years. This underperformance is mostly due to tariff and organizational issues - one such issue being the 100 percent advance payment requirement for freight carriage. After the drastic jump in 2009-2010, passenger traffic has been relatively smooth and conforming to macroeconomic trends, yet with progressive accumulation of operational losses. The GoA is committed to subsidizing passenger services annually; however, due to the concession fee cap, the allocated annual subsidy has fallen short in terms of covering actual losses over the past few years (for instance, in 2014 the allocated subsidy was AMD 350 million, while the actual loss was AMD 726 million). This seems to have no detrimental effect on the government budget, but it jeopardizes the long-term financial sustainability of the concessionaire and calls for a reassessment of the passenger services portion of the concession. The government could identify a smaller and more useful set of passenger trains that would increase ridership while reducing losses for the concessionaire.

3. Investment commitments vs. efficiency. According to the concession agreement, the concessionaire is to invest about $\$ 200$ million in the first five years and $\$ 400$ million over the course of 30 years. As of September 2014, the concessionaire has invested \$205 million, meeting its commitments by 100.4 percent. ${ }^{17}$ However, the productive efficiency of these investments is not clear, and the South Caucasus Railway has been accumulating losses over the years.

4. Concession agreement shortcomings. Neither the GoA nor the concessionaire is satisfied with the actual concession. The concessionaire is concerned that a return to investment will never materialize. The authorities also see several shortcomings of the concession agreement (the concession contract has been amended three times). In general, it is felt by the government that the concession contract does not allow for proper monitoring and the exercise of its contractual rights. There is a lack of clarity in the contract on how to oversee investment commitments, whether they are channeled to the required areas, and on how to link investment with operational performance.

5. The GoA's (legal, financial, etc.) capacity to supervise the concession contract. The monitoring over the concession contract and the performance of the concessionaire is carried out by the Railway Department at the MOTC. Currently, it has seven staff members

${ }^{17} 2014$ Activity Report of joint-stock company South Caucasian Railways. 
and two short-term consultants. They clearly lack the legal, financial, and other required capacities to properly monitor the contract. The unit was established in 2010, two years after the concession contract was launched. A recent "independent" audit of the concession that was commissioned by the GoA has revealed issues in the reporting of the company's financial accounts. The SCR and Armenia's Ministry of Transport and Communications (MOTC) need to cooperate closely to make the concession a success and to fulfill as much as possible the railway's potential as an asset to the economy.

\section{Metro}

3.21. Most metro systems around the world are unable to cover their operating costs with fare box revenues, and Armenia is no exception. According to data from the international benchmarking programs CoMET and Nova, tariff revenues cover an average of 75 percent of operating costs, while other commercial revenues provide about 15 percent, resulting in an operating deficit of 10 percent. ${ }^{18}$ This funding gap is an impediment to maintaining service quality and addressing growing urban mobility needs. The underfunding of transit systems can become chronic, as public budgets are under growing pressure and the most direct solutions for increasing revenues are hard to implement. Increasing fares, for instance, has not only proved to be politically difficult, but also with disproportionate effects on the poor, the segment of the population that uses public transport the most. Charging a price that fully covers the social cost of private vehicle usage (i.e., congestion charges) as a way to fund transit is also politically sensitive.

\subsection{Armenia's urban transport system has changed dramatically since the fall of the} Soviet Union. Since 2002, most bus lines in Yerevan and other major cities have been franchised to private operators on a per route basis under 3-4-year concessions. The demand for public transport has changed dramatically with the introduction of minibuses and a sharp decline in large bus, trolleybus, and metro services.

\section{Box 4: Urban Transport Modes}

Urban transport in Yerevan consists of several different modes, each operated as if they were a stand-alone network without regard to any other mode and without any integration. There is no fare or ticket that permits transfer or multi-modal travel-a passenger must pay again to travel on a different route or mode. Therefore each mode competes against each other rather than each performing the task it is best suited for.

Minibus: All minibus services are tendered by Yerevantrans, an arms' length agency of the municipality which tenders all bus and minibus routes, which means that the city can and does determine where they operate. Yerevantrans contracts routes for 3-4 years and vehicles cannot be older than 15 years. There are now about 1600 minibuses used in Yerevan of widely ranging ages operating on 81 minibus routes. Passengers pay a flat AMD 100 fare to use minibuses,

\footnotetext{
${ }^{18}$ There are examples of metro systems that do recoup their operating costs, such as Santiago de Chile and Hong Kong, but others like the Mexico City Metro only cover half of their operating expenses with fare revenues.
} 
which they pay in cash to the driver on alighting. No tickets are issued and no transfers or season tickets are available. The use of minibuses has few advantages, primarily that of allowing passengers to complete their journeys without changing and allowing the city to operate a network without recourse to subsidy and as a revenue stream. The disadvantages with their operation include slow service, difficulty to board and alight, large numbers causing congestion, particularly at city center bus stops, and possible safety issues combined with poor quality rides.

Metro: Armenia's metro opened in stages from 1981 to 1996 and it has 10 stations. The metro runs on a north-south corridor and was built as line one of a three-line network. Its function was to link the residential suburbs of the north and the south-west with the city center and the large industrial areas in the south. Trains run every 3.5 minutes in the peak and every 5.5 minutes off peak. The fare charged is AMD 100.

Trolleybus: The Yerevan Electric Transport Company operates the five functioning trolleybus services; however, the poor condition of the rectifier stations, overhead wiring, and feeder cables suggests that, unless this infrastructure is renewed, the network may close in the next few years. The number of annual passenger turnover carried has slightly declined, from 5.39 million in 2013 to 5.35 million in 2014 (a decline of 0.7 percent). The fare charged is AMD 50.

Bus: The existing bus company owns a number of minibuses (21-23 seaters), which it leases to private operators; hence it does not operate any bus routes. A number of other private bus companies have bought buses directly from the manufacturer without leasing from the bus company. Bus service routes are generally long - up to $30 \mathrm{~km}$ - crossing the city from district to district; they also suffer from competition from minibuses that ply the same route sections. Passengers pay a flat fare of AMD 100 to travel by bus.

Taxi: Starting in 2007, there has been a noticeable increase in taxi use within Yerevan. In 2004, taxi travel accounted for 19.8 million passenger-km; by 2007, this had increased to 103.3 million passenger-km. The minimum standard taxi fare in Yerevan is AMD 600, which allows $4 \mathrm{~km}$ of travel.

Table B4.1: Passenger Turnover by Transportation Means in Yerevan, 2014

\begin{tabular}{|l|l|l|l|}
\hline Network & $\begin{array}{l}\text { Annual } \\
\text { passenger } \\
\text { numbers } \\
\text { (million } \\
\text { passengers) }\end{array}$ & $\begin{array}{l}\text { Daily } \\
\text { passenger } \\
\text { numbers } \\
\text { (thousand } \\
\text { passengers) }\end{array}$ & $\begin{array}{l}\text { Market share } \\
\text { (percent) }\end{array}$ \\
\hline Bus & 74.5 & 204.7 & 36.4 \\
\hline
\end{tabular}




\begin{tabular}{|l|l|l|l|}
\hline Minibus & 108.9 & 299.2 & 53.2 \\
\hline Metro & 15.8 & 43.5 & 7.7 \\
\hline Trolleybus & 5.4 & 14.7 & 2.6 \\
\hline Total & 204.6 & 562.0 & 100.0 \\
\hline
\end{tabular}

3.23. Yerevan's metro, which is part of the Armenian railway network, started operating in 1981. The metro system has experienced a sharp decline in patronage, not only because of underinvestment, but also because it has limited coverage (only $12 \mathrm{~km}$ and 10 stations), making it difficult to compete with the minibus system, which offers more direct service from point of origin to destination. Each transport mode is operated independently from the others, with no multimodal ticket available. Hence the different transport modes compete with each other. Furthermore, minibus routes not only overlap with the metro route, but stops are not designed to serve the potential multi-modal metro users.

3.24. The metro fare increased in July 2011 (from 50 to 100 drams), which led to a $20-25$ percent decrease in passengers and a 40 percent increase in metro revenues. In 2014, about 16 million people used the metro, down from almost 20 million passengers in 2010. Subsidies from the central budget comprise 58.4 percent of the metro's revenues. The rest of the budget is allocated from ticket purchases, trade, advertisement, and rental revenues. ${ }^{19}$

3.25. The 2009 urban transport roadmap for 2020 in Yerevan summarizes the GoA's vision for urban transport. It proposes a hierarchical and multimodal network combining metro, trolleybus, bus, microbus, and traffic management. This roadmap also includes institutional reforms on the urban transport organization and financing. Strengthening of monitoring and planning capacities is suggested, particularly building a comprehensive database (along with demand forecasts) based on travel statistics, household, and origin-destination surveys. These will create the foundation to be able to design, forecast, and test all new projects as well as measure the benefits and impacts.

3.26. Seven main challenges and recommendations for fiscal sustainability in urban transport stand out:

\footnotetext{
19 The EBRD-supported Metro Improvement Project was launched in 2010, with EUR 15 million allocated for the first stage of the project. The investment helps "the metro security, sustainable development, and energy efficiency." The second stage of improvement work, also worth EUR 15 million, was launched in August 2012. The metro had not undergone renovation since the day of construction.
} 
1. The need for an urban mobility plan. While several assessments have been carried out to inform implementation ${ }^{20}$ the City has is yet to develop a fully-fledged implementation plan for urban transport which also encompasses non-motorized traffic and parking, going beyond the public transport strategic roadmap to implement the vision of an integrated urban transport system. It is planned that a sector regulatory framework will bring both the urban transport service organization and provision to a new quality level. It includes the development of a clear strategy for competitive bus route tendering and support in order to improve the level of service quality being provided across the entire urban bus sector in Yerevan.

Table 13. Yerevan Metro-Main Indicators

\begin{tabular}{|l|l|l|l|l|}
\hline & 2000 & 2005 & 2010 & 2014 \\
\hline Revenue, AMD million & 1328.0 & 1357.0 & 2943.1 & 3725.1 \\
\hline Tickets & 476.3 & 570.8 & 756.7 & 1174.6 \\
\hline Subsidies & 782.7 & 697.0 & 1840.0 & 2175.8 \\
\hline Other & 69.0 & 89.1 & 346.4 & 374.7 \\
\hline \# passengers, ‘000 person & 15476.7 & 15845.1 & 19873.5 & 15818.0 \\
\hline Cost of ticket, AMD & 40 & 50 & 50 & 100 \\
\hline
\end{tabular}

Source: Yerevan Metro CJSC.

2. The need for an integrated ticketing and fare system and coordination between the various modes of urban transport. As no transfers are provided, any passenger wishing to change to a different mode or route would need to pay a second fare. This prevents route planning and contracts planning. However, it will be important to clarify what the cost will be and how the cost will be borne (through external debt, subsidies, or fares or a combination of all three). Ultimately, a higher cost public transport system requires investment and this must be financed.

3. The need for information about existing demand for transport services and affordability, based on passenger data information. The absence of an integrated ticketing system is a constraint to understanding the future travel needs of the city by means of transport modeling given the lack of accurate travel statistics, household, and origin-destination surveys. No information about potential revenue opportunities is available.

\footnotetext{
${ }^{20}$ Asian Development Bank, World Bank among others.
} 
4. Revise the metro tariff system when in competition with minibus routes. The current flat tariff structure of AMD 100 for both the metro and minibuses does not provide incentives to use the metro, since minibuses (1) do not serve the metro stops; (2) overlap with the metro routes; and (3) propose longer routes. Minibuses, however, contribute significantly to urban congestion and pollution. A tax could be levied on minibuses to subsidize the metro, which does not contribute to congestion or pollution.

5. Look at new ways to tap additional sources of commercial revenue and make up for funding shortfalls through agreements with the private sector. Although most examples are concentrated in developed countries, some metro systems in Latin America and the developing world are looking at ways to increase non-tariff revenue. Experience shows that transit agencies in developing countries can gain a lot from becoming more entrepreneurial. Although a metro system's potential to mobilize commercial revenue depends on a lot of factors that take time to change (users' income, space availability, urban density, and system demand), transit agencies can take steps to make the most out of this potential starting with the development of business plans and of smart partnerships with the private sector. Commercial activities will only become a significant source of funding when they are incorporated into system planning from the beginning, and are effectively embedded into the mission and objectives of transit agencies.

6. Introduce Public Sector Service Contracts. Public Sector Service Contracts (PSSCs) awarded to private operators will include provisions to deploy and adopt a city's single service monitoring and fare collection system. The presence of a PSSC for a sector-wide ticketing system could strengthen the success rate of overall public transport reform, by formalizing significant parts of the overall fare revenue and providing an incentive for operators to aim for better performance.

7. Demonstration effect. The development of a new competitive route tendering regime for the private sector bus operators in parallel to a PSSC development process will provide a good demonstration for the rest of the country on how to improve service quality provided by the private sector through a coherent regulatory and contractual framework.

\section{Box 5: Examples of New Ways to Tap Additional Sources of Commercial Revenue}

Advertising: In 2014, the government of Mexico City announced its intention to renegotiate the advertising management contract that it currently has with a private company to increase revenues from over 70,000 advertisement spaces. Technology can also help in generating extra advertising revenues. Madrid will soon launch a system that will display animated announcements along the tunnels of Line 8 and bring an additional \$500,000 a year in revenues. Similar systems are already successfully operating in Beijing and Santiago.

Leasing of commercial spaces: Franchising consultants have indicated that commercial spaces in the metros of Rio and São Paulo are underpriced, with lease spaces per square meter estimated 
to be 30 to 60 percent lower than in a shopping center. The National Public Transport Association (ANTP) of Brazil has reported that various commercial spaces located inside the stations of Belo Horizonte Metro Line 1 are leased at prices significantly below market. In this context, public officials in Brazil are starting to look at ways to maximize revenue from commercial spaces. For instance, the State of São Paulo pushed to increase the share of non-fare revenues in the business model of the recently awarded Line 6 concession.

Naming Rights: The sale of naming rights or branding is also being exploited by various metro systems to get some extra cash. Since 2010, Dubai's Roads and Transport Authority (RTA) has earned more than $\$ 540$ million from the sale of naming rights for 13 metro stations, and from leasing retail outlets inside stations. In some cases, the sale of naming rights also results in added benefits for users. For instance, in 2011, the Baixa-Chiado metro station in Lisbon was remodeled and equipped with free Wi Fi sponsored by Portugal Telecom (PT) as part of an agreement to name the station "PT Blue Station." In India, following the experience of the Gurgaon Rapid Metro, the Mumbai Metro has recently auctioned station naming rights for 12 stations, at prices ranging between $\$ 250,000$ and $\$ 1,000,000$ per year for five years.

Merchandising: The best illustration of a metro systems' merchandising potential is probably the London underground, whose iconic logo and "Mind the Gap" announcement are recognized worldwide. The London Transport Museum earns about \$4 million annually from the sale of official merchandise. Developing city metros are following suit. Six months ago, two years after the São Paulo metro company issued guidelines for the exploitation of products bearing its name, the first store offering metro merchandise opened in the Consolação Station on Line 2 of the city's Metro.

Consulting services and technology sales: Urban transport operators in the developed world have long been offering consulting services internationally, including: RATP (Paris), MTR (Hong Kong), TMB (Barcelona), and Metro de Madrid (Madrid). This last one made about \$25 million from consulting services alone in 2012. Metro companies in the developing world are starting to get into this business, and some of them are even making money by advising their peers on how to boost revenue.

Land Value Capture: An entrepreneurial way of capturing part of the increase in land value that results from transit investments holds the greatest potential for increasing non-fare revenues. This can be done through various transactions with the private sector, including: selling or leasing land, charging real estate developers for the right to build taller buildings and participating in urban redevelopment projects (in Tokyo (Tokyu Corporation) and Hong Kong (MTR Corporation), where the contribution of property and commercial developments to net operating profit has even exceeded that of transport operations. In Latin America, São Paulo sold additional construction rights (known as CEPACs) to private developers, mobilizing about $\$ 100$ million for Line 4 of the city metro. 
Source: Daniel Pulido and Irene Portabales González, World Bank.

\section{Agriculture (Fuel, Fertilizer, Irrigation Water, Loans)}

3.27. Fast economic growth over the last decade has generated new opportunities for the agricultural sector. Higher incomes have increased the level and changed the pattern of food consumption, with a marked rise in the amount that Armenian households spend on food. The Armenian agri-food industry has also undergone transformation during this time, with a two-speed agricultural sector developing. It is currently dominated by small, mixed-income farms, averaging 1.4-1.7 hectares and producing partly for own consumption and partly for sale. However, the benefits of land title registration and the growth of the land lease market have facilitated the emergence of a medium-size, more market-oriented farm segment, with farm sizes in the range of 7-20 hectares or even higher in some regions.

3.28. Subsidies are an important part of Armenia's agricultural development strategy. In 2014, Armenia allocated AMD 2 billion (7 percent of total subsidies) to agricultural credit and irrigation water subsidies, plus additional input subsidies on seeds, fertilizer, and fuel, which are not separately itemized in the budget. The main objectives of the strategy are to increase agricultural GDP and raise food security; an increase in agricultural productivity is seen as key to both of these objectives and hence is the principal goal of the subsidy program.

3.29. Irrigation water is among the most important subsidized inputs for agriculture. The Water Users Associations (WUA) and water supply companies received subsidies of AMD 5.8 billion in 2014 (4 percent of total subsidies), more than double the 0.5 billion in subsidies to these providers in previous years. Because agriculture accounts for 18 percent of Armenia's GDP and 36 percent of total employment ${ }^{21}$, irrigation is a strategic priority for the GoA. Irrigation agriculture accounts for about 80 percent of agricultural GDP, or some AMD 715 billion, against which irrigation subsidies represent around 0.8 percent. Agricultural water management has gone a long way since the transition period, and now secondary and tertiary canals across the entire irrigated area are operated by WUAs. While further progress is needed, the governance system, technical capabilities, and financial viability of WUAs have been gradually improving.

3.30. Currently, subsidies to WUAs and water supply companies enable delivery of irrigation water at a relatively low tariff to farmers. Water Users' Associations benefit both from direct subsidies and from paying a reduced price for the water they receive from the subsidized water supply companies, but even these subsidies do not fully close the gap between revenues and expenditures. Although a high proportion of farmers pay their dues to the WUA, the water tariff of AMD 11 per cubic meter has not changed since 2009 and now fails to cover the WUAs' operating costs, in particular due to rising energy costs. As a result the WUAs have been accumulating losses and debt over time, up to AMD 3.5 billion (9 months' subsidy) in 2014.

${ }^{21}$ Sectoral employment share calculated from Integrated Living Conditions Survey (ILCS) 2013. 
3.31. A strategy currently under discussion considers a gradual increase in water tariffs to improve cost recovery and reduce reliance on state subsidies. Raising irrigation tariffs is a sound proposal for several reasons. First, cheap water encourages inefficient use of the resource, allowing the irrigation of low-value crops where the benefits from irrigation are less than the real cost, and reducing the incentive for farmers to invest in water-saving technologies. Second, the increasing indebtedness of WUAs as electricity prices rise - they rose from 24 percent of total WUA expenditure in 2010 to 34 percent in 2013 - damages their financial health: they already appear to be underinvesting in repairs and maintenance, which now account for only about 15 percent of total expenditures. If this situation is not resolved, then the combination of rising debt and deteriorating infrastructure may threaten their long-term sustainability. Distributionally, most irrigation water subsidies accrue to the larger farms, which may be consistent with the goal of increasing agricultural production, but it indicates that there is relatively little social case for continuation of these subsidies, since 68 percent of users benefit from water subsidies averaging just AMD 7,600 (\$16) per year. ${ }^{22}$ In terms of meeting the income needs of these small and often poor producers, other forms of transfers and social safety nets would be both more efficient and more effective.

Figure 27. Distribution of Irrigation Water Subsidies by Farm Size

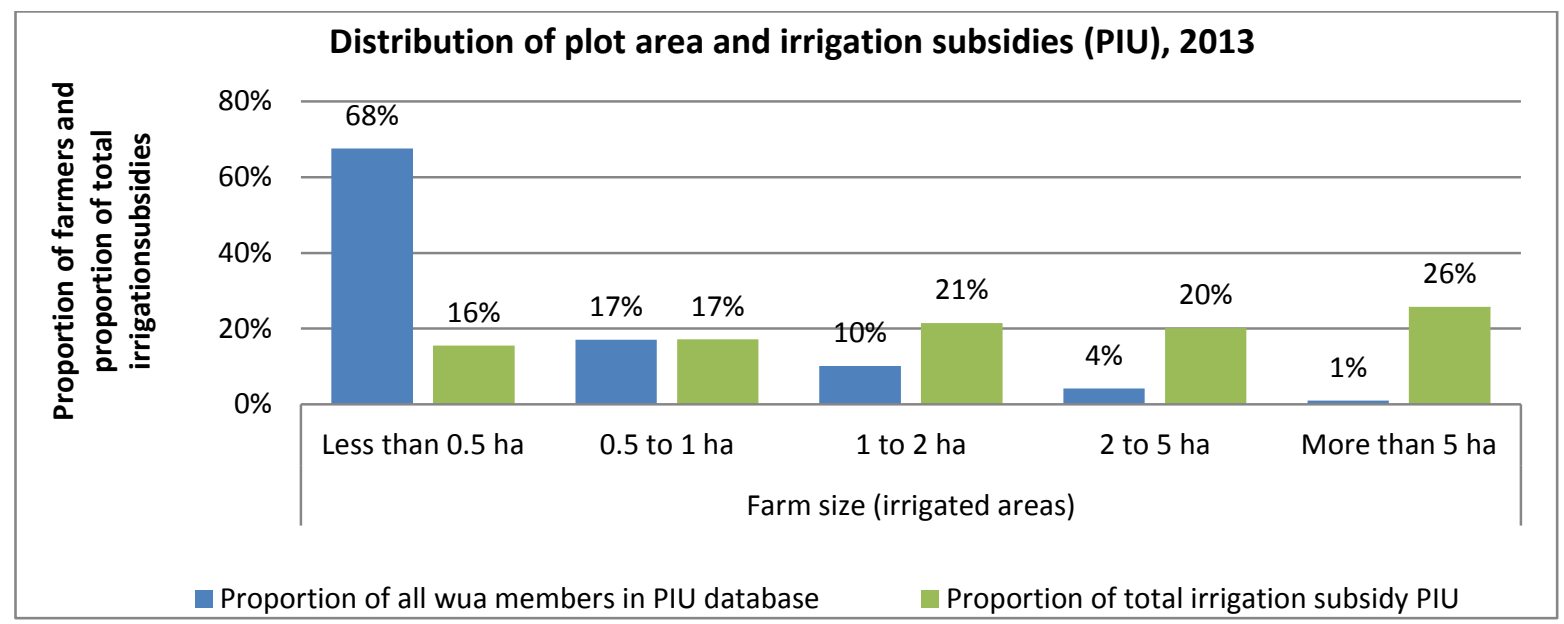

Source: Calculations using Irrigation PIU database.

3.32. Farmers also have access to subsidized fuel and fertilizers, but the annual allocation is unknown. State support programs exist for the production of spring barley, corn, alfalfa, and honey-lotus, as well as for the purchase of affordable diesel fuel and fertilizers. Since 2013, farmer beneficiaries have been paying AMD 350 per one liter of diesel fuel (about 75 percent of market price), AMD 6,000 per one sack of nitrogen fertilizer (35 percent lower than the market price), and AMD 7,000 per one sack of phosphate and potash fertilizers (half the market price).

\footnotetext{
${ }^{22}$ Total subsidy of AMD 4,750 +1,094 $=5,844 \mathrm{~m}$; times $16 \%=935 \mathrm{~m}$ to holdings up to 0.5 ha. Shared between 180,000 x $68 \%=122,400$ users; Gives AMD 7,600 per user $=\$ 16$.
} 
3.33. Finally, under a 2011 government decision, farmers can obtain preferential agricultural loans at the rate of 14 percent per annum (annual allocation of AMD 872 million). Now 6 percent will be paid by the government and the farmers will be eligible for loans at 8 percent. Loans are given in Armenian national currency and the average loan size is AMD 625,000 . The loans have a six-month interest-only grace period and then six months for capital repayment. The additional funding is being disbursed through the Central Bank, which on-lends to respective commercial banks. In 2014, about 80,000 farms out of a total of 330,000 farms in Armenia were granted low-interest loans worth AMD 66 billion. According to the Central Bank, as of late February 2015, agricultural lending stood at AMD 135.8 billion, up 6 percent from the previous year.

3.34. Seven main challenges and recommendations for fiscal sustainability, efficiency, and equity in the agricultural sector stand out:

1. The performance of various subsidy schemes should be assessed together, against the stated objectives of increasing agricultural GDP and food security. In order to increase GDP, the increase in agricultural Gross Value Added from a subsidy must exceed the total cost of the subsidy, including transaction costs, and so this ratio should be regularly monitored. Given that one crop may benefit from multiple subsidies (e.g. on seed, fertilizer, fuel, and irrigation water) all subsidy schemes should be examined together to assess their overall impact and cost. In terms of the objective of increasing food security, agricultural subsidies do not necessarily need to show a net economic benefit (as this is a "spending" policy rather than an "earning" policy), but decision-makers should be aware of the costs of the food security policy and remain open to alternative and more cost-effective means of achieving the same goal.

Table 14. Irrigated Farming Sector-Main Indicators

\begin{tabular}{|l|l|l|l|l|}
\hline Year & $\mathbf{2 0 0 0}$ & $\mathbf{2 0 0 5}$ & $\mathbf{2 0 1 0}$ & $\mathbf{2 0 1 4}$ \\
\hline Number of farmers (water-supply contracts) & 240,000 & 220,000 & 200,000 & 180,000 \\
\hline Land used & 110,000 ha & 125,600 ha & 129,200 ha & 130,500 ha \\
\hline $\begin{array}{l}\text { Efficiency indicators: } \\
\text { - average area for one contracted water user } \\
\text { - cultivation of high-value crops (share of total } \\
\text { land plot) }\end{array}$ & $50 \%$ & $71 \%$ & $80 \%$ & 0.45 ha \\
\hline
\end{tabular}




\begin{tabular}{|l|l|l|l|l|}
\hline $\begin{array}{l}\text { Irrigation subsidies, AMD } \\
-\begin{array}{l}\text { to WUAs } \\
-\quad \text { to supply agencies }\end{array}\end{array}$ & N/A N/A & $\begin{array}{l}5,002 \mathrm{~m} \\
\text { N/A }\end{array}$ & $\begin{array}{l}4,756 \mathrm{~m} \\
0 \mathrm{~m}\end{array}$ & $\begin{array}{l}4,750 \mathrm{~m} \\
1,094 \mathrm{~m}\end{array}$ \\
\hline $\begin{array}{l}\text { Average irrigation subsidy per irrigated } \\
\text { hectare, AMD }\end{array}$ & N/A & 40,000 & 37,000 & 45,000 \\
\hline Subsidies (bank loans to farmers) & N/A & N/A & 0.0 & $873 \mathrm{~m}$ \\
\hline
\end{tabular}

Source: Irrigation PIU, Ministry of Finance.

2. Irrigation water subsidies, the largest portion of domestic funding, hinder the pursuance of more efficient water use. The irrigation service fee is regulated, rather than increasing in line with rising costs, and the difference between fees received and actual expenditure is covered through state subsidies and a growing WUA debt that may one day have to be written off. Where water is supplied to farmers at less than its marginal cost, it encourages over-use, including the cultivation of crops that offer a low economic return to irrigation, and discourages the introduction of more water-efficient practices and technologies. As a minimum, the volumetric tariff for irrigation should cover the full marginal cost of water, including the electricity cost of pumping and any opportunity cost from diverting water to irrigation rather than hydro-power generation. If there is a pressing economic, political, or social case to continue government support to the irrigation sector, it should be directed exclusively at the fixed costs of water supply (such as maintaining the canal network) where the distortionary effect, and hence the net economic loss, is much lower.

3. The current low quality of the irrigation infrastructure system and problems experienced by the sector might make it difficult to implement an increase in tariffs. In 2013, according to household survey data, only 64 percent of WUA members received irrigation water in sufficient quantities and on time (though this indicator improved as compared to 53 percent in 2010). Farmers reported several reasons, including technically deficient waterlines (28 percent of farm households), problems with the local network (22 percent), and pump breakdowns (14 percent). Delivery losses are estimated at around 45 percent; while this is a fairly typical figure for an irrigation system such as the one in Armenia, losses waste not only water, but also the energy spent in pumping water up to that point. Furthermore, in a recent study farmers expressed concerns about paying for water that they did not receive. Timely communication with farmers to spread awareness about availability of water in the system is crucial; metering should also ensure that farmers only pay for the water that they actually receive. In addition, the government can also consider a range of investments in irrigation infrastructure that helps WUAs reduce operating costs, such as reducing transmission losses, decreasing the requirement for pumping, making greater use of lower night-time electricity tariffs, and helping end-users to switch to more efficient application systems, particularly in those parts of the system where water is most costly and farmers grow high-value crops that can justify the investment. All such 
investments require an economic cost-benefit assessment, keeping in mind that the primary goal is not to save water, but to save or make money.

4. It is arguable that irrigation management transfer has been too successful for its own good. WUAs have been set up faster than the water supply companies are able to manage, in order to upgrade as necessary and ensure that their WUA customers have a reliable supply. There may be a case for a rolling program of investment and institutional reform, under which water users would be offered a "new deal": a reliable water supply that lets them plan their production and marketing with confidence, together with fair metering so they only pay for what they use, but matched by higher tariffs that cover the full operating costs and allow for a regular maintenance program to ensure future supply. The institutional challenges of such an approach should not be underestimated, and it might best be introduced on a canal-by-canal basis, starting with the areas where irrigated agriculture is most profitable and where farmers are most likely to accept the higher costs associated with the higher level of service.

5. Input subsidies in general, whether for irrigation, fertilizer, or fuel, tend to encourage over-use of the input and the relative growth of high-input systems, which may not always align with development priorities. Even if subsidies succeed in improving productivity or food security, it might be at a high cost, while another instrument might be more cost-effective. More importantly, input subsidies can mask the underlying unprofitability of some farming systems, hence obstructing necessary change rather than taking advantage of the government's (limited) funds to make improvements in the agricultural sector.

6. The current "one-size fits all" approach to subsidies inhibits the ability of the government to implement targeted policies appropriate to the needs of small-scale, mixed-income holdings on the one hand, and emerging medium-sized, more market-oriented farms on the other. While the small farms would benefit from improved technologies, better farming practices and enhanced access to markets, many are so small that agriculture alone will never provide a satisfactory household income. For most of these cases, the route to higher living standards lies in the movement of labor out of agriculture and into more productive sectors of the economy, a transition that is aided by the relatively young age structure of the rural population. Policies to encourage this could see a gradual withdrawal of subsidies that encourage people to continue in rather low-productivity agriculture. A reallocation of these resources toward measures that support the development of non-agricultural employment and its accessibility to the farming and rural population could also result from new policies.

7. A movement out of agriculture, in line with long-term trends for high- and middle-income countries, should free up land for expansion of the emerging medium-sized sector with its more capital-intensive, labor-efficient technologies. This sector has massive investment needs-in production, on-farm storage, and marketing - which the government could help to address through both development of the credit market and targeted investment measures. In both respects, policies should seek to 
foster the development of efficient and competitive markets, and to minimize the distortions and high transaction costs that are all too often associated with grant schemes. Particularly important for this segment are the downstream processors and traders who are starting to play an active role in better market integration and create the conditions under which farming itself can prosper; policy makers should recognize this and ensure the conditions for healthy development of the whole value chain are present.

\section{Drinking Water $\underline{\underline{23}}$}

3.35. The water and sanitation services (WSS) sector has seen remarkable improvements over the last decade. The GoA has restructured, reformed, and invested in the sector in ways that have improved access, continuity and quality of water, and sanitation services. Nevertheless, challenges in the sector remain. Tables 15 and 16 summarize improvements that have taken place under the two largest service providers in the country, AWSC and Yerevan Djur and AWSC.

Table 15. Improvements in the WSS Sector since 2000 - Yerevan DJUR

\begin{tabular}{|c|c|c|c|c|c|}
\hline Standards & Unit & $\begin{array}{l}\text { One year before } \\
\text { private sector } \\
\text { involvement } \\
(2000)\end{array}$ & $\begin{array}{l}\text { At the end of the } \\
\text { management contract } \\
\text { with a utility } \\
\text { (2005) }\end{array}$ & $\begin{array}{l}\text { After } 4 \text { years of } \\
\text { Lease Contract } \\
\text { (Véolia Water) } \\
\text { (2009) }\end{array}$ & 2014 \\
\hline Water supply duration & Hours & $4-6$ & 18.4 & 20.4 & 23 \\
\hline $\begin{array}{l}\text { Compliance with water } \\
\text { quality requirements }\end{array}$ & $\%$ & 94.5 & 97.2 & 97.8 & 99 \\
\hline Energy consumption & Million- kwh & 240.3 & 124.2 & 109.6 & 28 \\
\hline Collection efficiency & $\%$ & 21 & 86 & 97.6 & 99.4 \\
\hline Installed water meters & $\%$ customers & 0.8 & 87 & 96 & 98 \\
\hline
\end{tabular}

Source: State Water Committee of the GoA

\footnotetext{
${ }^{23}$ This section draws from the Armenia Water Sector Tariff Study, World Bank, 2015.
} 
Table 16. Improvements in the WSS Sector since 2000-AWSC

\begin{tabular}{|l|l|l|l|c|}
\hline Indicators & Unit & $\begin{array}{l}2004 \\
\text { Base Year }\end{array}$ & 2009 & 2014 \\
\hline Water supply duration & Hours & $4-6$ & 12.8 & 16.8 \\
\hline $\begin{array}{l}\text { Compliance with water } \\
\text { quality requirements }\end{array}$ & $\%$ & 93.8 & 98.4 & 99 \\
\hline Collection efficiency & $\%$ & 48 & 84.1 & 93 \\
\hline Installed water meters & $\%$ customers & 40 & 72.3 & 95.2 \\
\hline
\end{tabular}

Source: State Water Committee of the GoA

3.36. Five water utilities currently serve 75 percent of the population of Armenia under three public-private-partnership (PPP) contracts. ${ }^{24}$ There are 560 villages outside the areas served by PPPs. These villages have independent arrangements to obtain water supply (Figure 28). 35 illustrates the institutional arrangements and coverage of the service areas.

Figure 28. Water and Sanitation Service (WSS) Providers
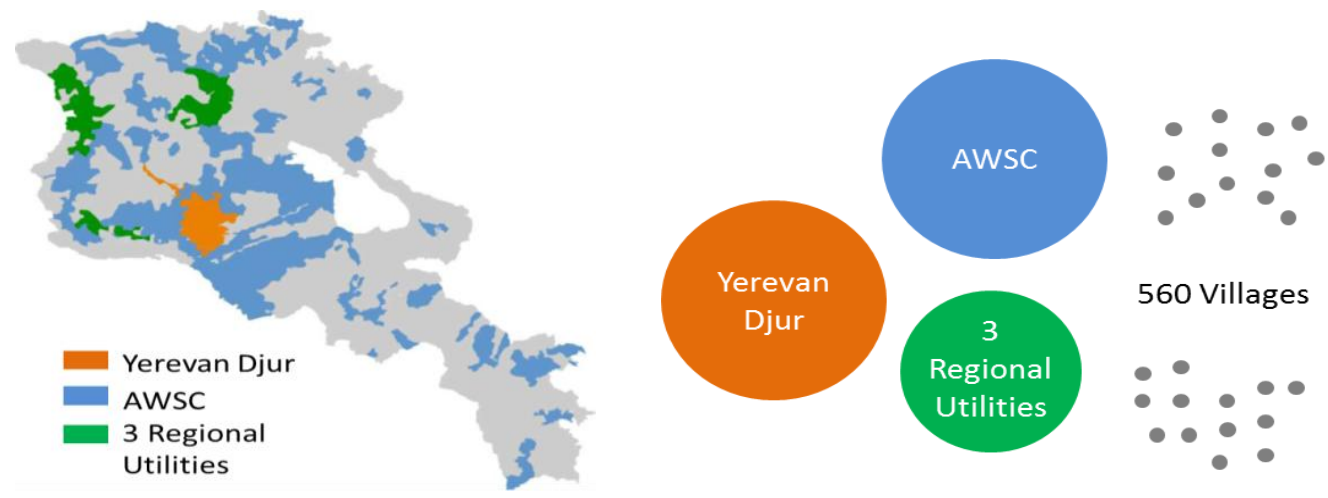

Source: Armenia Water Sector Tariff Study, World Bank, 2015.

3.37. Nine main challenges and recommendations for fiscal sustainability, efficiency, and equity in drinking water sector subsidies stand out:

24 The following PPP contracts currently exist: (1) Yerevan Djur, which serves 1.07 million people in Armenia's capital, is operated under a lease contract with the French company Veolia; (2) Armenia Water and Sewerage Company (AWSC), which serves 640,000 people, is operated under a management contract with the French company SAUR; and (3) three regional utilities (Nor Akunq, Lori, and Shirak), which serve 421,000 people, are operated under a management contract with the German company MVV. 
1. Revenues in the sector fall well short of costs, requiring direct fiscal subsidies as well as "quasi-fiscal" subsidies, due to the deterioration of infrastructure. Under-investment in maintenance and rehabilitation has caused the deterioration. Revenue from tariffs in Armenia covered only 67.3 percent of the sector's total costs in 2012. Even after government subsidies, the water sector had a shortfall of AMD 3.38 billion. As a result, revenues fall far short of recovering operating and maintenance costs. Revenues also do not meet the investment costs necessary for the rehabilitation and expansion of network coverage.

2. Costs, meanwhile, will likely continue to climb. The grace period on several large loans - those used to finance improvements in service - ended in 2015. This will result in a higher cost of debt service for the service providers. Moreover, investment needs-for which new loans will be needed - are still substantial. More than 800,000 people in 560 villages live without access to centralized water and sanitation. Within the areas covered by centralized service there are problems with continuity of supply, pressure, and unsanitary discharge of wastewater.

3. Higher costs of service will need to be passed through into customer tariffs or subsidized by the GoA. This presents the GoA with two distinct challenges: (a) How to protect the poorest members of the population from tariff increases that make water and sanitation (or other basic needs) unaffordable; and (b) How to avoid the rate shock which can come with sudden, large tariff increases and make reform difficult.

4. Institutional changes also present challenges. The three PPP contracts will end in 2016 and be retendered. Before bidding, potential investors will want to have a clear idea of the costs of service going forward and what subsidies (if any) can be expected from the GoA to cover the gap between the cost of service and customer tariffs. The government, for its part, wants to know what level of tariffs customers will be willing and able to afford. If subsidies are required, they will want to know the anticipated fiscal burden.

5. The existing system is likely to be inequitable. Drinking water tariffs are uniform across the country. That means that the largest consumers benefit most from the subsidized tariffs while they are also likely to be better-off. From an equity standpoint, the less well-off farmers should benefit more from public subsidies, while those who can afford it should pay a market price.

6. Water tariffs should be increased to cost-recovery levels. Tariff reform is necessary to increase access, quality, and reliability of water services in Armenia. But it can disproportionately impact the poor and lead to social unrest if mitigation measures are not put in place, such as those recommended below (7-9).

7. Highly targeted subsidies should be provided for vulnerable households. Designing a subsidy regime requires decisions about: (a) how to identify the poor; (b) how to deliver the subsidy; (c) when to deliver the subsidy; and (d) how to fund the subsidy (see Annex 3).

8. Increases from current tariffs to cost-recovery tariffs should be gradual. Increases need to take into consideration three important issues: (a) how to keep water affordable for as much of the population as possible; (b) how to prevent "rate shock," or customer discontent 
over sudden, substantial tariff increases; (c) what will be the cost of subsidies to the sector under each tariff transition program.

9. The government should conduct transparent and sustained communication with the public. Regardless of the transition option chosen, a critical component of tariff reform is a well-coordinated communication campaign. It is important for customers to understand: (a) what is changing and why; (b) what is the long-term plan; (c) what will be the expected benefits of the plan; and (d) how much tariffs will increase in the upcoming five-year period. It takes time to build public support for tariff reform. Public communication should be sustained throughout the transition period, and showing links between higher tariffs and noticeable service improvements will be crucial to success.

Figure 29. Service Provider Operating and Capital Expenditures versus Tariff Revenue (2012)

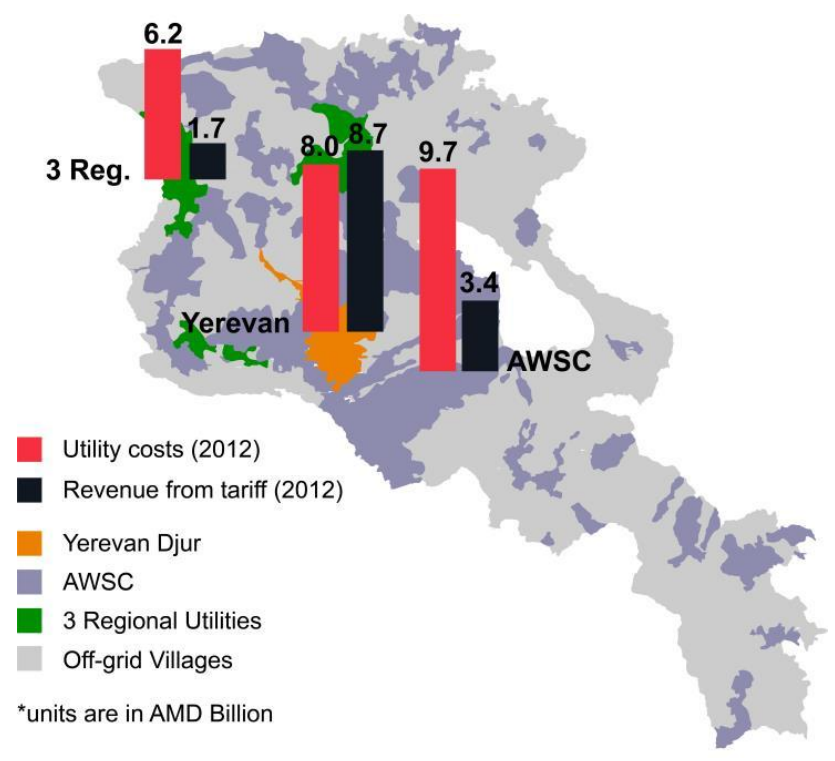

Source: Armenia Water Sector Tariff Study, World Bank, 2015.

\section{Social Sector (Childcare)}

3.38. The GoA has embarked on a reform of its child welfare systems. The aim is to develop a system of family and child support services and family-based care for children without parental care that would gradually replace the system of residential care, which remains the predominant child protection service. This reform is in line with government policies, but has advanced slowly with different levels of success and speed. As part of the child welfare reforms, a plan was adopted in 2006 to secure the rights of children through the closure of orphanages or their conversion into family and child support institutions. In this regard, an important achievement in the reform of child protection services is the deinstitutionalization of residential care institutions, which has led to the restructuring of 17 boarding schools in 2007 and the reintegration of approximately 4,000 
boarding school students into their biological families. More recently, the laws on social assistance and general education provide for the principle of "inclusive education," that is, the right for children with special needs to access the regular education system outside specialized institutions.

Table 17. Social Sector-Main Indicators

\begin{tabular}{|l|c|c|}
\hline Year & 2010 & 2014 \\
\hline \# institutions (Ministry of Economy/MoE) & & 27 \\
\hline \# children 1/ & 28 & 2247 \\
\hline $\begin{array}{l}\text { \# institutions (Ministry of Labor and Social } \\
\text { issues/MoLSI) }\end{array}$ & 18 & 17 \\
\hline \# children & 1960 & 1855 \\
\hline Total subsidies, AMD million ${ }^{2}$ & 1576.1 & 2077.8 \\
\hline Subsidies (per child, per months), AMD & 67011 & 93340 \\
\hline
\end{tabular}

Source: National Center for Education Technologies, Ministry of Labor and Social Issues, Ministry of Finance.

${ }^{1}$ Data for 2010-2011 and 2013-2014 academic years,, respectively.

${ }^{2}$ For full-day child care institutions.

3.39. Nevertheless, there are still around 5,000 children in Armenia who spend all or most of their time in residential childcare institutions, such as orphanages and boarding schools. About 800 children are in orphanages, managed under the Ministry of Labor and Social Issues and about 4,200 are in special institutions, under the Ministry of Education. Over 80 percent of children in orphanages have at least one living parent. These institutions are State Non-Commercial Organizations and they receive subsidies according to cost norms per child. Government subsidies cover 100 percent of their operational costs, accounting for 12 percent of total public subsidies.

\section{Box 6: Childcare Services: Institution versus Family-based-International Experience}

In addition to emphasizing the benefits of developing quality child welfare systems focused on family alternatives, studies underscore the importance of moving children out of institutions and into such arrangements as soon as possible. Another challenge for nations in building child welfare systems, therefore, is to develop policies that strike a balance between the custody rights 
of birth parents and children's best interests, while keeping the time children spend in institutions awaiting placement to a minimum. As the research makes clear, the best outcomes for children occur when they are raised in an environment that is safe, provides them with basic necessities, such as adequate nutrition and medical care, and offers them a family-like atmosphere in which they regularly interact with caregivers who are warm and responsive to their needs.

Research shows consistently that family-based (adoption or foster care) offers children better outcomes than what they would be expected to experience if raised in orphanages or other institutions. In general, the quality of foster care tends to matter. Dramatic improvements occur when infants and young children leave an institution and are placed with adoptive families or high-quality foster homes. The studies reporting such improvements involved children who were placed with families that provided much better conditions than those they experienced in institutions. The children showed immediate and significant gains in physical and behavioral growth and became attached to their new parents.

But many more children remain in institutions than are adopted or placed in foster care in most countries. For them, research suggests, interventions that improve the quality of their interactions with their caregivers can be critical to their developmental outcomes. Studies of interventions aimed at improving the outcomes of institutionalized children vary. But what emerges is evidence suggesting that, in practice, the quality of care may be more important than the type of care.

Research also demonstrates the importance of improving children's environments as early in their lives as possible. The long-term development and adjustment of institutionalized children tend to be influenced by how long they are exposed to conditions that deprive them of the interactions, warmth, and other factors important to healthy development. In general, children removed from institutions at a young age tend not to have long-term deficits. But the age at which long-term deficits become a significant risk often depends on the severity of their experiences in the institution. That "step," for example, can occur in as little as six months for children in extremely depriving conditions, such as those characteristic of Romanian orphanages several decades ago.

Helping nations develop comprehensive and professional child welfare systems with an emphasis on family alternatives over institutional care is an endeavor several international and national organizations, as well as private foundations, are undertaking, including UNICEF.

Source: "Understanding Institutionalized Children: Developmental Issues, Intervention and Policy Implications," Special Report in the November 2012 issue of the Office of Children Development newsletter.

3.40. Two main challenges and recommendations for fiscal sustainability in the social sector (childcare) stand out: 
1. One important remaining stumbling block in achieving the goals of reform is the need to redirect budgetary resources from residential care to the new set of community-based and family-oriented services. Several studies elsewhere have demonstrated that the goals of this reform will have a positive effect on child well-being and development while at the same time providing a more cost-efficient set of services. This latter consideration is especially relevant when taking into account the economic challenges and constrained fiscal space that Armenia faces. A 2010 UNICEF study demonstrates that family-based foster care would be actually more efficient in the long term, that is, it would provide better quality services while allowing significant savings (Figure 30).

2. Lastly, and quite importantly, a roadmap to fully transition to a family-based childcare model is yet to be developed-including how and within what timetable to close, transform, or downscale the remaining residential care institutions. This is particularly important, since transitioning to a full-fledged family-based model takes time and requires resources that need to be tabled. For example, a number of new community-based social services, such as family and child support services and alternative family-based substitute care services, need to be created on a national scale and in sufficient numbers to overcome the prevailing overreliance on residential care for children at risk in Armenia. As the country moves into such an operational phase of reform it will face the same challenges as many other countries have faced. One of these is linked to financial constraints. It will not be possible for the country to sustain full funding to residential care institutions, while at the same time taking on the commitment to scale-up new services. It is therefore important that the planning of the continued reform is carefully articulated.

Figure 30. Potential Savings from Moving to Family-based Childcare

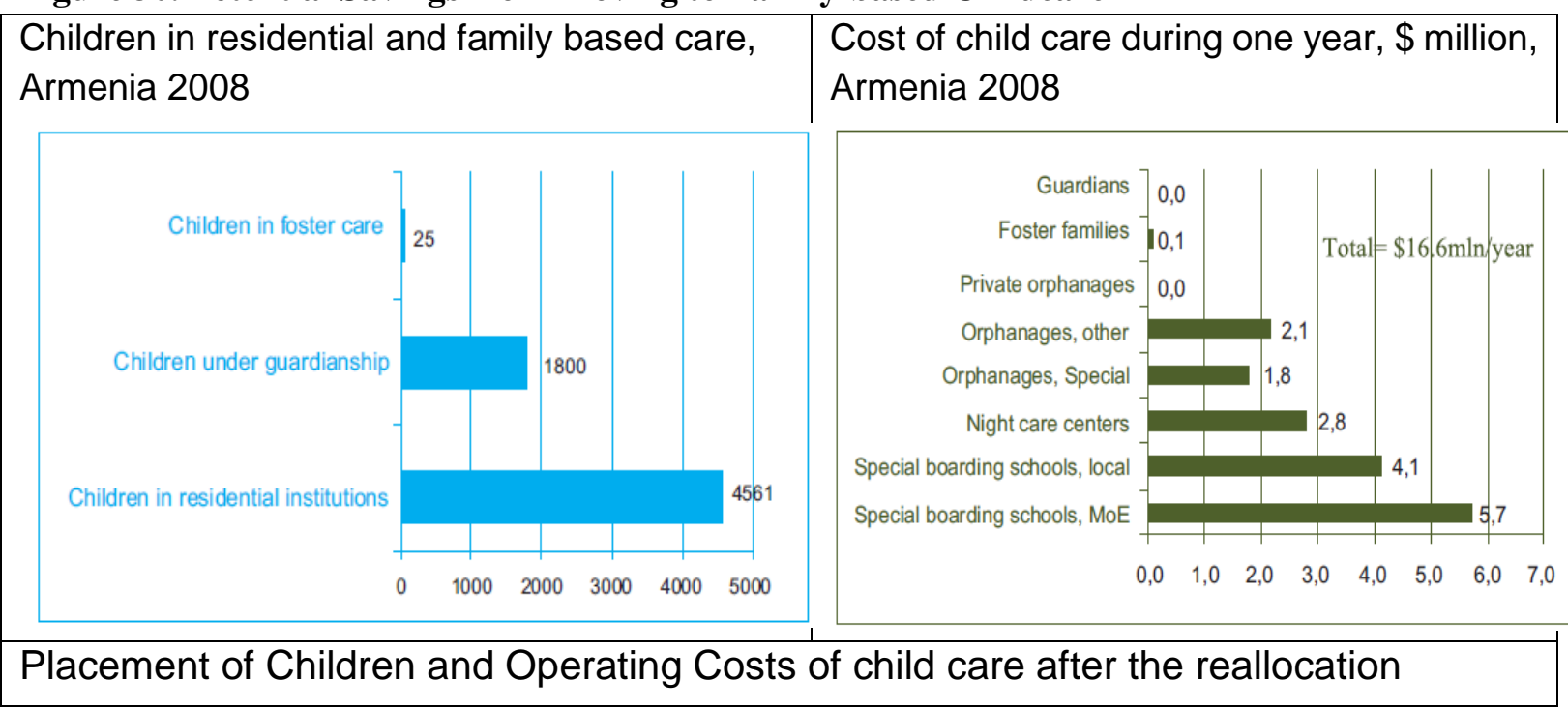




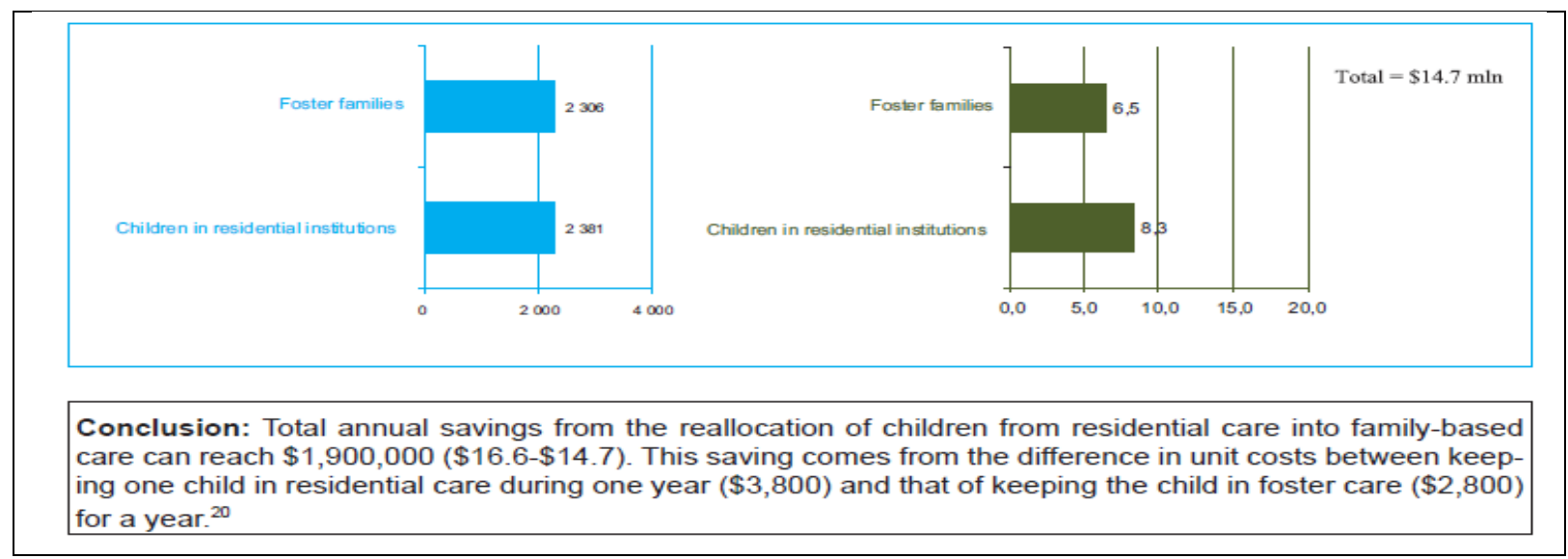

Source: UNICEF-Armenia, "Towards alternative child care services in Armenia: costing residential care institutions and community based services," 2010.

\section{Summary of the Options and Recommendations}

\subsection{Table 18 below summarizes the advantages and disadvantages of the mitigation mechanisms described in the previous sections.}

Table 18. Advantages and Disadvantages of Mitigation Mechanisms

\begin{tabular}{|c|c|c|}
\hline $\begin{array}{l}\text { Mitigation } \\
\text { mechanism }\end{array}$ & Advantage & Disadvantage \\
\hline $\begin{array}{l}\text { Indirect } \\
\text { delivery }\end{array}$ & - Easy to administer & $\begin{array}{l}\text { - Weak targeting of poor households } \\
\text { - Must be accompanied with performance } \\
\text { benchmarking to separate efficiency and } \\
\text { subsidy considerations }\end{array}$ \\
\hline $\begin{array}{l}\text { Lifeline } \\
\text { tariff }\end{array}$ & $\begin{array}{l}\text { Can be administered by utility; } \\
\text { does not require separate subsidy } \\
\text { delivery mechanism } \\
\text { - Can be funded by cross-subsidy or } \\
\text { the government }\end{array}$ & $\begin{array}{l}\text { Imperfect targeting: May benefit wealthy } \\
\text { customers (who consume little, e.g. at } 2^{\text {nd }} \\
\text { properties) } \\
\text { - Can penalize poor households with shared } \\
\text { connections and/or large families }\end{array}$ \\
\hline $\begin{array}{l}\text { Earmarked } \\
\text { cash subsidy } \\
\text { (vouchers) }\end{array}$ & $\begin{array}{l}\text { - Does not distort prices for the } \\
\text { service }\end{array}$ & $\begin{array}{l}\text { - May be difficult to administer (requires } \\
\text { printing and distribution of vouchers) } \\
\text { - Costly to monitor (would require measures to } \\
\text { ensure that no counterfeit vouchers are made } \\
\text { or used) }\end{array}$ \\
\hline
\end{tabular}

3.42. Cash transfers and voucher schemes have considerably higher targeting efficiency than indirect delivery. Figure 31 shows a comparison of incidence of benefit and costs to the government budget for providing cash transfers to the bottom quintile versus subsidizing service providers. It is based on consumption data from 2012. 
Figure 31. Incidence of Benefit Graph (illustration)

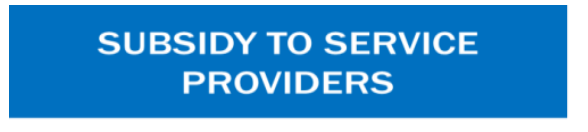

SUBSIDY VIA FAMILY

BENEFITS PROGRAM
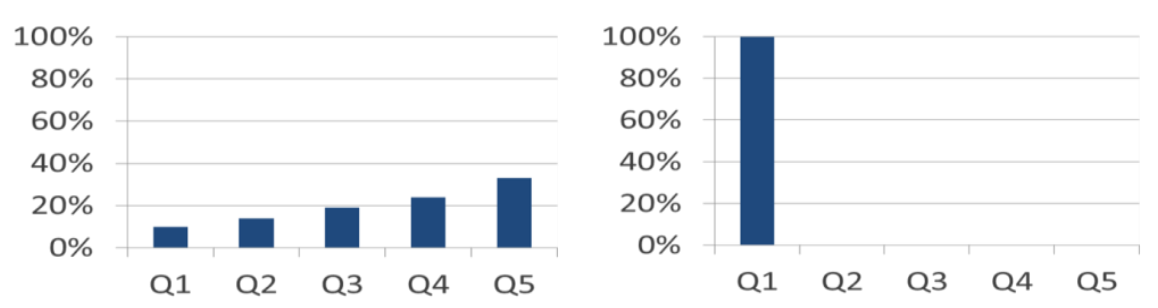

Source: ILSS, NSS.

3.43. As illustrated in Figure 31, the incidence of benefit and targeting efficiency of subsidies delivered through the FBP as cash transfers to customers is much higher than would be expected with indirect transfers to service providers. When subsidies are administered directly to service providers, customers are subsidized on a per consumption level, so customers who consume more receive a greater portion of the subsidy. According to consumption records from 2012, when subsidies are transferred directly to service providers, customers in the $5^{\text {th }}$ quintile receive 330 percent of the subsidies provided to the $1^{\text {st }}$ quintile.

3.44. The administrative cost and burden of this subsidization option is remarkably low, because the FBP has already developed a successful program to target vulnerable utility customers and has in place a mechanism to deliver cash transfers. It takes less than two months for eligible customers who apply to the program to begin receiving benefits. For its advantages in targeting efficiency and administrative costs, it is recommended that cash transfers be used to subsidize vulnerable customers. 


\section{Annex 1: Debt Sustainability Analysis}

1. Debt sustainability analysis (DSA) based on the baseline medium-term projections suggests that Armenia's public debt remains sustainable, although risks are elevated; in particular, external debt is a significant source of vulnerability, and the repayment of the 2013 and 2015 Eurobonds in 2020 and 2025 increase sharply the government's financing needs. Alternative scenarios and stress tests indicate that an adverse growth shock would have the largest impact on debt dynamics and government financing needs.

2. The overall (public and private) external debt increased significantly from 71.1 percent of GDP in 2014 to 84.3 percent in 2015 largely because of the exchange rate depreciation. However, external debt is likely to decline to 78 percent by 2021 , primarily attributable to the fall in the current account deficit. External debt remains sensitive to shocks in growth, non-interest current account and real exchange rate depreciation. The large share of concessional debt in the country's external debt stock however provides cushion to interest rate shocks.

3. The public debt is projected to increase to 54 percent of GDP in 2017, before it starts declining. However, it is likely to remain above 50 percent of GDP over the medium term. Alternative scenarios and stress tests indicate that an adverse growth shock would have the largest impact on debt dynamics and government financing needs. The repayment of Eurobonds in 2020 and 2025 would also sharply increase the government's financing needs. Nearly 85 percent of the public debt is denominated in foreign currency and this heightens foreign exchange risks (Table A1.1).

4. The main vulnerabilities are associated with external public debt. The high share of FX debt and debt held by non-residents is an important risk factor for fiscal sustainability. A further significant depreciation of the exchange rate would deteriorate the debt outlook as indicated by the stress test. However, this risk is mitigated by the fact that over 90 percent of the debt is long-term, mostly provided by official creditors, and at fixed interest rates.

5. Debt dynamics deteriorate under a scenario based on a constant primary balance. The paths of public debt and gross financing needs deviate significantly from the baseline under a constant primary balance scenario; the debt ratio approaches 65 percent and financing needs rise to 18 percent of GDP in 2020, underscoring the importance of fiscal adjustment. Under a scenario where key variables are at their historical averages, the debt dynamics are very close to the baseline but the financing needs increase more noticeably.

6. Stress tests suggest that real GDP growth shocks have the largest impact on debt indicators. An adverse shock to growth, whereby real GDP contracts by 6.1 percent and 5.5 
percent in 2016 and 2017, respectively, causes public debt to increase to over 70 percent of GDP, and public gross financing needs reach 13 percent of GDP by 2017. This scenario, however, is based on historical GDP growth, which has been characterized by quite high volatility, and shocks of such magnitude are relatively unlikely to materialize.

7. Analysis reveals that debt remains sustainable but risks have increased. To stabilize and eventually reduce the public debt level, fiscal consolidation should start as early as 2016 and focus on revenue increases - addressing tax policy and revenue administration gaps - rather than on spending cuts to protect growth-enhancing social and capital expenditures. In light of the significant uncertainty surrounding projections and the forthcoming sizeable external debt payments at the end of the projection horizon, a prudent debt management policy is needed to ensure that the financing needs of the government are met at minimum cost.

Table A1.1: Debt Sustainability Analysis

\begin{tabular}{lrrrrrrrr}
\hline & 2011 & 2012 & 2013 & 2014 & 2015 & $2016 \mathrm{p}$ & $2017 \mathrm{p}$ & $2018 \mathrm{p}$ \\
\cline { 2 - 8 } & \multicolumn{1}{c}{ Actuals } \\
\cline { 2 - 8 } & \multicolumn{7}{c}{ Projections } \\
Total public sector debt & 42.0 & 41.2 & 40.8 & 43.5 & 48.7 & 52.4 & 54.0 & 53.9 \\
External public sector debt & 36.5 & 35.3 & 34.8 & 37.5 & 42.3 & 45.6 & 46.5 & 46.4 \\
Domestic public sector debt & 5.5 & 5.9 & 6.0 & 6.0 & 6.4 & 6.8 & 7.5 & 7.5 \\
Gross external debt & 71.5 & 70.2 & 78.1 & 71.1 & 84.3 & 86.5 & 86.5 & 84.3 \\
\hline
\end{tabular}

Source: IMF debt sustainability analysis. 


\section{Annex 2: Underlying Assumptions of Financial Models and Forecasts of State-Owned Power Companies}

\section{A. Electricity End-User Tariffs}

Electricity end-user tariffs for 2014-2015 are based on approved tariff calculations provided by PSRC. For the forecast period of 2016-2017, tariffs were set to ensure cost recovery given the expected changes in tariff covered costs/expenses under Rate of Return (Cost +) methodology. Material, maintenance, and salary expenses were assumed to increase at estimated rates of inflation as per the IMF World Economic Outlook, April 2015. Debt service expenses were forecast using the terms of outstanding IFI and commercial loans and committed donor funding under effective energy sector projects and projects in the pipeline. Forecast depreciation expenses were determined using average historical depreciation rates and planned capital expenditures. All other operating expenses, except for fuel costs of YTPP and ANPP, were assumed to remain at the 2014 level.

Table A1.2: Electricity End-user Tariffs

\begin{tabular}{|l|c|c|c|c|c|c|c|c|c|c|}
\hline & Unit & 2011 & 2012 & 2013 & 2014 & 2015 & 2016 & 2017 & 2018 & 2019 \\
\hline YTPP & AMD $/ \mathrm{kWh}$ & 11.66 & 5.33 & 20.07 & 29.13 & 27.83 & 28.54 & 29.05 & 29.39 & 29.68 \\
\hline $\begin{array}{l}\text { HVE } \\
\text { N }\end{array}$ & AMD $/ \mathrm{kWh}$ & $\mathbf{0 . 8 3}$ & $\mathbf{0 . 3 3}$ & 1.07 & 1.36 & 0.86 & 0.71 & 0.72 & 0.80 & 0.85 \\
\hline ANPP & AMD $/ \mathrm{kWh}$ & $\mathbf{8 . 4 3}$ & $\mathbf{9 . 6 6}$ & 10.83 & 11.41 & 10.38 & 10.48 & 10.76 & 11.04 & 11.35 \\
\hline
\end{tabular}

Table A2.1: Inflation Rate Forecast, as per the IMF World Economic Outlook, April 2015

\begin{tabular}{|c|c|c|c|c|c|}
\hline & 2015 & 2016 & 2017 & 2018 & 2019 \\
\hline $\begin{array}{ll}\text { Inflation } & \text { rate } \\
(\%) & \\
\end{array}$ & 6.40 & 4.00 & 4.00 & 4.00 & 4.00 \\
\hline
\end{tabular}

Cost of fuel is a significant cost item for both YTPP and ANPP. For Yerevan, it is assumed to be affected by forecast annual increase in the cost of Russian gas and the share of the latter in the total fuel cost of the plant (see Table A2.4). Fuel costs of ANPP are assumed to increase at estimated rates of inflation as per the IMF World Economic Outlook, April 2015. 
Table A2.2: HVEN Borrowing Schedule

\begin{tabular}{|c|c|c|c|c|c|c|}
\hline & 2014 & 2015 & 2016 & 2017 & 2018 & 2019 \\
\hline \multicolumn{7}{|l|}{$\begin{array}{l}\text { WB \$39 million Electricity Supply } \\
\text { Reliability Project (ESRP) } \\
\text { (effective since Nov. 2011) }\end{array}$} \\
\hline Disbursement, \% of loan amount & $10 \%$ & $30 \%$ & $35 \%$ & & & \\
\hline Disbursement, $\$$ million & 3.9 & 11.7 & 13.65 & & & \\
\hline \multicolumn{7}{|l|}{$\begin{array}{l}\text { WB } \$ 40 \text { million ESRP Additional } \\
\text { Financing (eff. Dec. 2014) }\end{array}$} \\
\hline Disbursement, \% of loan amount & $0 \%$ & $20 \%$ & $35 \%$ & $40 \%$ & $5 \%$ & \\
\hline Disbursement, $\$$ million & - & 8 & 14 & 16 & 2 & \\
\hline \multicolumn{7}{|l|}{$\begin{array}{l}\text { WB \$28 million ETNIP (effective } \\
\text { May 2014) }\end{array}$} \\
\hline Disbursement, $\%$ of loan amount & $0 \%$ & $5 \%$ & $20 \%$ & $30 \%$ & $35 \%$ & $10 \%$ \\
\hline Disbursement, $\$$ million & - & 1.4 & 5.6 & 8.4 & 9.8 & 2.8 \\
\hline \multicolumn{7}{|l|}{$\begin{array}{l}\text { ADB } \$ 37 \text { million loan (effective } \\
\text { Dec. 2014) }\end{array}$} \\
\hline Disbursement, $\%$ of loan amount & $0 \%$ & $15 \%$ & $25 \%$ & $35 \%$ & $25 \%$ & \\
\hline Disbursement, $\$$ million & - & 5.55 & 9.25 & 12.95 & 9.25 & \\
\hline \multicolumn{7}{|l|}{$\begin{array}{l}\text { KfW Euro } 105 \text { million loan } \\
\text { (effective Dec. 2015) }\end{array}$} \\
\hline Disbursement, $\%$ of loan amount & $0 \%$ & $0 \%$ & $20 \%$ & $35 \%$ & $40 \%$ & $5 \%$ \\
\hline Disbursement, EUR million & - & - & 21 & 36.75 & 42 & 5.25 \\
\hline
\end{tabular}


Table A2.3: Cost of Fuel Assumptions for YTPP

\begin{tabular}{|l|r|r|r|r|r|r|}
\hline & $\mathbf{2 0 1 4}$ & $\mathbf{2 0 1 5}$ & $\mathbf{2 0 1 6}$ & $\mathbf{2 0 1 7}$ & $\mathbf{2 0 1 8}$ & $\mathbf{2 0 1 9}$ \\
\hline $\begin{array}{l}\text { Annual increase in the Russian gas } \\
\text { cost for YTPP }(\%)\end{array}$ & 2.9 & 3.8 & 6.6 & 6.2 & 6.2 & 6.2 \\
\hline $\begin{array}{l}\text { Share of Russian gas cost in the total } \\
\text { fuel cost }(\%)\end{array}$ & 40 & 40 & 40 & 40 & 25 & 25 \\
\hline
\end{tabular}

\section{B. Working Capital}

Inventory levels, receivables, and payables are forecast using corresponding turnover ratios, which were assumed to remain at the level of 2014. 


\section{Annex 3: Tariff Reform and Subsidies ${ }^{25}$}

\section{A. Tariff Reform Overview}

Utility tariff reform is often necessary to increase access, quality, and reliability of services, but it can disproportionately impact the poor and lead to social unrest if mitigation measures are not put in place. Successful reform efforts typically do the following:

- Provide highly targeted subsidies for vulnerable households;

- Gradually phase in cost recovery tariffs;

- Conduct transparent and sustained communication with the public.

\section{B. Subsidy Delivery}

An increase in utility tariffs will usually have a disproportionate impact on poor households' budgets. Designing a subsidy regime requires decisions about: (1) how to identify the poor; (2) how to deliver the subsidy; (3) when to deliver the subsidy; and (4) how to fund the subsidy. Options for each of these decisions are described and evaluated in the subsections below. This section describes different approaches to each step.

\section{How to Identify the Poor}

\section{Poor customers are typically identified by:}

- Their consumption level. So-called "lifeline tariffs" are tariffs which are lower for certain customers based on the amount of household consumption. These tariffs are generally applied to the initial block of consumption, called the basic need or subsistence consumption. Under inclining block tariff structures, this lower rate can either be included for all customers for their first block, or only be applied to those customers that use less than the first block set as subsistence consumption). A variation on the lifeline tariff is to waive or partially waive, or to provide a credit or partial credit for the fixed monthly customer charge for a targeted group of customers.

- Assumptions about their income levels. In some countries, customers receive compensation for the share of utility expenditures that exceed a notional "burden limit," determined as a given percentage of monthly household income. In Ukraine, for example, the government provided discounts to households that spent more than 20 percent of monthly income on utilities). Income levels are typically determined by:

\footnotetext{
${ }^{25}$ From: Armenia Water Tariff Study, World Bank, 2015.
} 
Household budget, income survey data, or other information collected by the government (e.g., existing social support programs)

- Other normative assumptions (e.g., type of housing)

- Documents providing verification of income

- Demand for subsidies. In some countries, customers must submit an application for consideration and must provide verification of income.

Poverty in Armenia has been assessed since 1996 using a consumption aggregate which includes the monetary value of a basket of food and non-food goods adjusted for regional and seasonal price differences. There are three poverty levels in Armenia: poor, very poor, and extremely poor. These levels are demarcated by poverty lines. Baseline line data is updated once every few years. The most recent update occurred in 2009. In 2012, 32.4 percent of households in Armenia lived below the poverty line. ${ }^{26}$ However, the Family Benefit Program (FBP) - the largest social transfer program in Armenia - uses a means test on income and a vulnerability scoring formula to identify and allocate social transfers to the poor. This formula allows the GoA to rank applicants, giving preference to single mothers, orphans, families with many children, and the differently abled. ${ }^{27}$

\section{How to Deliver the Subsidy}

Subsidies can be delivered directly to customers through cash transfers or vouchers. They can also be delivered indirectly, e.g., through discounts on customers' energy bills. However, there is often a trade-off between administrative costs and targeting efficiency. Options to reach target populations most effectively often have high administrative or monitoring costs. The section below describes a few ways in which subsidies can be delivered to poor households.

- Cash transfers allow a government to increase consumers' purchasing power by supplementing the household income with allocations of money. The money may be intended for a particular purpose, but customers are not required to use it in a specific way. The effectiveness of targeting the poor with cash transfer schemes depends on the institutional capacity to reach the intended beneficiaries.

- Voucher schemes, or near-cash transfers to households, also aim to increase consumers' purchasing power. Unlike cash, which can be used to buy anything, vouchers are designated for a specific purpose, such as the purchase of a given utility. Voucher programs are low cost compared to universal subsidy programs. However, the administrative costs of voucher programs tend to be higher than those of cash transfer programs. The development and distribution of vouchers is inherently more complicated than the distribution of cash.

\footnotetext{
${ }^{26}$ In 2012, households that spent less than AMD 37,044 per month were considered poor.

${ }^{27}$ Ersado and Levin. 2011.
} 
- Indirect delivery of the subsidy means subsidizing the utility companies so that they are able to discount rates. This subsidy can be roughly targeted, such as through a lifeline tariff, or untargeted, such as when all end-user tariffs are set below cost-recovery levels.

- Lifeline tariffs can be used to ensure that all consumers can afford a subsistence level of utility consumption. Implementation of a lifeline tariff involves a discount on the first portion of consumption, estimated at subsistence levels, while all subsequent consumption is billed at the higher rate. Another option is to charge all consumption at the highest consumption block customers enter during a billing period. This would mean that customers only benefit from the lifeline rate if they keep their consumption within the first block.

Cash transfer schemes are generally recognized as a best practice if sufficient institutional capacity exists for targeting and delivery. Armenia fortunately has high institutional capacity to implement a cash transfer scheme through the FBP, which has been shown to have high targeting efficiency.

\section{When to Deliver the Subsidy}

Indirect subsidies to utilities can be delivered in lump sums tied to budgeting cycles. Subsidies to customers through the FBP can be delivered on a monthly or bi-monthly basis directly to customers as cash transfers, using the existing system employed by the FBP program.

\section{How to Fund the Subsidy}

Subsidies may be funded by: (1) direct transfer from the government; (2) through cross-subsidies from other customer classes (inter-class subsidies); or (3) within a customer class (intra-class subsidies). The advantage of a cross-subsidy is that it avoids using government funds. The disadvantage is that it distorts prices, which affects consumption by the customer classes that fund and receive the cross-subsidy.

Existing social protection programs in Armenia are some of the best targeted programs in the ECA region. ${ }^{28}$ The Family Benefit Program (FBP) is well suited to distribute subsidies in the form of credits equal to the monthly average utility consumption of poor households multiplied by the difference between the new and affordable tariff.

${ }^{28}$ Ersado and Levin. 2011. 


\section{References}

Abiad, Abdul, Davide Furceri, and Petia Topalova. 2015, "The Macroeconomic Effects of Public Investment: Evidence from Advanced Economies," IMF working paper, WP/15/95, International Monetary Fund, Washington, DC.

Aschauer, David Alan. 1989. "Is public expenditure productive?" Journal of Monetary Economics, Elsevier, vol. 23(2): 177-200, March.

Barro, Robert J. 1990. "Government Spending in a Simple Model of Endogenous Growth," Journal of Political Economy, University of Chicago Press, vol. 98(5): S103-26 (October).

Bom, Pedro R.D., \& Jenny E. Ligthart. 2014. "What Have We Learned From Three Decades Of Research On the Productivity of Public Capital?" Journal of Economic Surveys, Wiley Blackwell, vol. 28(5): 889-916 (December).

Eden, Maya, \& Aart Kraay. 2014. “'Crowding in' and the returns to government investment in low-income countries," Policy Research Working Paper Series 6781, The World Bank, Washington, DC.

Ersado, Lire, and Victoria Levin. 2011. "Armenia - Social assistance programs and work disincentives." World Bank, Washington, DC.

Freinkman, Lev, Gohar Gyulumyan, and Artak Kyurumyan. 2003. "Quasi-Fiscal Activities, Hidden Government Subsidies, and Fiscal Adjustment in Armenia." Working Paper No. 16, World Bank, Washington, DC.

Gupta, Sanjeev, Benedict Clements, Emanuele Baldacci, \& Carlos Mulas-Granados. 2005. "Fiscal policy, expenditure composition, and growth in low-income countries," Journal of International Money and Finance, Elsevier, vol. 24(3): 441-463 (April).IMF, 2014. "WORLD ECONOMIC OUTLOOK (WEO) Legacies, Clouds, Uncertainties," International Monetary Fund, Washington, DC, 2014 (October).

IMF, 2015. "Republic of Armenia: Selected Issues," IMF Country Report No. 15/66, International Monetary Fund, Washington, DC, 2015 (March).

Kneller, Richard, Michael F. Bleaney, \& Norman Gemmell. 1999. "Fiscal policy and growth: evidence from OECD countries," Journal of Public Economics, Elsevier, vol. 74(2): 171-190 (November).

World Bank. 2012. Fiscal Consolidation and Recovery in Armenia: Impact of the Global Crisis on a Small Open Economy. World Bank, Washington, DC. 
World Bank. 2013 "Country Partnership Strategy for the Republic of Armenia, FY2014FY2017." Report Number 81647-AM, October 9, 2013, World Bank, Washington, DC.

World Bank. 2014. Republic of Armenia Public Expenditure Review: Expanding the Fiscal

Envelope. Poverty Reduction and Economic Management Unit, Europe and Central Asia Region, World Bank, Washington, DC. 